\title{
Analysing Energy Innovation Portfolios from a Systemic
}

\section{Perspective}

\section{Authors}

Yeong Jae Kim ${ }^{1,2 *}$

Charlie Wilson ${ }^{2,3}$

\section{Affiliations}

${ }^{1}$ RFF-CMCC European Institute on Economics and the Environment (EIEE)

Via Bergognone 34, 20144 Milano, Italy

* Corresponding author: yeongjae.kim@eiee.org

${ }^{2}$ Tyndall Centre for Climate Change Research, University of East Anglia, UK

School of Environmental Sciences, University of East Anglia, Norwich, NR4 7TJ, UK

${ }^{3}$ International Institute for Applied Systems Analysis, Laxenburg, Austria

Schlossplatz 1, A-2361 Laxenburg, Austria

Charlie.wilson@uea.ac.uk

Post-print of article published in Energy Policy.

Please cite: Kim, Y.J. and C. Wilson (2019). "Analysing energy innovation portfolios from a systemic perspective." Energy Policy 134: 110942.

https://doi.org/10.1016/j.enpol.2019.110942 


\title{
Analysing Energy Innovation Portfolios from a Systemic
}

\section{Perspective}

\begin{abstract}
A systemic perspective on energy innovation is required to design effective portfolios of directed innovation activity. We contribute a standardised set of technology-specific indicators which describe processes throughout the energy technology innovation system, ranging from patents and publications to policy mixes, collaborative activity, and market share. Using these indicators, we then conceptualise and develop benchmark tests for three portfolio design criteria: balance, consistency, and alignment. Portfolio balance refers to the relative emphasis on specific technologies. Portfolio consistency refers to the relative emphasis on related innovation system processes. Portfolio alignment refers to the relative emphasis on innovation system processes for delivering targeted outcomes. We demonstrate the application of these benchmark tests using data for the EU's Strategic Energy Technology (SET) Plan which spans six technology fields. We find the SET Plan portfolio generally performs well particularly in areas over which portfolio managers have direct influence such as RD\&D funding. However we also identify potential areas of imbalance, inconsistency, and misalignment which warrant further attention and potential redress by portfolio managers. Overall, we show how energy innovation portfolios can be analysed from a systemic perspective using a replicable, standardised set of measures of diverse innovation system processes.
\end{abstract}

\section{Keywords}

Energy innovation system; Indicator; Portfolio; EU SET Plan

\section{Acronyms}

CCS Carbon capture and storage

RD\&D Research, development and demonstration 
SET Plan Strategic Energy Technology Plan

\section{Highlights}

- Comprehensive set of technology-specific indicators for measuring innovation system processes

- Design criteria for evaluating innovation portfolios

- Policy insights on energy research and innovation portfolio design

- Evaluation of the EU's energy innovation portfolio for balance, consistency \& alignment 


\section{Introduction}

Energy innovation outcomes are irreducibly uncertain, dependent on technological progress as well as external developments in markets and institutional environments (Grubler et al., 2012). The scale and scope of energy-system challenges require a correspondingly broad strategy to energy innovation across multiple sectors, applications, conversion-chains, and end-uses. Innovation efforts directed towards public policy goals like decarbonisation can target specific technologies, but the capacity of policymakers to 'pick winners' is fraught with political, informational, and procedural difficulty (Nemet et al., 2017).

Innovation portfolio design has traditionally been concerned with the mix of technologies or investment targets. Portfolio theory was originally developed to identify the optimal mix of financial assets to minimise risk (Markowitz, 1952, 1959). Similar approaches have been applied to energy innovation portfolios exposed to technological, market, and other systemic risks (Fuss \& Szolgayová, 2010).

In addition to deciding the composition of technologies in an innovation portfolio, portfolio managers must decide how to allocate their efforts to influence innovation processes and outcomes. A systemic perspective on innovation emphasises the influence of wider institutional, market, and policy conditions on the innovation lifecycle, the coordination and multi-stakeholder governance of innovation processes, and enabling frameworks or conditions to direct innovation activity (OECD, 2015). These and other innovation system processes may be more or less amenable to influence by policymakers seeking to 'direct' innovation efforts (OECD, 2015; Wieczorek \& Hekkert, 2012).

Innovation portfolios therefore comprise not just different technologies or investments, but also different innovation system processes. A generalisable insight from the literature on innovation systems is that omissions or weaknesses in specific processes reduce the overall effectiveness of the system (Bergek et al., 2008). Innovation systems which are strongly weighted towards specific processes (e.g., RD\&D funding) at the expense of others (e.g., market feedback) are less likely to deliver on desired outcomes (Grubler \& Wilson, 2014b). Similarly, a diverse policy mix is more 
effective than a singular reliance on specific instruments, particularly given the systemic change necessary for energy system transformation (Kern \& Howlett, 2009).

In this paper we draw on literature to argue that balance across technologies, consistency between innovation system proceses, and alignment with intended outcomes are three desirable characteristics for energy innovation portfolio design (Table 1). However there are no standardised tests in the innovation systems literature to assess these three normative criteria across any innovation portfolio. The research question we address is: How can energy innovation portfolios be tested for balance, consistency and alignment from a systemic perspective? Our contributions are twofold. First, we develop a comprehensive set of technology-specific indicators characterising the innovation system which can be applied to any innovation portfolio. Second, we develop and apply three simple benchmark tests as indicative diagnostics of whether innovation portfolios are balanced, consistent and aligned. These benchmark tests are not designed to provide definitive assessments, but rather to draw portfolio managers' attention to areas of potential concern worthy of further investigation. We use one of the world's largest energy innovation portfolios - the EU's Strategic Energy Technology (SET) Plan - to show the value of our approach, but emphasise that both the indicators and our simple benchmark tests are designed to be generalisable to any energy innovation portfolio.

Table 1. Criteria for designing energy innovation portfolios from a systemic perspective.

\begin{tabular}{|l|l|l|l|}
\hline & Balance & Consistency & Alignment \\
\hline Rationale & Diversify technology risk & $\begin{array}{l}\text { Coordinate innovation } \\
\text { system processes }\end{array}$ & $\begin{array}{l}\text { Direct innovation system } \\
\text { towards desired } \\
\text { outcomes }\end{array}$ \\
\hline Cautionary tale & Avoid picking winners & $\begin{array}{l}\text { Avoid singular RD\&D- } \\
\text { led strategies }\end{array}$ & $\begin{array}{l}\text { Avoid } \text { ad hoc targets and } \\
\text { pork-barrel politics }\end{array}$ \\
\hline $\begin{array}{l}\text { Analytical } \\
\text { Approach }\end{array}$ & $\begin{array}{l}\text { Analyse composition of } \\
\text { technology portfolio }\end{array}$ & $\begin{array}{l}\text { Analyse omissions, } \\
\text { tensions \& weaknesses } \\
\text { in innovation system }\end{array}$ & $\begin{array}{l}\text { Analyse targets, stated } \\
\text { outcomes \& innovation } \\
\text { outputs }\end{array}$ \\
\hline $\begin{array}{l}\text { Simple } \\
\text { benchmark test } *\end{array}$ & $\begin{array}{l}\text { Similar relative shares of } \\
\text { technologies across innovation } \\
\text { system processes }\end{array}$ & $\begin{array}{l}\text { Similar relative shares of } \\
\text { related innovation } \\
\text { system processes across } \\
\text { technologies }\end{array}$ & $\begin{array}{l}\text { Similar relative shares of } \\
\text { outputs and outcomes } \\
\text { across technologies }\end{array}$ \\
\hline
\end{tabular}

* In the absence of clearly-articulated objectives for specific portfolios against which performance can be tested.

The rest of this paper is organized as follows. First, we review relevant literature on innovation portfolios from a systemic perspective and introduce the energy technology innovation system (ETIS) framework. Second, we define a comprehensive set of indicators to measure the different dimensions 
and processes in the innovation system. Third, we introduce the EU SET Plan as our case study innovation portfolio, and explain our methods for collecting data measuring the indicators for the EU's SET Plan. Fourth, we apply our portfolio design criteria to evaluate the balance, consistency and alignment of the EU's SET Plan and discuss key results. Finally, we explore the policy implications of our analysis for the SET Plan portfolio managers.

\section{Literature Review}

\subsection{Analytical frameworks for innovation systems}

Analytical frameworks with different emphases have been proposed for evaluating the performance of innovation systems, including those related to energy technologies. The National Innovation System (NIS) framework explains the flow of people and firms within institutions at the national level (Freeman, 1987; Freeman, 1995; Lundvall, 1992; Nelson, 1993). Using a variant of the NIS framework, the annual Global Innovation Index compiles and analyses quantitative metrics of innovation performance at the country level, capturing a wide range of institutional, human, infrastructural, market, and business factors that influence the efficiency with which countries convert innovation inputs into outputs (Cornell University et al., 2018).

Other innovation system frameworks apply to specific technologies and emphasise either structural elements or functional dynamics (Jacobsson et al., 2017). The Technology Innovation System (TIS) literature analyses the actors, institutions, and networks that comprise structural elements of innovation systems explaining the emergence and development of new technologies (Carlsson \& Stankiewicz, 1991; Carlsson \& Jacobsson, 1994). TIS scholars have tended to focus on specific technologies within a country (Hudson et al., 2011; Jacobsson \& Karltorp, 2013; Hannon et al., 2017). The TIS has also typically been applied to the early formative phase of an innovation system rather than its full lifecycle through growth, maturity and senescence (Markard, 2018).

The Functions of Innovation Systems (FIS) literature shifts the emphasis onto a discrete set of functional characteristics of innovation system performance (Hekkert \& Negro, 2009; Bergek et al., 2008). These functions describe how well actors and institutions perform entrepreneurial activities, 
knowledge development and dissemination, the guidance of search, market formation, resource mobilisation, and the creation of legitimacy (Hekkert et al., 2007). More recent literature has sought to reconcile these structural and functional perspectives, recognising their close inter-dependence (Wieczorek \& Hekkert, 2012).

\subsection{The Energy Technology Innovation System (ETIS) framework}

The TIS and FIS frameworks enable powerful narrative accounts of technology-specific innovation systems emphasising contingencies and context-dependence. However their key elements whether structural or functional - are hard to measure in a standardised way across technologies and adoption contexts. Consequently empirical studies using TIS and FIS frameworks focus on specific technologies rather than innovation portfolios. Portfolio-based analysis requires an analytical framework which is both technology-specific and generalisable to portfolios of technologies using standardised measures.

Drawing on insights from both the TIS and FIS literature, the energy technology innovation system (ETIS) framework is useful for analysing energy innovation from a systems perspective in a generalisable way (Grubler \& Wilson, 2014b). The ETIS framework was originally developed for the Global Energy Assessment (Gallagher et al., 2012; Grubler et al., 2012) based on in-depth analysis of 20 historical case studies of relative success and failure in energy innovation (Grubler \& Wilson, 2014b). We summarise the main rationale and explanation for the ETIS framework here and in the appendices, and refer the reader to these source texts for further detail and empirical justification.

The ETIS framework characterises how different elements of the innovation system combine to give rise to successful innovation outcomes (Gallagher et al., 2012; Grubler \& Wilson, 2014b). The ETIS framework focuses on observable processes associated empirically with relative success or failure specific to energy technologies. In terms of application, the ETIS framework was designed as a tractable analytical tool for identifying the strengths and weaknesses of any given energy innovation system using a standardised set of dimensions and processes applicable to any technology (Grubler et al., 2012; Grubler \& Wilson, 2014b). 
Figure 1 illustrates the four dimensions of the ETIS framework which provide the context for the familiar innovation lifecycle from research and development through to diffusion (Balconi et al., 2010; Grubb et al., 2017). The knowledge dimension includes processes of knowledge generation, exchange, codification as well as depreciation. The resources \& policies dimension emphasises the importance of resource mobilisation in the form of finances, enabling policies, and innovators. The actors \& networks dimension includes institutional conditions such as actor networks and heterogeneity. The users \& markets dimension is concerned with consumers, market feedback and expectations. Detailed explanations of all these dimensions and innovation system processes are provided in Appendix A.

Compared to other innovation system frameworks, the ETIS framework places greater attention on the role of end users and market adoption, and frames innovation system processes in terms of both accumulating and depreciating capacity to generate and codify knowledge, to mobilise resources and institutional support, to facilitate actor networks and knowledge exchange, and to learn from users in market environments.

Innovation system processes associated with each dimension of the ETIS framework collectively generate successful innovation outcomes (Grubler \& Wilson, 2014b). However, the innovation system is a complex, dynamic system characterised by iterative processes and feedbacks. Consequently innovation system frameworks like ETIS - as with the national, technological and functional frameworks (NIS, TIS, FIS) considered above - cannot be represented in a single integrative model explaining deterministically how inputs generate outputs.

First, inputs can not always be clearly distinguished from outputs. As an example, knowledge generated by installing and using innovations (input) causes learning-by-doing and performance improvements (output) which leads to more knowledge generation (input). Consequently we distinguish directed efforts from outcomes rather than inputs from outputs, as our aim is to an unfolding time dimension rather than a specific causal $\mathrm{x} \rightarrow \mathrm{y}$ (see also Figure 2).

Second, whereas discrete causal mechanisms can be isolated, innovation outputs and outcomes are contingent on system conditions as well as exogenous factors. As an example, R\&D investments 
to generate knowledge causes patent filings, but this process is highly uncertain, dependent on the constellation of innovation actors involved, and responds to the wider intellectual property and trade environment.

Third, many innovation system processes are not observable, and can be measured only through proxy indicators often with scarce data. Multivariate quantitative analysis of innovation invariably emphasises R\&D, patents, publications and prices as variables for which granular time-dependent databases are readily available. Publications like the Global Innovation Index provide additional country-level data on innovation actors, networks, institutions, policies, and funding, but such data are hard to construct for technology-specific analyses (Wilson \& Kim, 2018).

For all these reasons, innovation systems analysis provides insight into specific causal mechanisms within a system which "demonstrates a substantial degree of contingency, heterogeneity, and path-dependence" (Little, 2015, p. 470).

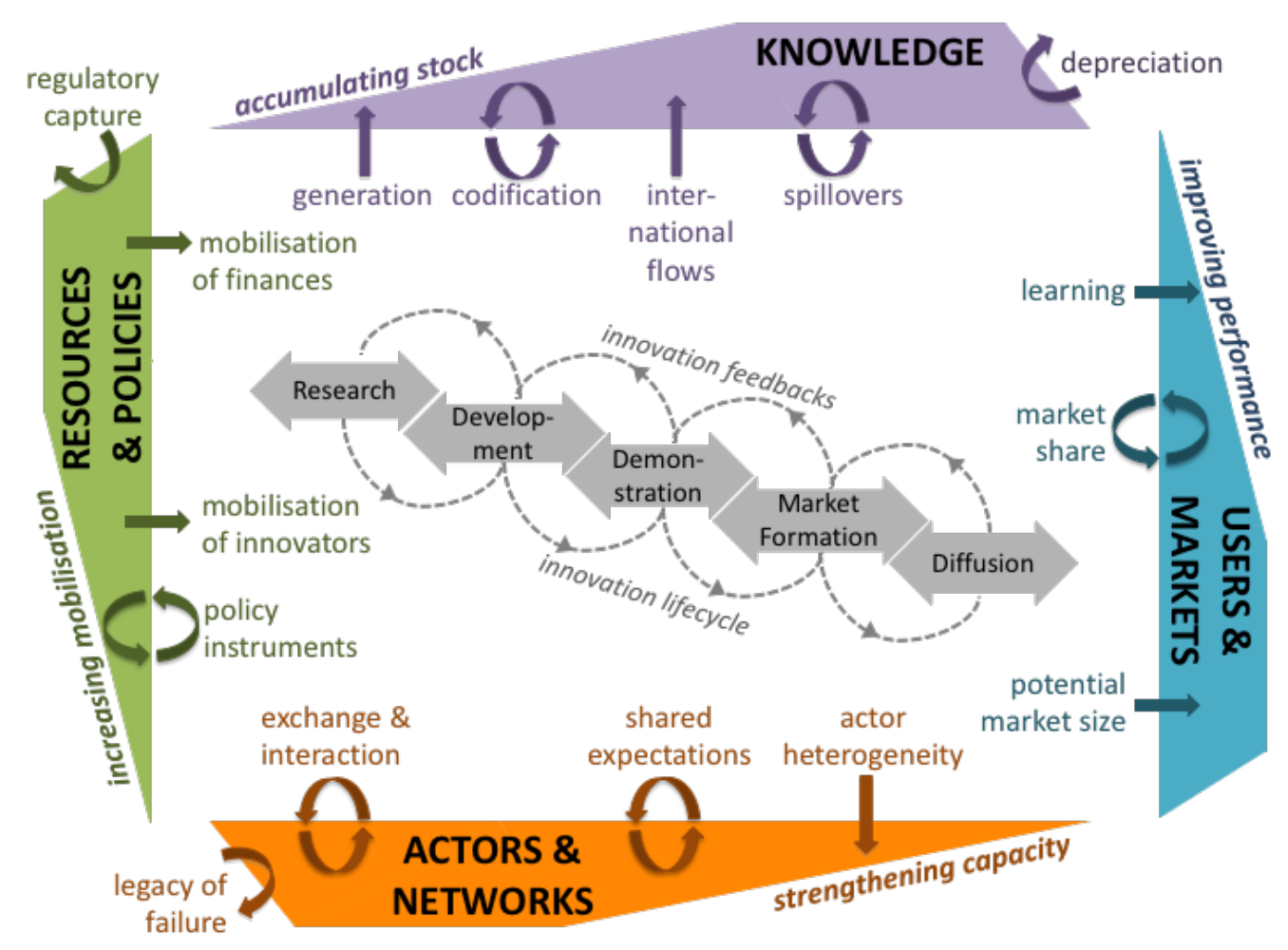

Figure 1. The energy technology innovation system (ETIS) framework. Adapted from: (Grubler \& Wilson, 2014b). 


\subsection{Designing and managing innovation portfolios from a systemic perspective}

As the ETIS framework shows, innovation systems comprise many processes which are more or less amenable to influence by policymakers seeking to 'direct' innovation efforts in response to market, structural and transformational failures (OECD, 2015; Wieczorek \& Hekkert, 2012).

Structural and transformational failures in innovation systems provide a strong rationale for strategic intervention, beyond the need to correct for market failures which result in underinvestment in innovation due to its uncertain distant payoffs (Weber \& Rohracher, 2012). Structural failures blocking successful innovation outcomes include: institutions creating uncertainty; weak knowledge exchange if interactions are limited; poor capabilities for accessing and learning from new knowledge (Wieczorek \& Hekkert, 2012; Woolthuis et al., 2005). Transformational failures include: lack of shared vision and direction; weak market demand and signals from users; lack of policy coordination; lack of monitoring and policy learning (Weber \& Rohracher, 2012).

Certain innovation system processes can - in principle - be directly managed by policymakers, subject to political and other constraints. Examples include allocation of public research, development $\&$ demonstration (RD\&D) budgets and regulatory policy instruments. Policymakers have a relatively high degree of control over the relative emphasis placed on such processes within an innovation system. Other innovation system processes can only be indirectly shaped, facilitated or incentivised by policymakers but not directly managed. Examples include knowledge spillovers through trade and actor interaction through research collaborations. Policymakers can seek to stimulate (or restrict) such processes, but can not directly determine outcomes. Policymakers have a relatively low degree of control over the relative emphasis placed on such processes within an innovation system. Finally, policymakers can systemically influence innovation through strategies, policies, and measures designed to affect overall system conditions (OECD, 2015). Examples include intellectual property protection and training, education and skills development. These broader system conditions may in turn influence many different innovation system processes such as patenting propensity and skilled worker employment. Policymakers have a still lower degree of control over the relative emphasis placed on such processes within an innovation system. 
In sum, innovation portfolios comprise not just multiple technologies, but also multiple innovation system processes which policymakers can direct towards targeted outcomes with greater or lesser degree of direct control. The upper panel [a] of Figure 2 summarises these three axes of an innovation portfolio: across technologies (y-axis in Figure 2); across innovation system processes ( $\mathrm{x}$ axis in Figure 2); and across time from inputs to outputs and targeted outcomes (z-axis in Figure 2).

[a] an innovation portfolio comprising technologies $\left(T_{n}\right)$ and innovation system processes $\left(I_{n}\right)$

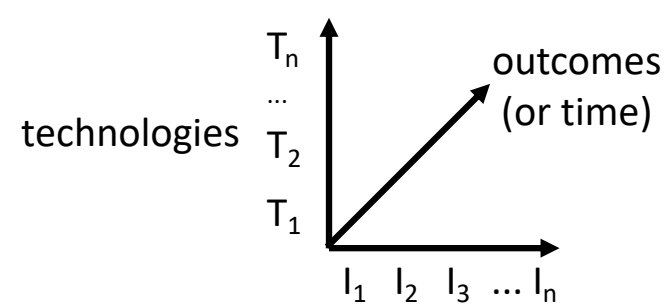

innovation system processes

\section{an illustrative portfolio comprising three technologies and four innovation system processes}

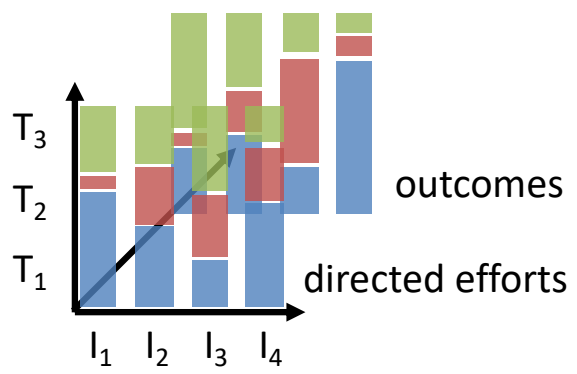

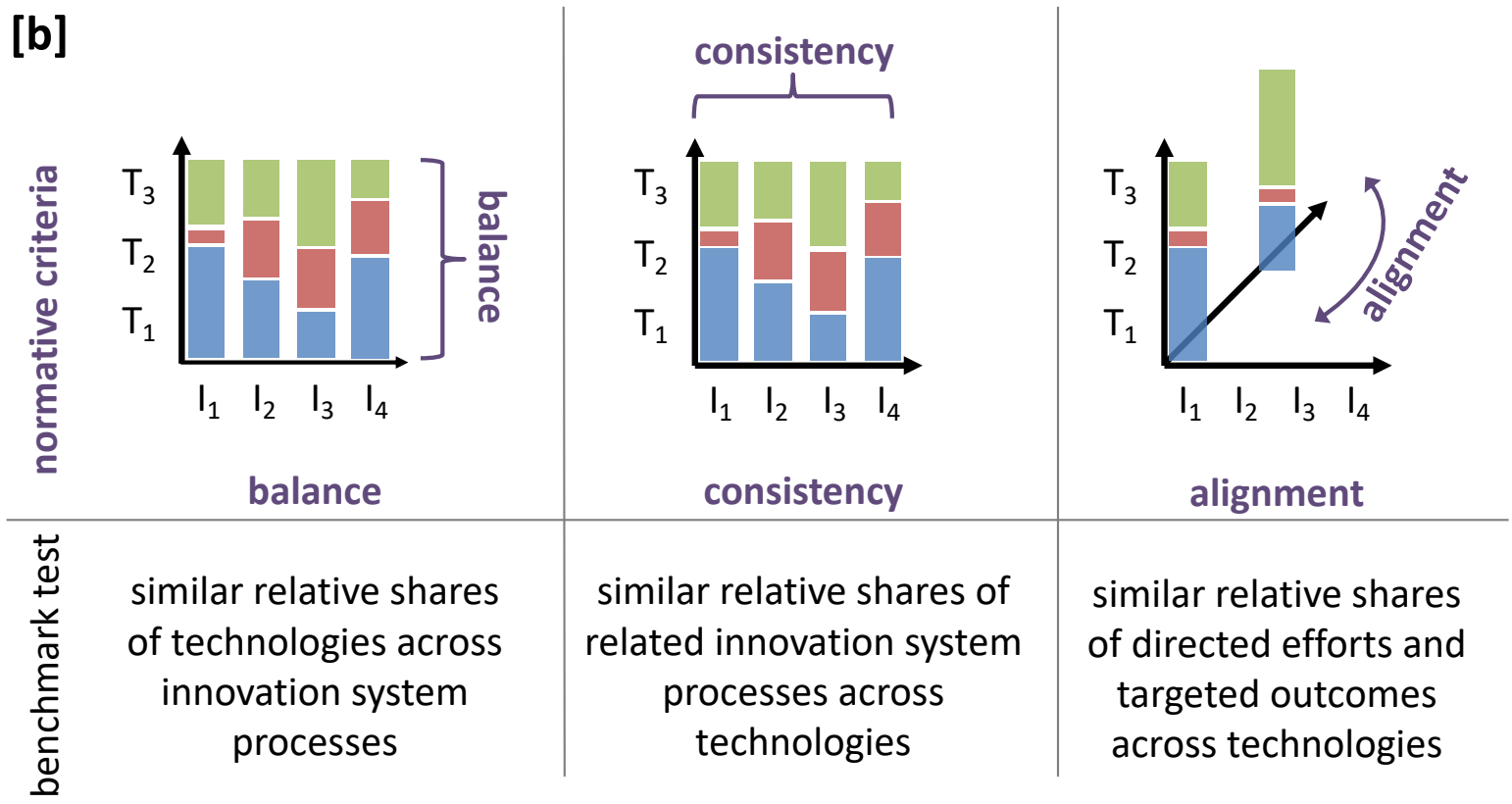

Figure 2. Innovation portfolios from a systemic perspective. Notes: upper panel [a] illustrates an innovation portfolio comprising multiple technologies, innovation system processes, and time steps towards outcomes; lower panel [b] illustrates three normative design criteria - balance, consistency \& alignment - and three simple benchmark tests for each criterion. 
In addition to this descriptive characterisation of the different dimensions to innovation portfolio design, historical analysis of relative success and failures in energy innovation systems supports certain normative criteria: balance, consistency and alignment (Grubler \& Wilson, 2014b).

A balanced innovation portfolio is diversified across the range of technologies which can contribute to desired outcomes (Wilson et al., 2012). Diversification helps manage risks given that innovation outcomes are highly uncertain. In the absence of clearly-articulated objectives for portfolio composition, a simple benchmark test for portfolio balance is a similar emphasis or equal weighting across technology fields (Table 1). For example, one of the key visions of the EU is a diverse portfolio of low-carbon energy technologies for a sustainable green economy (EC, 2007).

A consistent innovation portfolio has diverse innovation system processes working in concert (Bergek et al., 2008; Grubler \& Wilson, 2014a). Consistency implies a coordinated approach to directed innovation efforts and a policy mix responding to the needs of heterogeneous actors and interests (Kern \& Howlett, 2009). For example, a high level of effort to mobilise financial resources in a clear and stable policy environment also requires emphasis on supporting innovation actors and their networks of interaction and knowledge exchange to ensure the necessary human capacity to absorb and effectively use resources. In the absence of technology-specific analysis on innovation system needs and enabling conditions, a simple benchmark test for portfolio consistency is a similar emphasis or equal weighting across innovation system processes for any given technology (Table 1).

An aligned energy innovation portfolio has inputs directed towards outputs and desired outcomes throughout the stages of the innovation lifecycle, from RD\&D to market formation and diffusion. Misalignment creates long-term uncertainty and unclear signals to innovators, can delay or stagnate the development and diffusion of innovations, and can reinforce transitional difficulties in the 'valley of death' between demonstration and commercialisation (Hekkert et al., 2007; Weyant, 2011). A common example of misalignment is between policy efforts to improve energy efficiency (e.g., through performance standards) while simultaneously subsidising the price of retail fuels (Morrow et al., 2010). In the absence of a clearly-differentiated strategy for different technologies in the portfolio, 
a simple benchmark test for portfolio alignment is a similar emphasis or equal weighting on directed efforts and targeted outcomes for any given technology (Table 1).

\section{Methodology}

\subsection{Indicators}

Innovation systems can be tracked and evaluated using indicators as descriptive proxy measures of key processes (IEA, 2011). To measure innovation system processes in the ETIS framework (Figure 1), we reviewed relevant literature to identify potential indicators (Borup et al., 2013; Klitkou et al., 2012; Grubler \& Wilson, 2014b; Cornell University et al., 2018; Truffer et al., 2012; Speirs et al., 2008; Park et al., 2016; Miremadi et al., 2016; Borup et al., 2008). We compiled a comprehensive set of $>100$ possible indicators, and then applied two selection criteria: usefulness and availability. Usefulness means indicators should capture specific innovation processes in the ETIS framework, be clearly understandable, and be generalisable across technology fields. Availability means indicators should be measurable from available data sources, drawing either on existing databases or on secondary data sets which allow technology-specific analysis.

The resulting set of indicators as general descriptors of ETIS processes are shown in the left columns of Table 3. Full details of how each indicator is constructed are provided in Appendix A. Collectively these indicators provide a comprehensive account of the ETIS framework represented in Figure 1. This set of indicators is generalisable to any energy innovation portfolio or technology, subject to data availability. While we cannot capture all of innovation system processes in the TIS, FIS, NIS literature, our indicators capture the main innovation system processes and so support systemic analysis. However, we acknowledge the difficulties caused by data availability and data collection. For example, some indicators in the literature are specific to one technology so cannot be generalised (e.g., capacity factors of power plants). Reliable cost data was also hard to find for all technologies in a standardised form. 


\subsection{The EU's SET Plan}

In this paper, we use the EU's SET Plan to demonstrate how the indicators can be used to analyse the design of energy innovation portfolios. The EU's Strategic Energy Technology (SET) Plan sets strategic priorities to support the European Commission's stated "ambition to achieve ... a fundamental transformation of Europe's energy system" (EC, 2015b). Aligned with the EU's longterm climate, energy security, renewable energy, and energy efficiency goals, the EU's SET Plan was launched in 2008 to provide strategic planning and coordination of energy research and innovation activities within the EU involving a diverse range of innovation actors (Carvalho, 2012). The SET Plan was implemented through European Industrial Initiatives for technologies with near-term market impact, demonstration and commercialisation programmes (e.g., NER 300), monitoring and evaluation (e.g., SETIS), and longer-term research actions (including Horizon 2020). The Strategic Energy Technologies Information System (SETIS) monitors progress and provides up-to-date information on the SET Plan (Corsatea et al., 2015). The SET Plan Steering Group is the central governance structure of the SET Plan, coordinating extensive stakeholder networks within each action (Joliff-Botrel, 2015). The SET Plan also articulates links to available EU funding mechanisms for energy research and innovation (EC, 2015b).

In 2015 the Commission proposed a revised SET Plan that was more targeted and used a whole systems approach to ensure better integration across sectors and technologies (EC, 2015b). As shown in Table 2, the revised SET Plan set out four priority areas (renewable energy, smart grid, energy efficiency, and sustainable transport) and two additional areas (carbon capture and storage, and nuclear power). These six areas were articulated in a set of ten actions. In this paper, we refer to the six priority and additional areas as 'technology fields' to denote groupings of inter-related technologies in a common field of application.

We choose the EU SET Plan because it is a major pan-national energy innovation portfolio which has been running for over a decade. Unlike other energy innovation portfolios which focus on $R \& D$ (such as ARPA-E in the US, or Mission Innovation globally), the SET Plan spans a wide range of 
innovation processes. Additionally, the SET Plan went through a major revision in 2015 with the specific aim of making it more integrated and systemic (EC, 2015b).

Table 2. Technology Portfolio of the EU's SET Plan. Source: (EC, 2015a). Note: In this paper, we use the term 'technology fields' to refer to the SET Plan's 'priority areas' and 'additional areas'.

\begin{tabular}{|c|c|c|}
\hline $\begin{array}{l}\text { SET } \\
\text { Plan }\end{array}$ & Technology Portfolio & Technology-Specific Actions \& Targets \\
\hline \multirow{8}{*}{$\begin{array}{l}\text { priority } \\
\text { areas }\end{array}$} & \multirow[t]{2}{*}{ Renewable Energy (RE) } & Performant renewable technologies integrated into the energy system \\
\hline & & Reduce costs of technologies \\
\hline & \multirow{2}{*}{ Smart Grid (SG) } & New smart techologies \& services for consumers \\
\hline & & Resilience, security \& smartness of energy system \\
\hline & \multirow[t]{2}{*}{ Energy Efficiency (EE) } & New materials \& technologies for buildings \\
\hline & & Energy efficiency for industry \\
\hline & \multirow{2}{*}{$\begin{array}{l}\text { Sustainable Transport } \\
\text { (ST) }\end{array}$} & Competitiveness in batteries \& e-mobility \\
\hline & & Renewable fuels \\
\hline \multirow{2}{*}{$\begin{array}{l}\text { additional } \\
\text { areas }\end{array}$} & $\begin{array}{l}\text { Carbon Capture and } \\
\text { Storage (CCS) }\end{array}$ & Application of carbon capture with storage or use \\
\hline & Nuclear Power (NP)* & High level of safety in nuclear reactors \& fuel cycles \\
\hline
\end{tabular}

* The SET Plan emphasises nuclear safety which we interpret broadly to include all nuclear fission-related research and innovation activity.

\subsection{Data for the EU SET Plan}

We collected data from diverse sources to measure each of our indicators for each of the six technology fields of the EU's SET Plan. The metrics, as well as the main data source and level of disaggregation (country-level aggregated up to the EU, or EU-level), are shown in the right columns of Table 3. Full details of the data used, database query codes, and other data search protocols are provided in Appendix B. We used data for 2015 as the most recent year for which most data were available. This cross-sectional approach is consistent with our aim of demonstrating how the design of energy innovation portfolios can be evaluated from a systemic perspective.

Following the approach used in Wilson et al. (2012), we collected technology-specific data for each indicator, distinguishing data measuring innovation system processes within the six SET Plan technology fields (e.g., related to renewable energy) from data measuring activity outside the SET Plan portfolio (e.g., liquified natural gas). For data related to the SET Plan, we calculated the relative proportion associated with each of the six technology fields. 


\subsection{Simple benchmark tests of portfolio design criteria}

As noted above, we propose simple benchmark tests for the three normative criteria of balance, consistency and alignment. Each test examines the relative shares of either technologies or innovation system processes in the portfolio, and uses an equally-weighted distribution or similar relative shares as the benchmark or reference point (Table 1). It is important to emphasise that these simple tests are not definitive assessments of portfolio design, but rather serve to draw portfolio managers' attention to areas of possible imbalance, inconsistency, or misalignment in their innovation portfolios. In other words our benchmark tests have a diagnostic rather than an evaluative function. As we discuss further below, there may be good reasons or arguments as to why portfolios perform poorly on these simple tests.

To evaluate balance in the EU's SET Plan, we use stacked bar charts to show the relative share of each indicator across the six technology fields. Balance would see an equally-weighted distribution or similar relative shares for the technology fields on each indicator measuring an innovation system process. This would mean a similar emphasis on each technology in the SET Plan portfolio.

To evaluate consistency, we use box-whisker plots to show the variability in the relative shares of all the indicators within each of the four ETIS dimensions for a given technology field. Consistency would see an equally-weighted distribution or similar relative shares for the innovation system processes, resulting in low variability. This would mean a similar emphasis on each innovation system process in the SET Plan portfolio.

To evaluate alignment, we follow the approach used to evaluate balance. However, in this case, we use stacked bar charts to show the average relative share of indicators in two groups of innovation system process - late stage and market outcomes - across the six technology fields. 'Alignment' would see an equally-weighted distribution or similar average relative shares for the technology fields in each group. This would mean a similar emphasis on late stage directed innovation efforts and targeted market outcomes in the SET Plan portfolio. The two outcomes we analyse are learning and market share. Learning measures cost reductions (or performance improvements) as a function of cumulative 
deployment experience including knowlege feedback from users. Market share measures the capacity of the new technology to displace incumbents' market dominance.

Table 3. Technology-specific indicators of innovation system processes.

\begin{tabular}{|c|c|c|c|c|}
\hline \multicolumn{2}{|c|}{ Generalisable indicators } & \multicolumn{3}{|c|}{ Application of indicators to the EU SET Plan } \\
\hline $\begin{array}{l}\text { Innovation } \\
\text { system processes } \\
\text { in the ETIS } \\
\text { framework }\end{array}$ & $\begin{array}{l}\text { Technology-specific indicators } \\
\text { of innovation system processes }\end{array}$ & $\begin{array}{l}\text { [Indicator metrics] for } \mathbf{E U} \\
\text { SET Plan }\end{array}$ & $\begin{array}{l}\text { Level of } \\
\text { data }\end{array}$ & $\begin{array}{l}\text { Main } \\
\text { data } \\
\text { source }\end{array}$ \\
\hline \multicolumn{5}{|l|}{ KNOWLEDGE } \\
\hline \multirow[t]{2}{*}{ Generation } & Public energy RD\&D expenditure & {$[€ \mathrm{~m}]$} & national & 1 \\
\hline & Demonstration budgets & {$[€ \mathrm{~m}]$} & national & 1 \\
\hline \multirow[t]{4}{*}{ Codification } & Publications & [\# articles] & national & 2 \\
\hline & $\begin{array}{l}\text { Citation-weighted publication } \\
\text { counts }\end{array}$ & [\# articles] & national & 2 \\
\hline & Patents & [\# patents] & national & 3 \\
\hline & Citation-weighted patent counts & [\# patents] & national & 3 \\
\hline \multirow[t]{2}{*}{$\begin{array}{l}\text { International } \\
\text { Flows }\end{array}$} & $\begin{array}{l}\text { Publication co-authorships (intra- } \\
\text { extra)* }\end{array}$ & $\begin{array}{l}\text { [index] of co-authorships } \\
\text { between EU and non-EU } \\
\text { actors }\end{array}$ & national & 2 \\
\hline & Patent co-inventions (intra-extra)* & $\begin{array}{l}\text { [index] of co-inventions } \\
\text { between EU and non-EU } \\
\text { actors }\end{array}$ & national & 3 \\
\hline Spillover & Energy technology imports & {$[€ \mathrm{~m}]$} & national & 4 \\
\hline Depreciation & $\begin{array}{l}\text { Volatility in energy RD\&D } \\
\text { expenditure }\end{array}$ & [coefficient of variation] & national & 1 \\
\hline \multicolumn{5}{|l|}{$\begin{array}{l}\text { RESOURCES \& } \\
\text { POLICIES } \\
\end{array}$} \\
\hline \multirow[t]{2}{*}{$\begin{array}{l}\text { Mobilisation of } \\
\text { Finances }\end{array}$} & $\begin{array}{l}\text { Public energy RD\&D expenditure } \\
\text { as } \% \text { of GDP }\end{array}$ & {$[\%]$} & national & 1 \\
\hline & Top 100 clean-tech funds & {$[€ \mathrm{~m}]$} & EU & 8 \\
\hline $\begin{array}{l}\text { Mobilisation of } \\
\text { Innovators }\end{array}$ & $\begin{array}{l}\text { Patent activity as \% of total } \\
\text { patents }\end{array}$ & {$[\%]$} & national & 3 \\
\hline Policy Density & $\begin{array}{l}\text { Policy density (innovation) } \\
\text { Policy density (regulatory) } \\
\text { Policy density (market-based) }\end{array}$ & $\begin{array}{l}\text { [\# instruments] of } \\
\text { innovation, regulatory and } \\
\text { market-based policies }\end{array}$ & national & 6 \\
\hline Policy Durability & $\begin{array}{l}\text { Policy durability (innovation) } \\
\text { Policy durability (regulatory) } \\
\text { Policy durability (market-based) }\end{array}$ & $\begin{array}{l}\text { [average of cumulative \# } \\
\text { instruments] of innovation, } \\
\text { regulatory and market-based } \\
\text { policies }\end{array}$ & national & 6 \\
\hline Policy Mix & Diversity of policy instruments & [Shannon index] & national & 6 \\
\hline Policy Stability & Stability of policy instruments & $\begin{array}{l}\text { [average of cumulative years } \\
\text { of all instruments, adjusted } \\
\text { by revisions] }\end{array}$ & national & 6 \\
\hline $\begin{array}{l}\text { Regulatory } \\
\text { Capture }\end{array}$ & $\begin{array}{l}\text { Public RD\&D expenditure on } \\
\text { fossil fuels }\end{array}$ & {$[€ \mathrm{~m}]$} & national & 1 \\
\hline \multicolumn{5}{|l|}{$\begin{array}{l}\text { ACTORS \& } \\
\text { NETWORKS }\end{array}$} \\
\hline Heterogeneity & $\begin{array}{l}\text { Diversity of types of organisation } \\
\text { in publication activity }\end{array}$ & [index] & national & 2 \\
\hline
\end{tabular}




\begin{tabular}{|c|c|c|c|c|}
\hline & $\begin{array}{l}\text { Diversity of types of organisation } \\
\text { in patenting activity }\end{array}$ & [index] & national & 3 \\
\hline & $\begin{array}{l}\text { Diversity of types of organisation } \\
\text { in research collaborations }\end{array}$ & $\begin{array}{l}\text { [Shannon index] for } \\
\text { European Energy Research } \\
\text { Alliance }\end{array}$ & $\begin{array}{l}\text { national } \\
\& \text { EU }\end{array}$ & 9 \\
\hline \multirow[t]{3}{*}{$\begin{array}{l}\text { Exchange \& } \\
\text { Interaction }\end{array}$} & $\begin{array}{l}\text { Publication co-authorships (intra- } \\
\text { intra)* }\end{array}$ & $\begin{array}{l}\text { [index] of co-authorships } \\
\text { between different EU actors }\end{array}$ & national & 2 \\
\hline & Patent co-inventions (intra-intra)* & $\begin{array}{l}\text { [index] of co-inventions } \\
\text { between different EU actors }\end{array}$ & national & 3 \\
\hline & $\begin{array}{l}\text { Research collaborations (intra- } \\
\text { intra)* }\end{array}$ & $\begin{array}{l}\text { [\# of activities] involving } \\
\text { different EU actors in } \\
\text { European Energy Research } \\
\text { Alliance }\end{array}$ & $\begin{array}{l}\text { national } \\
\& \text { EU }\end{array}$ & 9 \\
\hline \multirow[t]{2}{*}{$\begin{array}{l}\text { Shared } \\
\text { Expectations }\end{array}$} & Policy target density & $\begin{array}{l}\text { [\# instruments] of targets, } \\
\text { roadmaps, action plans }\end{array}$ & national & 6 \\
\hline & Policy target durability & $\begin{array}{l}\text { [average of cumulative \# } \\
\text { instruments] of targets, } \\
\text { roadmaps, action plans }\end{array}$ & national & 6 \\
\hline Legacy of Failure & $\begin{array}{l}\text { Decline in interest following a } \\
\text { failure }\end{array}$ & $\begin{array}{l}\text { [exponent of decline } \\
\text { function fitted to Google } \\
\text { search frequency] }\end{array}$ & global & 7 \\
\hline \multicolumn{5}{|l|}{$\begin{array}{l}\text { USERS \& } \\
\text { MARKETS }\end{array}$} \\
\hline Learning & Learning-by-doing & $\begin{array}{l}\text { [learning rate, } \% \text { cost } \\
\text { reduction per doubling of } \\
\text { cumulative experience] }\end{array}$ & global & 5 \\
\hline $\begin{array}{l}\text { Potential Market } \\
\text { Size }\end{array}$ & Potential market size & $\begin{array}{l}{[€ \mathrm{~m}] \text { estimated as total } \# \text { of }} \\
\text { physical units } * € \text { cost per } \\
\text { unit }\end{array}$ & national & 5 \\
\hline Market Share & Market share & $\begin{array}{l}{[\%] \text { estimated as actual }} \\
\text { market size / potential } \\
\text { market size }\end{array}$ & national & 5 \\
\hline
\end{tabular}

Table notes:

* Intra and extra refer to patents filed or publications authored from within the innovation region being analysed (intra) or from other regions (extra), hence international knowledge flows include both intra and extra, whereas exchange and interaction include only intra.

Main data sources (see Appendices A \& B for full details):

1 International Energy Agency (IEA) energy RD\&D statistics

[http://wds.iea.org/WDS/Common/Login/login.aspx];

$2 \mathrm{Web}$ of Science [https://login.webofknowledge.com/];

3 United States Patent and Trademark Office (USPTO) PatentsViews database

[http://www.patentsview.org/web/];

4 Eurostat EU trade statistics [http://ec.europa.eu/eurostat/web/international-trade-in-goods/data/database];

5 Secondary data from peer-reviewed studies;

6 IEA Addressing Climate Change policy database [https://www.iea.org/policiesandmeasures/climatechange/];

7 Google Trends [https://trends.google.com/trends/?geo=];

8 Global Cleantech 100 [https://www.cleantech.com/];

9 European Energy Research Alliance (EERA) [https://www.eera-set.eu/].

\section{Findings}

\subsection{Balance across six technology fields in the EU's SET Plan portfolio}

Figure 3 shows whether the relative emphasis on each of the six technology fields in the SET Plan portfolio is balanced across the full set of innovation system processes, grouped by the four 
dimensions of the ETIS framework shown in Figure 1. Similar relative shares indicate balance in our simple benchmark test. Clear examples in Figure 3 include knowledge generation by public energy RD\&D expenditure and knowledge depreciation measured by volatility in RD\&D expenditure. Policy support (density and durability) and policy mix (diversity and stability) are also fairly evenly distributed between the four priority areas of the SET Plan (i.e., excluding nuclear power and CCS). This is an interesting indication of policymaking employing a diverse mix of instruments in all technology fields. These are broadly expected results as policy instruments and RD\&D expenditure are directly manageable by policymakers. Innovation system processes measuring actors and networks active within the EU energy innovation system are also mostly balanced across the six technology fields. A core feature of the SET Plan is its bringing together of stakeholders to plan and cooperate around strategic research objectives and technology roadmaps.

Markedly different relative shares indicate imbalance. Clear examples in Figure 3 include knowledge generation measured by demonstration budgets for which sustainable transport accounts for $50 \%$ of total activity and renewable energy a further $27 \%$. This is attributable to a recent increase in funding for demonstration activity in the sustainable transport area (Zubaryeva et al., 2015). Knowledge codification measured by patents is also imbalanced, with a high relative share of energy efficiency patent applications. This is likely due to the stable market environment regulated by efficiency standards and backed by long-term targets which incentivise innovators to capture the large remaining potential for efficiency gains (Cullen \& Allwood, 2010). Knowledge codification measured by publications is also imbalanced, but in this case skewed towards renewable energy. One interpretation is that the integration of renewable energy into power systems poses challenges for a wide range of research communities from engineering and material science to economics and planning, with this diversity stimulating publication activity. These too are not unsurprising results as patents and publications are not directly manageable by policymakers.

Intra-extra EU collaboration on patents and publications as a measure of international knowledge flows are also strongly imbalanced with sustainable transport accounting for about $60 \%$ of the total. One interpretation is that the global automotive industry's concentrated market structure, dominated 
by Japan and the United States, provides strong incentives for EU innovators to cooperate with nonEU actors. Knowledge spillovers measured by the value of energy technology imports into the EU are also strongly imbalanced with renewable energy accounting for about $30 \%$ of the total. This finding is in line with a recent study showing that EU has a negative trade balance in solar photovoltaics (Pasimeni, 2017).

The users \& markets dimension of the ETIS framework is characterised by only three indicators in Figure 3. However, each shows a distinctive imbalance. Learning-by-doing is dominated by energy efficiency, which is broadly expected as it is the most mature and sustained of the SET Plan technology fields with more substantial cumulative experience. Potential market size is dominated by sustainable transport as the vehicle market in $€$ terms is large, with some modelling studies already showing the potential for fully electrifying the vehicle fleet in the medium-to-long term (Connolly et al., 2016). Actual market share is fairly evenly distributed across four technology fields, with sustainable transport and CCS notable by their lack of deployment track record to-date. Despite their market maturity, the current market shares of energy efficiency, renewable energy and nuclear power remain supported by late stage innovation system processes including regulatory and market-based policy instruments.

These areas of imbalance shown clearly in Figure 3 do not inherently cause for concern. They may have good reason and be defensible. Portfolio managers may also be limited in their capacity to redress the imbalance. The purpose of our benchmark test applied here is to identify areas of imbalance which potentially require further attention should they compromise the risk-diversification characteristics of the SET Plan technology portfolio.

In sum, our analysis of balance defined as similar weighting across the six technology fields in the EU SET Plan portfolio shows:

- balance in RD\&D expenditures and public policy

- imbalance in knowledge codification, flows and spillover (towards renewable energy, energy efficiency, or sustainable transport depending on the innovation system process) 
- more balance for innovation system processes for which policymakers have more direct control or management capacity

- less balance in innovation system processes for which policymakers have less direct control and which are subject to more intervening factors or conditions (e.g., market structure, stability of innovation environment) 

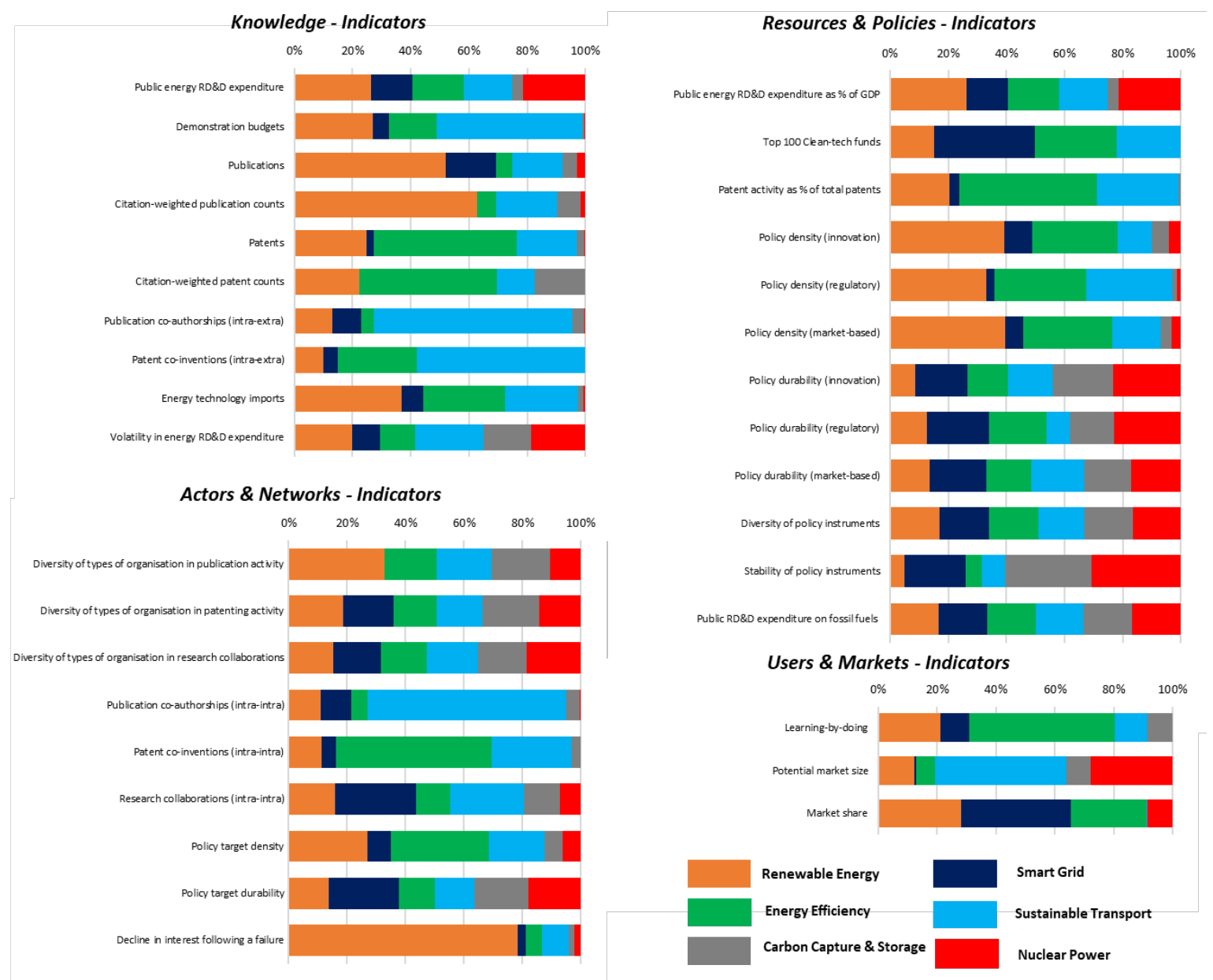

Figure 3. Relative shares of six technology fields for each innovation system process in the EU SET Plan using 2015 data. 


\subsection{Consistency across innovation system processes in the EU'S SET Plan portfolio}

Figure 4 shows whether the relative emphasis on innovation system processes within each of the four ETIS dimensions is consistent for the six technology fields in the SET Plan portfolio. Low variability in relative shares indicates consistency based on our simple benchmark test. As shown in Figure 4, innovation system processes relating to resources \& policies and to actors \& networks are noticeably more consistent (lower variability) than those relating to knowledge (Innovation system processes relating to users $\&$ markets are not shown due to the small number of indicators).

Inconsistency between knowledge-related innovation system processes is clearest for renewable energy, energy efficiency and sustainable transport. In these technology fields, some knowledgerelated processes have dominant shares in the SET Plan portfolio, whereas others have only weak shares. This can be further examined by comparing the specific processes which provide the upper and low bound in each case.

Inconsistency between knowledge-related innovation system processes for renewable energy ranges from citation-weighted publication counts (upper bound, 63\% relative share) to patent coinventions between EU and non-EU actors (lower bound, 10\% relative share). This patent coinventions indicator is a measure of international knowlege flows. One explanation why it may have a low relative share in the SET Plan portfolio is that the EU is a firstmover particularly with respect to renewables deployment. Moreover innovation activity for renewable energy may be concentrated in regions with available resource or with energy security concerns. Indirect evidence for this explanation is provided by the high volume of single authors and single inventors in renewable energy compared to the other technology fields.

Inconsistency between knowledge-related innovation system processes for energy efficiency ranges from patents (upper bound, 49\% relative share) to publication co-authorship between EU and non-EU actors (lower bound, $4 \%$ relative share). As noted earlier, this high relative share of patenting activity is consistent with clear expectations for returns on innovation investments in energy efficiency due to stable regulatory policy environments including the EU's Energy Efficiency Directive and large market potentials still available. Conversely, the low relative share of international 
knowledge flows measured by publication co-authorships may be explained by the EU's strong internal competence in this field.

Inconsistency between knowledge-related innovation system processes for sustainable transport ranges from publication co-authorship between EU and non-EU actors (upper bound, $68 \%$ relative share) to citation-weighted patent counts (lower bound, $13 \%$ relative share). As noted earlier, this high relative share of international knowledge flows may be linked to the EU's need to link with innovation centres on vehicle manufacturing in the US, Japan and elsewhere. The low relative share of citation-weighted patents may reflect the relative immaturity of the electric vehicle field compared to renewables and energy efficiency in which successful patents with higher citations are more established.

A more general explanation for inconsistency within any given ETIS dimension is that it's the result of early stage and late stage innovation system processes being combined. We use 'late stage' to mean directly related to or associated with the materialisation of technology in a market context: e.g., investment in an operational facility. Materialisation is a key late-stage function of innovation systems (Hekkert et al., 2007). Conversely, we use 'early stage' to mean directly related to or associated with pre-commercial or niche technology development: e.g., patents or publications describing new applications of knowledge. Early stage processes are more closely associated with technology development and testing, and technology-push policies such as RD\&D incentives. Late stage innovation system processes are more closely associated with market formation and deployment, and market-pull policies such as purchase subsidies.

This is a crude but useful distinction as more mature technologies can capture returns to scale and so benefit from cost reductions (from learning and scale economies) and regulatory alignment. This positive feedback loop creates path dependence as technologies which initially outcompete rivals become entrenched over time.

To test this explanation, we distingish all innovation system processes as being either early stage or late stage. We treat all $\mathrm{RD} \& \mathrm{D}$, patent, publication and innovation policy-related processes as early stage. Conversely, we characterise all market-based policy, regulatory policy, learning, market size, 
and trade-related processes as late stage. We characterise research collaborations and strategic policies (e.g., targets, roadmaps) as both early and late stage as they span the full innovation lifecycle. We then reanalyse inconsistency for early and late stage innovation system processes separately. However, we find that this does not explain inconsistency in any of the ETIS dimensions, so we reject this explanation (see Appendix $\mathrm{C}$ for full details). However, it should be noted that as we characterised most knowledge-related processes as early stage, this is unlikely to help explain the main inconsistencies observed in Figure 4.

In sum, our analysis of consistency defined as similar weighting across innovation system processes in the EU SET Plan portfolio shows:

- consistency (similar relative emphasis) for innovation system processes relating to resources \& policies and actors \& networks across all techology fields

- inconsistency (varying relative emphasis) for innovation system processes relating to knowledge for renewable energy, energy efficiency, and sustainable transport

- inconsistency is not explained by differing emphases on early and late stage innovation system processes 
Variation in 10 knowledge-related indicators

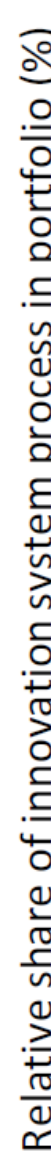

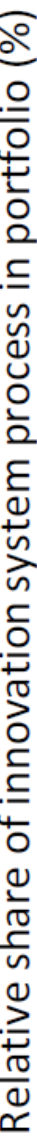

$100 \%$

$80 \%$

$60 \%$

$40 \%$

$20 \%$

$0 \%$

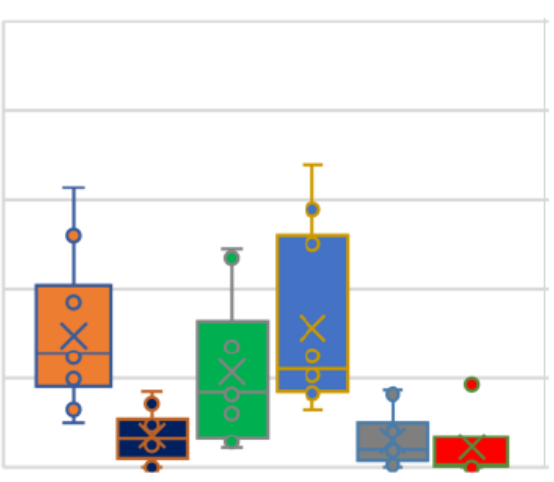

Variation in 9 actors \& networks-

\section{related indicators}

$100 \%$

$80 \%$

ㄴ.

$\begin{array}{ll}\frac{1}{\pi} & 60 \% \\ \frac{2}{n} & 40 \%\end{array}$

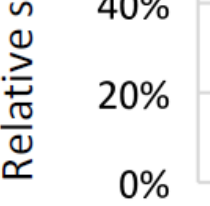

Variation in 12 resources \&

policies-related indicators
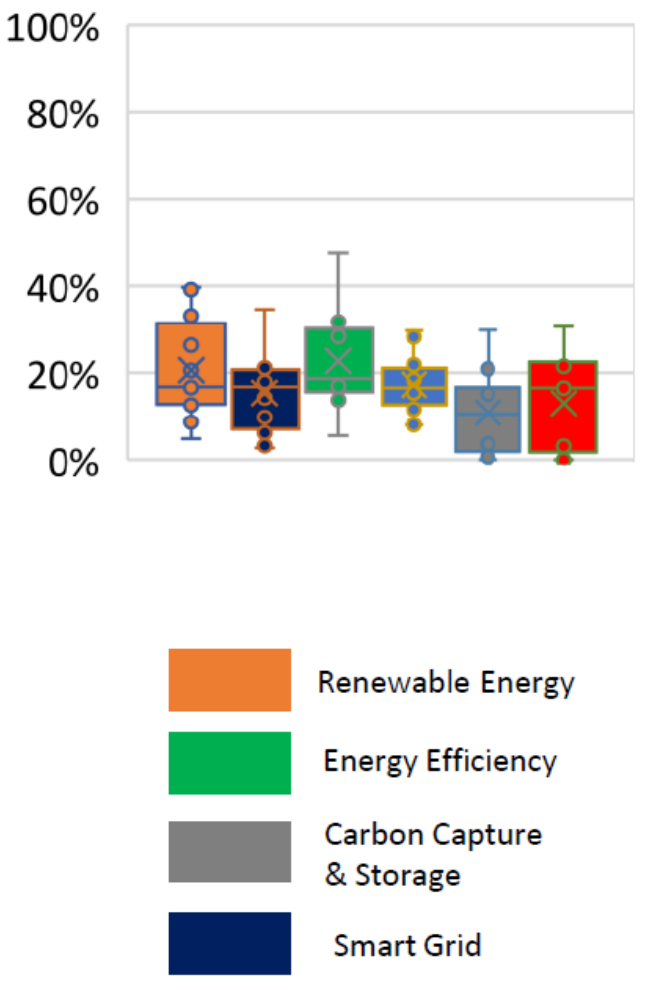

Renewable Energy

Energy Efficiency

Carbon Capture

\& Storage

Smart Grid

Sustainable

Transport

Nuclear Power

Figure 4. Relative shares of innovation system processes in each ETIS dimension for the six technology fields in the EU SET Plan using 2015 data. Note: o indicate data points with X as mean, median; box shows second \& third quartiles separated by line; whiskers show first \& fourth quartiles. 


\subsection{Alignment between late-stage innovation system processes and market outcomes in the EU's}

SET Plan portfolio

Figure 5 shows whether the relative emphases on six technology fields averaged across late stage innovation system processes in three dimensions of the ETIS framework are aligned with learning and market share as desirable innovation outcomes. Similar relative shares across late stage and outcome indicators indicate alignment, based on our simple benchmark test. As shown in Figure 5, the weighting of emphasis across the EU's SET Plan technology portfolio is evenly distributed for late stage innovation system processes, although knowledge-related processs (energy technology imports) have negligible shares for CCS and nuclear power. Figure 5 also shows that the relative shares are fairly well aligned between late stage innovation system processes and market outcomes, with two exceptions.

First, learning is skewed towards energy efficiency which, as we noted earlier, is likely associated with the mature and durable policy environment for energy efficiency improvements coupled with the large and relatively low-cost market opportunities remaining for deployment. Second, market share is low or missing for sustainable transport and CCS, but for different reasons. Market incentives for CCS are too weak to support deployment, whereas full or partially electric vehicles are deploying slowly at the margins due to their high relative cost, consumer resistance to different service attributes (such as range), and other socio-technical barriers (such as recharging availability).

The high relative share of energy efficiency on the learning indicator points to the need for more supportive learning conditions in other parts of the SET Plan portfolio, particularly smart grids. The regulated smart meter rollout is effective in driving market share but may not create dynamic incentives for technology improvement. CCS and nuclear power have low relative shares, but learning is more problematic due to their large unit sizes and costs, high barriers to entry, bespoke designs and construction, all of which undermine the repetitive experience necessary for learning-by-doing.

The low relative shares of sustainable transport and CCS on the market share indicator point to an inherent limitation of comparing relative shares in a technology portfolio rather than absolute measures of market uptake (MW, $€, € / M W)$. A given absolute amount of deployment may be high in 
some fields but low in others. Low relative shares may be due not just to weak innovation system functioning but also to strong performance elsewhere in the portfolio. In the case of CCS, the negligible market share is despite a high potential market size and a mature technology field with applications in enhanced oil recovery dating back decades. The lack of adequate deployment incentives for CCS points to another limitation with policy-related indicators which don't take into account stringency, as the presence or absence of supportive policy is distinct from the extent of support. However, it's also notable that knowledge-related innovation system processes for CCS have generally quite low relative shares in the EU's SET Plan portfolio (Figure 3) pointing to a more systemic weakness in directed innovation efforts to support CCS development.

In sum, our analysis of alignment across innovation system processes for each of the six technology fields in the EU SET Plan portfolio shows:

- broad alignment (similar relative emphasis) between late stage innovation system processes and learning across all techology fields, with the exception of a high relative share of energy efficiency on learning

- broad alignment (similar relative emphasis) between late stage innovation system processes and market share across all technology fields, with the exception of low relative shares of sustainable transport and CCS on market share

- misalignment is explained by differences in the adoption environments between technology fields: mature and stable for energy efficiency; emerging and very large in size for sustainable transport; concentrated and weakly incentivised for CCS

- misalignment also points to the weaker relevance of innovation system processes for mature technologies deploying in market environments 


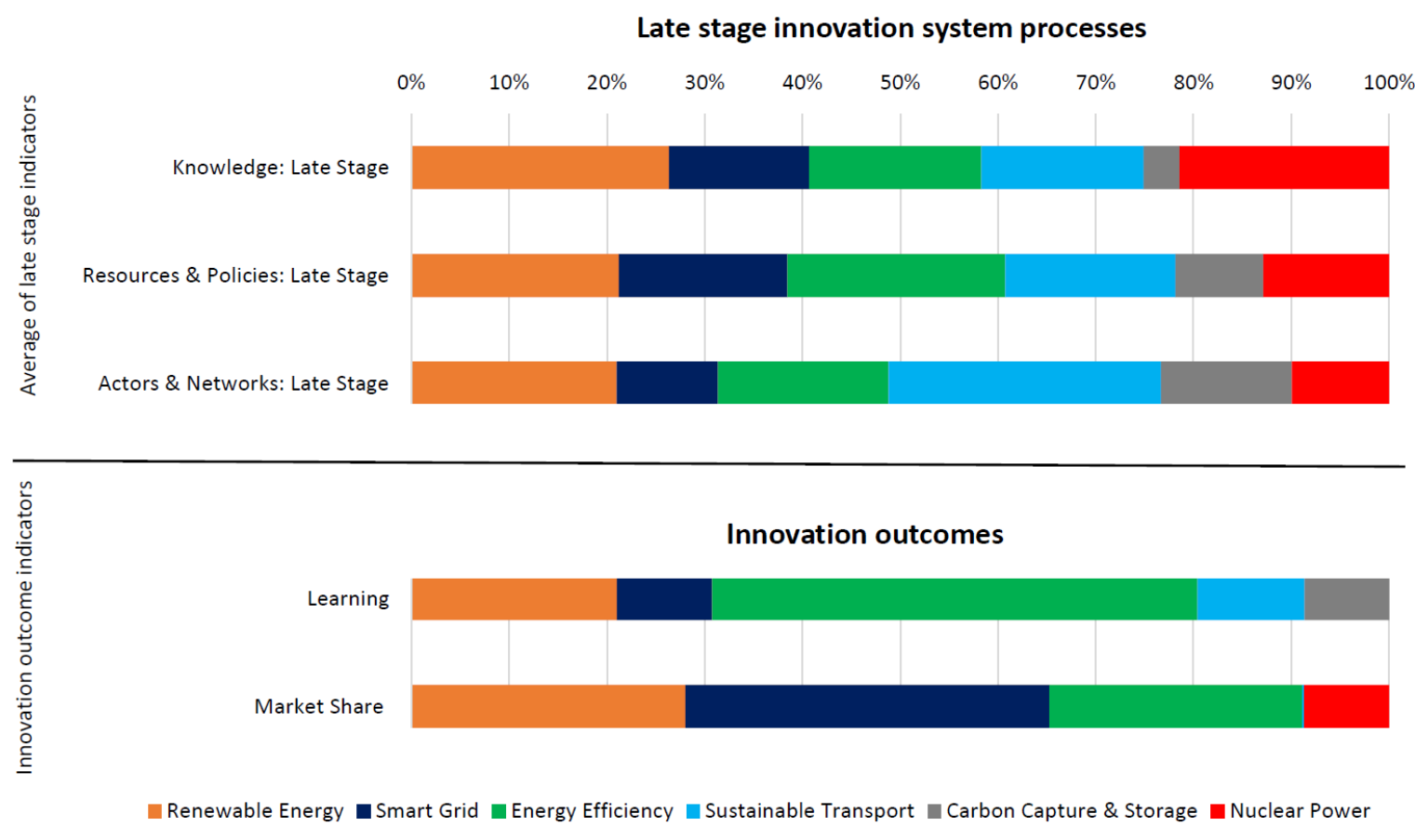

Figure 5. Relative share of six technology fields between indicators of late stage innovation system processes and two outcomes indicators relating to users \& markets.

\section{Conclusions and Policy Implications}

Balance, consistency and alignment are all normative criteria for the design of innovation portfolios comprising both multiple technologies and a range of policy interventions through which portfolio managers can exert direct, indirect, or systemic influence over diverse innovation system processes (Figure 2). All three criteria have a robust basis in the literature and a strong rationale: balance between technologies to diversify risk (Grubler \& Riahi, 2010); consistency between innovation system processes to coordinate inter-dependent activity throughout the innovation system (Bergek et al., 2008; Grubler \& Wilson, 2014a); alignment between directed innovation efforts and outcomes to ensure innovation systems are oriented towards desired goals (Wilson et al., 2012).

How these criteria should be analysed for any given energy innovation portfolio is less definitive. Portfolio managers may provide transparent rationales for intended portfolio composition, setting ex ante conditions for the relative emphasis placed on certain technologies or innovation system 
processes. Independent analysis may recommend optimal portfolio designs using a range of tools to support decision-making under uncertainty (Anadon et al., 2017).

In our analysis of the EU's SET Plan porfolio, we apply simple benchmark tests of 'similar relative shares' to provide an initial indication of where the portfolio may be imbalanced, inconsistent, or misaligned (Table 1). We emphasise again that these simple tests using relative equal shares as the benchmark serve an initial diagnostic function and should not be overinterpreted. As an example, learning rates would be expected to vary across technologies with different characteristics and maturities, and so non-equal relative shares on this one indicator would not inherently mean an energy innovation portfolio was imbalanced and, by implication, poorly designed. Rather the benchmark test would raise non-equal relative shares as a diagnostic flag warranting further attention. Portfolio managers would therefore seek explicit and clearly justifiable reasons for why learning rates varied strongly across the portfolio. More broadly, our benchmark test for consistency applies across the full spectrum of innovation processes. So in the case of learning rates, the benchmark test would also identify portfolios in which a technology was performing relatively well in terms of learning-related cost reductions, but relatively poorly in terms of other conditions necessary for sustained deployment. This again would raise the area as one warranting further attention by portfolio managers.

In the previous sections, we offered an explanation or interpretation of most such cases in which the benchmark tests point to areas of potential imbalance, inconsistency, or misalignment. Here we focus on those cases which do not have immediately apparent justifications as being areas warranting attention by SET Plan portfolio managers.

Applying our simple benchmark test for balance, we found evidence that the SET Plan portfolio is broadly balanced in its technological emphasis for innovation system processes over which it has direct managerial competence (e.g., public energy RD\&D investments). Areas of potential imbalance include knowledge codification, flows and spillovers over which portfolio managers have only indirect influence. In 2015, these were variously skewed towards renewable energy, energy efficiency or sustainable transport. Portfolio managers could use a range of approaches for redressing imbalance in these areas including: introducing tied conditions to research funding (e.g., on requirements for 
scientific publication); strengthening basic research with higher propensity to generate influential intellectual property (e.g., through ERC programmes); targeting research funding to support single actor research projects with fewer constraints on intellectual property protection (e.g., through Horizon 2020 programmes); or support for public-private research consortia with higher propensity to engage in open knowlege exchange (e.g., through informal stakeholder networks and formal research frameworks such as the European Industrial Initiatives).

Applying our simple benchmark test for consistency, we found evidence that the SET Plan portfolio is broadly consistent in terms of innovation system processes working in concert in each of the six technology fields, spanning both early state and late stage processes. Areas of potential inconsistency include a skewed emphasis among knowledge-related innovation system processes towards influential (citation-weighted) patents in renewable energy, towards patents in energy efficiency, and towards publication co-authorships in sustainable transport. In each case, portfolio managers can not directly boost activity in under-performing processes to improve consistency. However, there a range of approaches available for stimulating knowledge codification, flows and spillovers including those suggested above in relation to imbalance, as well as stronger incentives for active stakeholder participation in roadmap development.

Applying our simple benchmark test for alignment, we found evidence that late stage innovation processes in the SET Plan portfolio are broadly aligned with learning and market share as targeted innovation outcomes. Areas of potential misalignment include a weak relative emphasis on learning for smart grids and nuclear power, and a weak relative emphasis on market share for sustainable transport and CCS. Nuclear and CCS are exceptional in being large, complex, centralised technologies with relatively closed innovation systems in terms of numbers of actors, actor heterogeneity, and incumbency. EU-level coordination and direction of innovation in these technology fields matches these scale characteristics, but high costs, low funding for demonstration, low and uncertain price support combine to provide inadequate market deployment incentives for innovators ( $\AA$ hman et al., 2018). Low market share for sustainable transport is the result of relatively slow change at the margins (new vehicle sales) being absorbed into a large stock (all vehicles), 
reinforcing the importance of strong market-pull incentives in the form of purchase subsidies, differential tax regimes (e.g., feebates to discourage fossil-fuelled vehicles and encourage nonpolluting alternatives), and charging or alternative-fuel vehicle charging or refuelling infrastructures (McCollum et al., 2018). Low learning for smart grids is the likely result of regulated smart meter rollout programmes failing to provide dynamic incentives for technology improvement. As with imbalance and inconsistency, these areas of potential misalignment invite redress by SET Plan portfolio managers.

This paper provides a systemic perspective on innovation portfolios using a diverse set of newlyconstructed indicators which are applicable to specific energy technologies. Our approach provides a valuable analytical perspective on the design of effective policy environments to stimulate innovation activity that is critical for meeting ambitious energy system transformation goals. This paper is a first effort to bring a wide range of innovation system processes into the realm of comparative, quantitative analysis using a standardised and generalisable set of indicators.

We applied these indicators to analyse three design criteria for innovation portfolios: balance, consistency, alignment. We propose simple benchmark tests for each of these criteria, recognising that in specific cases, portfolio managers have defined robust and transparent conditions for technological diversity (balance), directed innovation efforts (consistency), and targeted outcomes (alignment). Using data for 2015 on the six technology fields in the EU's SET Plan, we show how our approach, criteria and tests can help identify potential areas of concern within the design of current innovation portfolios, inviting further attention from portfolio managers.

Our main findings on the EU's SET Plan portfolio are:

- the SET Plan portfolio is broadly balanced across technologies in terms of RD\&D expenditures and public policy instruments, but shows imbalance in knowledge codification, flows and spillover over which portfolio managers do not have direct control

- the SET Plan portfolio is broadly consistent across innovation system processes relating to policies and actors, but shows inconsistency in knowledge-related processes which can not be explained by differences between emerging and more mature technologies 
- the SET Plan portfolio is broadly aligned between late stage innovation system processes and market outcomes, but shows imbalance in learning and market share in particular technology fields

In this paper we have applied our benchmark tests for balance, consistency and alignment using historical data for a standardised set of technology-specific indicators. These same indicators could potentially be used to track progress over time in the design of innovation portfolios, just as the annual Global Innovation Index reports track progress in national innovation systems (Cornell University et al., 2018). The general diagnostic nature of the benchmark tests, coupled with uncertainties and contingencies in the energy innovation system, mean indicators for tracking progress should not be overinterpreted (see above). However, a portfolio which was becoming less and less balanced, consistent or aligned over time should raise the attention of portfolio managers to examine reasons why.

We also recognise important limitations with our approach which warrant further research and development. First, research on energy technology innovation indicators provides useful insights on availability and appropriate use (Borup et al., 2013; Klitkou et al., 2012; Hu et al., 2017; Hu et al., 2018), but does not systematically and apply a comprehensive set of indicators to compare across technologies. We propose our indicator framework as being generalisable across countries and technology fields (Table 3) but only demonstrate it for six technology fields in an EU context. Its applicability in other contexts needs further data collection efforts and testing.

Second, we demonstrated the applicability of our indicators using only a static cross-sectional perspective. Dynamic time-series analysis of the indicators is necessary for teasing out cause and effect relationships between innovation system processes including targeted outcomes (e.g., successful diffusion). Further research is needed to test time-dependent empirical relationships between innovation system processes. We have applied our benchmark tests for balance, consistency and alignment using historical data for a standardised set of technology-specific indicators. These same indicators could potentially be used to track progress over time in the design of innovation portfolios, just as the annual Global Innovation Index reports track progress in national innovation 
systems (Cornell University et al., 2018). The general diagnostic nature of the benchmark tests, coupled with uncertainties and contingencies in the energy innovation system, mean indicators for tracking progress should not be overinterpreted. However, a portfolio which was becoming less and less balanced, consistent or aligned over time over time should raise the attention of portfolio managers to examine reasons why.

Third, we used data describing technology-specific innovation system processes at the EU level. These take place within the context of economy-wide conditions (e.g., education, training, trade) which also need to be taken into account. Similarly, data describing member state-level innovation activity within the EU may reveal balance or imbalance at the national level, and the extent to which there is specialisation or harmonisation between the member states in terms of their contribution to SET Plan objectives. 


\section{Acknowledgements}

YJK and CW were supported by funding from the European Union's Horizon 2020 research and innovation programme under grant agreement No. 691843 (SET-Nav). CW was additionally supported by ERC Starting Grant No. 678799 (SILCI). The authors are very grateful for constructive comments and suggestions at a foundational stage of this work from Anna Wieczorek, Fionn Rogan, Matt Hannon, and Laura Diaz Anadon. An earlier version of the paper was presented at the IAEE European Conference 2017 in Vienna. We thank the anonymous reviewers for their careful reading of our manuscript and their many insightful comments and suggestions. 


\section{References}

Åhman, M., Skjaerseth, J. B., \& Eikeland, P. O. (2018). Demonstrating climate mitigation technologies: An early assessment of the NER 300 programme. Energy Policy, 117(July 2017), 100-107. https://doi.org/10.1016/j.enpol.2018.02.032

Anadon, L. D., Baker, E., \& Bosetti, V. (2017). Integrating uncertainty into public energy research and development decisions. Nature Energy, 2(5), 17071. https://doi.org/10.1038/nenergy.2017.71

Balconi, M., Brusoni, S., \& Orsenigo, L. (2010). In defence of the linear model: An essay. Research Policy, 39(1), 1-13. https://doi.org/10.1016/J.RESPOL.2009.09.013

Bergek, A., Jacobsson, S., Carlsson, B., Lindmark, S., \& Rickne, A. (2008). Analyzing the functional dynamics of technological innovation systems: A scheme of analysis. Research Policy, 37(3), 407-429. https://doi.org/10.1016/j.respol.2007.12.003

Borup, M., Andersen, D., Jacobsson, S., \& Midttun, A. (2008). Nordic energy innovation systems Patterns of need integration and cooperation. Innovation, (November), 129. Retrieved from http://www.nordicenergy.org/wp-content/uploads/2012/02/Nordic-energy-innovation-systemsPatterns-of-need-integration-and-cooperation.pdf

Borup, M., Klitkou, A., Andersen, M. M., Hain, D. S., Lindgaard, J., \& Rennings, K. (2013). Indicators of energy innovation systems and their dynamics: A review of current practice and research in the field.

Carlsson, B, \& Stankiewicz, R. (1991). On the nature, function and composition of technological systems. Journal of Evolutionary Economics, 1(2), 93-118. https://doi.org/10.1007/BF01224915

Carlsson, Bo, \& Jacobsson, S. (1994). Technological systems and economic policy: the diffusion of factory automation in Sweden. Research Policy, 23(3), 235-248. https://doi.org/https://doi.org/10.1016/0048-7333(94)90036-1

Carvalho, M. da G. (2012). EU energy and climate change strategy. Energy, 40(1), 19-22. https://doi.org/10.1016/j.energy.2012.01.012

Connolly, D., Lund, H., \& Mathiesen, B. V. (2016). Smart Energy Europe: The technical and economic impact of one potential 100\% renewable energy scenario for the European Union. Renewable and Sustainable Energy Reviews, 60, 1634-1653. https://doi.org/10.1016/J.RSER.2016.02.025

Cornell University, INSEAD, \& WIPO. (2018). The Global Innovation Index 2018: Energizing the World with Innovation. Ithaca, Fontainebleau, and Geneva.

Corsatea, T., Fiorini, A., Georgakaki, A., \& Lepsa, B. (2015). Capacity Mapping: $R$ \& D investment in SET-Plan technologies Reference year 2011. JRC Science and Policy Reports. https://doi.org/10.2790/751673

Cullen, J. M., \& Allwood, J. M. (2010). The efficient use of energy: Tracing the global flow of energy 
from fuel to service. Energy Policy, 38(1), 75-81. https://doi.org/10.1016/J.ENPOL.2009.08.054

EC. (2007). COM 723 (final). A European Strategic Energy Technology Plan (SET Plan): “Towards a low carbon future." Brussels, Belgium.

EC. (2015a). SET Plan actions: Implementation process and expected outcomes.

EC. (2015b). Towards an Integrated Strategic Energy Technology (SET) Plan: Accelerating the European Energy System Transformation. Brussels, Belgium.

Freeman, C. (1987). Technology, policy, and economic performance: lessons from Japan. Pinter Publishers.

Freeman, Chris. (1995). The National System of Innovation in historical perspective. Cambridge Journal of Economics, 19(1993), 5-24. https://doi.org/Article

Fuss, S., \& Szolgayová, J. (2010). Fuel price and technological uncertainty in a real options model for electricity planning. Applied Energy, 87(9), 2938-2944. https://doi.org/https://doi.org/10.1016/j.apenergy.2009.05.020

Gallagher, K., Grubler, A., Kuhl, L., Nemet, G., \& Wilson, C. (2012). The Energy Technology Innovation System. Annual Review of Environment and Resources, 37, 137-162. https://doi.org/10.1146/annurev-environ-060311-133915

Grubb, M., McDowall, W., \& Drummond, P. (2017). On order and complexity in innovations systems: Conceptual frameworks for policy mixes in sustainability transitions. Energy Research \& Social Science, 33, 21-34. https://doi.org/10.1016/J.ERSS.2017.09.016

Grubler, A., Aguayo, F., Gallagher, K., Hekkert, M., Jiang, K., Mytelka, L., ... Wilson, C. (2012). Global Energy Assessment - toward a sustainable future: Chapter 24: Policies for the Energy Technology Innovation System (ETIS). In L. G.-E. Thomas B. Johansson, Anand Prabhakar Patwardhan, Nebojša Nakićenović (Ed.), Global Energy Assessment - Toward a Sustainable Future (pp. 1665-1743). Cambridge University Press.

Grubler, A., \& Riahi, K. (2010). Do governments have the right mix in their energy R\&D portfolios? Carbon Management, 1(1), 79-87. https://doi.org/10.4155/cmt.10.16

Grubler, A., \& Wilson, C. (2014a). Chapter 25: Policies for Energy Technology Innovation. In Energy Technology Innovation: Learning from Historical Successes and Failures (pp. 371387). Cambridge University Press.

Grubler, A., \& Wilson, C. (2014b). Energy Technology Innovation: Learning from Historical Successes and Failures. Cambridge University Press.

Hannon, M., Diemen, R. Van, \& Skea, J. (2017). Examining the effectiveness of support for UK wave energy innovation since 2000.

Hekkert, M. P., Suurs, R. A. A., Negro, S. O., Kuhlmann, S., \& Smits, R. E. H. M. (2007). Functions of innovation systems: A new approach for analysing technological change. Technological Forecasting and Social Change, 74(4), 413-432. https://doi.org/10.1016/j.techfore.2006.03.002 
Hekkert, \& Negro, S. (2009). Functions of innovation systems as a framework to understand sustainable technological change: Empirical evidence for earlier claims. Technological Forecasting and Social Change, 76(4), 584-594. https://doi.org/10.1016/j.techfore.2008.04.013

Hu, R., Skea, J., \& Hannon, M. (2017). Measuring the effectiveness of energy innovation systems: an indicator framework and a case study of wind energy in China. Technological Forecasting and Social Change, (September 2016), 0-1. https://doi.org/10.1016/j.techfore.2017.09.025

Hu, Rui, Skea, J., \& Hannon, M. J. (2018). Measuring the energy innovation process: An indicator framework and a case study of wind energy in China. Technological Forecasting and Social Change, 127, 227-244. https://doi.org/10.1016/j.techfore.2017.09.025

Hudson, L., Winskel, M., \& Allen, S. (2011). The hesitant emergence of low carbon technologies in the UK: the micro-CHP innovation system. Technology Analysis \& Strategic Management, 23(3), 297-312. https://doi.org/10.1080/09537325.2011.550396

IEA. (2011). Good practice policy framework for energy technology research, development and demonstration $(R D \& D)$.

Jacobsson, S., Bergek, A., \& Sandén, B. (2017). Improving the European Commission's analytical base for designing instrument mixes in the energy sector: Market failures versus system weaknesses. Energy Research and Social Science, 33(November), 11-20. https://doi.org/10.1016/j.erss.2017.09.009

Jacobsson, S., \& Karltorp, K. (2013). Mechanisms blocking the dynamics of the European offshore wind energy innovation system - Challenges for policy intervention. Energy Policy, 63, 11821195. https://doi.org/10.1016/j.enpol.2013.08.077

Joliff-Botrel, G. (2015). New SET Plan Governance SET-Plan - meeting with stakeholders 5 October 2015. Brussels, Belgium: European Commission (EC).

Kern, F., \& Howlett, M. (2009). Implementing transition management as policy reforms: A case study of the Dutch energy sector. Policy Sciences, 42(4), 391-408. https://doi.org/10.1007/s11077009-9099-x

Klitkou, A., Borup, M., \& Iversen, E. (2012). Energy Innovation Systems: Indicator Report 2012.

Little, D. (2015). Mechanisms and Method. Philosophy of the Social Sciences, 45(4-5), 462-480. https://doi.org/10.1177/0048393115580420

Lundvall, B. A. (1992). National Systems of Innovation: Toward a Theory of Innovation and Interactive Learning. London: Pinter Publishers.

Markard, J. (2018). The life cycle of technological innovation systems. Technological Forecasting and Social Change, (July), 1-16. https://doi.org/10.1016/j.techfore.2018.07.045

Markowitz, H. M. (1952). Portfolio Selection. Journal of Finance, 7, 77-91.

Markowitz, H. M. (1959). Portfolio Selection: Efficient Diversification of Investments. New York: Wiley. 
McCollum, D. L., Wilson, C., Bevione, M., Carrara, S., Edelenbosch, O. Y., Emmerling, J., ... van Vuuren, D. P. (2018). Interaction of consumer preferences and climate policies in the global transition to low-carbon vehicles. Nature Energy, 3(8), 664-673. https://doi.org/10.1038/s41560-018-0195-z

Miremadi, I., Saboohi, Y., \& Jacobsson, S. (2016). Adapting Innovation Indicators to Assess Performance of Energy Innovation Systems : A Framework and Categorization of Indicators.

Morrow, W. R., Gallagher, K. S., Collantes, G., \& Lee, H. (2010). Analysis of policies to reduce oil consumption and greenhouse-gas emissions from the US transportation sector. Energy Policy, 38(3), 1305-1320. https://doi.org/10.1016/j.enpol.2009.11.006

Nelson, R. R. (1993). National Innovation Systems: A Comparative Analysis. Oxford University Press.

Nemet, G. F., Jakob, M., Steckel, J. C., \& Edenhofer, O. (2017). Addressing policy credibility problems for low-carbon investment. Global Environmental Change, 42, 47-57. https://doi.org/10.1016/j.gloenvcha.2016.12.004

OECD. (2015). System Innovation: Synthesis Report.

Park, M. S., Han, K., Jang, E., Choi, W., \& Joo, J. (2016). ASEM Eco-innovation Index 2016.

Pasimeni, F. (2017). EU energy technology trade: Import and export. Luxembourg. https://doi.org/10.2760/607980

Speirs, J., Pearson, P., \& Foxon, T. (2008). Adapting Innovation Systems Indicators to assess EcoInnovation. DIME working paper (Vol. 44). Retrieved from www.dimeeu.org/files/\%0Aactive/0/Foxon_Speirs_Pearson_final.pdf

Truffer, B., Markard, J., Binz, C., \& Jacobsson, S. (2012). Energy Innovation Systems-Structure of an emerging scholarly field and its future research directions. EIS Radar Paper.

Weber, K. M., \& Rohracher, H. (2012). Legitimizing research, technology and innovation policies for transformative change. Research Policy, 41(6), 1037-1047. https://doi.org/10.1016/j.respol.2011.10.015

Weyant, J. P. (2011). Accelerating the development and diffusion of new energy technologies: Beyond the "valley of death." Energy Economics, 33(4), 674-682. https://doi.org/10.1016/j.eneco.2010.08.008

Wieczorek, A. J., \& Hekkert, M. P. (2012). Systemic instruments for systemic innovation problems: A framework for policy makers and innovation scholars. Science and Public Policy, 39(1), 74 87. https://doi.org/10.1093/scipol/scr008

Wilson, C., Grubler, A., Gallagher, K. S., \& Nemet, G. F. (2012). Marginalization of end-use technologies in energy innovation for climate protection. Nature Climate Change, 2(11), 780788. https://doi.org/10.1038/nclimate1576

Wilson, C., \& Kim, Y. J. (2018). Technology-specific Analysis of Energy Innovation Systems. The 
Global Innovation Index 2018. In Global Innovation Index 2018: Energizing the World with Innovation (pp. 115-126). Ithaca, Fontainebleau, and Geneva, World Intellectual Property Organisation (WIPO), Cornell University, INSEAD and WIPO: Cornell University, INSEAD, and WIPO. Retrieved from https://www.globalinnovationindex.org/home

Woolthuis, R. K., Lankhuizen, M., \& Gilsing, V. (2005). A system failure framework for innovation policy design. Technovation, 25(6), 609-619.

https://doi.org/10.1016/j.technovation.2003.11.002

Zubaryeva, A., Dilara, P., \& Maineri, L. (2015). Publicly funded research, development and demonstration projects on electric and plug-in vehicles in Europe.

https://doi.org/10.2790/271951 


\section{Appendix A. Construction of each indicator in our framework applied at the EU level across six technology fields}

This section explains more in detail about the ETIS framework and how we construct each indicator. Each indicator is constructed directionally so that a higher score indicates 'better' or 'more' innovation activity. Additionally, we use a combination of absolute and relative indicators, which provide a very detail picture of the element in the Energy Technology Innovation System (ETIS) dimension being observed. For example, the absolute amount of research, development and demonstration (RD\&D) expenditure is considered as an input of knowledge generation while the ratio of the amount of RD\&D expenditure to Gross Domestic Product (GDP) describes financial resource mobilisation.

There is certainly some ambiguity as to which innovation system process is described by a particular indicator. In some cases, we develop variations of indicators to match different processes. For example, R\&D \$ in absolute terms is an indicator of knowledge generation (Wilson \& Kim, 2018), but R\&D \$ per unit of GDP in relative terms is an indicator of resource mobilisation (Wilson \& Kim, 2018) as it describes how much of the total available resource is channelled into innovation (in competition with other applications).

In all other cases, we follow precedent from the literature. For example, we assign international flows of patenting and publication to the knowledge dimension as the international dimension to knowledge generation and exchange was identified as a critical element in energy innovation for climate change mitigation (Grubler \& Wilson, 2014). As another example, we assign learning-by-using indicators in the 'users and markets' dimension (Klitkou, 2012).

\subsection{Knowledge Dimension}


The first dimension of the ETIS framework is knowledge (top of Figure 1). Knowledge generation, exchange and utilisation are engines of innovation. Scientific knowledge is generated by research and development. Knowledge can be codified as patents, blueprints, and publications, so it is readily transferable to related sectors of the economy (B. A. Lundvall, 1992; Von Hippel, 1998). Tacit knowledge is disseminated between people and is less easy to quantify (Von Hippel, 1998). Less formal knowledge can also flow in a process of interactive learning through a wide variety of mechanisms: networks of scientists and engineers, training, interactions and workshops (Kamp et al., 2004; Jacobsson et al., 2017). Knowledge flows occur at multiple scales from intra-firm up to inter-national, and can also 'spill over' between industries, sectors and domains of application (Nelson, 2009). However, both formal and informal knowledge stocks can also be depreciated through staff turnover, business volatility or technological obsolescence (Grubler \& Nemet, 2014).

Public energy RD\&D expenditure and demonstration budgets. $\mathrm{RD} \& \mathrm{D}$ is the most readily available measure of knowledge generation. We used public energy RD\&D expenditure including demonstration budgets from the International Energy Agency (IEA) RD\&D database.

Publications and patents. Common measures of codified knowledge include publications and patents. We counted the number of relevant publications in 2015 using keywords search on the Web of Science Core Collection (Popp, 2015; Popp, 2016; Stojkoska \& Trivodaliev, 2016; Belter \& Seidel, 2013; Rizzi et al., 2014; Cindrella et al., 2017; Tsay, 2008; Yesil-Celiktas, 2014; Sanz-Casado et al., 2014). The Web of Science publication data is frequently used to analyse scientific articles (Popp, 2017) as a research area of bibliometrics. Its easiness of use makes it widely used, but English language bias may exist (Gallagher et al., 2011). 
We counted the number of relevant patent applications in 2015 using Cooperative Patent Classifications (CPCs) from the U.S. Patent and Trademark Office (USPTO) $)^{1}$ (Haščič et al., 2015). The patent application date is an indicator of keeping track of the knowledge codification. We provide further details of both search methods in the Appendix B.

To control for quality of patents and publications, we use imperfect, but useful forward citation information on patent and publication datasets. So we count the number of patents (publications) weighted by the number of subsequent citations that the patent (publication) receive (Hall et al., 2005). There is a time lag between patent applications and patent grant dates because the patent office holds patent data confidential until announcing their award. So, there is a significant truncation issue regarding the number of patent applications, particularly in 2015 . The patent application data contain utility, design, plant, and reissue patents, but we only consider utility patents that are an invention of the process, the machine, or manufacturing parts.

Publication co-authorship and patent co-inventions (intra-extra). We used patent and publication datasets to identify intra-EU and extra-EU collaborative activities. We defined Intra-extra- EU collaboration as 1 if any inventors (authors) from intra-EU countries who collaborated with extra-EU countries, otherwise 0 . Once again, we considered a single inventor or author as a non-collaboration.

Energy technology imports. We used imports of related goods and Extra-EU collaboration in patenting and publication as a measure of knowledge spillover into the EU energy innovation system. We obtained data on the total import of energy technologies from EU trade data since 1988 by Harmonised System (HS) $6 .{ }^{2}$ We used the HS codes to attribute

\footnotetext{
${ }^{1}$ USPTO's PatentsView database: http://www.patentsview.org/web/\#viz/relationships

${ }^{2}$ https://data.europa.eu/euodp/en/data/dataset/PApkoFg8zsTS5CyokPyQ 
the import data to the different SET-Plan priority areas (United Nations et al., 2015;

Pasimeni, 2017). On the contrary, we identified Extra-EU collaboration as 1 if any inventors (authors) from EU countries who collaborated with non-EU countries, otherwise 0 . On a side note, we considered a single inventor or author as a 0 .

Volatility in energy $R D \& D$ expenditure. Knowledge depreciates more rapidly in stop-go environments associated with staff turnover and investment volatility. We calculated the volatility of energy RD\&D expenditure based on earlier work on market volatility (Czarnitzki $\&$ Toole, 2011) applied using a method from the economics of energy innovation (Kalamova et al., 2012; Verdolini et al., 2015). For the comparability of other indicators, we used the inverse of the coefficient of variation so that lower volatility results in a higher score on the indicator:

$$
P V_{i, t}=\frac{1}{\text { Coefficient of Variation }_{i, t}}=\frac{1}{\text { Policy Volatility }_{i, t}}=\frac{\frac{1}{5} \sum_{k=0}^{4} R D \& D_{i, t-k}}{{\sqrt{\frac{1}{5} \sum_{k=0}^{4}\left[R D \& D_{i, t-k}-\left(\frac{1}{5} \sum_{k=0}^{4} R D \& D_{i, t-k}\right)\right.}}^{2}}
$$

(1)

with $i$ as a country, $t$ as a year, and $k=0-4$ (lagged year).

\subsection{Resources \& Policies Dimension}

The second dimension of the ETIS framework is resources \& policies (left of Figure 1). Public investments in RD\&D play an important role in directly supporting energy innovation, and can exert a leveraging effect on private sector resource mobilisation. Policy instruments which increase returns on innovation investments (technology-push) and support market demand for innovation outcomes (market-pull) are an important institutional feature of innovation systems (Horbach et al., 2012; Peters et al., 2012; Rennings, 2000). Policy instruments have specific strengths and weaknesses, and opportunities for complementarity as well as conflict. Portfolios or mixes of policy instruments respond to a diverse set of 
technical, political, institutional and economic uncertainties and constraints (Flanagan et al., 2011; Grubb et al., 2017). A comprehensive mix of policy instruments may include technology-push, market-pull, and systemic instruments (which address innovation system failures such as weak actor networks) (Costantini et al., 2017), as well as instruments of different types (e.g., regulation, market-based, and RD\&D), and both technology-neutral and technology-specific instruments (Rosenow et al., 2017). Durability and stability in the policy environment provide clear signals to innovators and reduce regulatory risk (Barradale, 2009; Löfgren et al., 2008; Johnstone, 2011). Conversely, regulatory capture by firms and other interests vested in the incumbent system signals resistance to change in the institutional environment (Dasgupta et al., 2017).

Public energy RD\&D expenditure as \% of GDP. We divided public energy RD\&D expenditure by GDP. This is a normalised indicator across 28 EU countries.

Top 100 clean-tech funds. As simple measures of institutional capacity, we used data on the R\&D funding ${ }^{3}$ in each of the SET-Plan priority areas from a survey of the top 100 cleantech R\&D organisations in the EU collected by the European Commission. (Where data were not available for 2015, we used the most recent year for which data were available). This single indicator only partially describes 'capacity of actors \& institutions' as an innovation system process. Further research is required to construct datasets for measuring other indicators relevant to institutional capacity.

Patent activity as \% of total patents. We divided the number of patent per SET Plan technology field by total number of patents. This is a normalised indicator that shows a relative knowledge accumulation of a technology field.

\footnotetext{
${ }^{3}$ https://i3connect.com/gct100/the-list 
Policy density. Research on induced innovation in economics provides robust evidence of the effectiveness of public policy as a determinant of low-carbon technologies (Acemoglu, 2002; Acemoglu et al., 2012; Hicks, 1932). Traditionally, there are several ways to deal with policy instrument variables. First, a policy variable is coded as 1 if adopted any of the country and a zero otherwise (Carley, 2009; Johnstone et al., 2010). One caveat of this approach is to ignore the heterogeneity of policy instruments. To overcome this, one may measure policy stringency of the instruments which is not an easy task. In the Porter Hypothesis literature in economics, they traditionally used private pollution abatement costs and expenditures (PACE) as a proxy variable for the stringency of policies. However, it is vulnerable to endogeneity issues because the PACE is a measure of policy response rather than the policy itself (Dennis Dlugosch \& Koźluk, 2017). So often, energy prices have been used widely to proxy for climate change mitigation policies because energy prices are statistically significantly correlated with the stringency of environmental policies (Aldy \& Pizer, 2014). Second, many scholars have recently used a concept of the policy mix, a combination of policy instruments into a single composite index (Costantini et al., 2017). For example, several empirical studies used a density of policy instruments by calculating the total number of policies in place (Schaffrin et al., 2014, 2015). Additionally, we can use durability, stability and diversity of policy instrument which will be discussed more in detail in the following section to proxy for various aspects of the policy environment.

We used the International Energy Agency (IEA)'s policies and measures databases ${ }^{4}$ to compile information on a wide variety of policy instruments. We chose the "Addressing

\footnotetext{
${ }^{4}$ IEA Addressing Climate Change Database

https://www.iea.org/policiesandmeasures/climatechange/
}

Please note that there are four databases in the IEA Policies \& Measures Databases: Addressing Climate Change Database, IEA/IRENA Global Renewable Energy Policies and Measure Database, 
Climate Change" database because this database contains generic energy and climate change policies to reduce greenhouse gas emissions. IEA member countries regularly update this database. Within the EU, there are about 773 policy instruments in the database. To validate our database, we used the London School of Economics (LSE) Climate Change Laws of the World database. The overall trend of the introduction of a new policy introduction is similar to the IEA's Addressing Climate Change database, but a detailed comparison between two databases is not possible due to coverage issues. The common finding at the EU level is that there is a sharp decline in the number of policies after 2009. This trend is in part because of a greater centralisation of EU competence in clean energy and climate change policy fields (Rayner \& Jordan, 2016). For example, we observed saturation of policies over time, so 28 different national instruments were supplemented by one EU regulation.

Then, we distinguished policy instruments within the six SET-Plan areas from those in the non-SET-Plan areas using keywords. We categorized four types of policy instruments: innovation (e.g., RD\&D funding), market-based (e.g., grant and subsidies), regulatory (e.g., standards), and overarching policy instruments like roadmaps, plans, frameworks, targets (e.g., the EU's 20:20:20 targets). Note that this construction ignores the qualitative characteristics of policy instruments like the stringency of policy which are critical to the rate and direction of technological change (Taylor et al., 2005). It is a clear limitation of our approach, but the focus of this study is to measure the policy environment, which supports resource capacity of the energy technology innovation system.

Energy Efficiency Database, and Building Energy Efficiency Policies (BEEP) Database. We decided to only rely on the Addressing Climate Change Database because it is the most comprehensive database among others. Alternatively, we may use four databases altogether, but we need to have an appropriate strategy to deal with duplication issues. 
We developed three sets of indicators describing the density (number of policies active in any given year, in any given technology field), durability (cumulative length of time that policies have been in place in any given year, in any given technology field), and diversity of policy instruments within each SET-Plan priority area. For each technology field, we used the policy density indicator as a measure of policy support. We used the policy durability indicators to measure the stability of the policy over time. Policy diversity indicator is measuring whether there is broad-based policy support.

The policy density indicator is measuring how many policy instruments in place within a given technology field in each year, defined as:

$$
\text { Density }_{2015, p, s}=\left[\sum_{i=1}^{n} 1\right]_{p, s}
$$

with $i$ as one policy instrument $(i=1, \ldots \ldots, \mathrm{n}), p$ as types of policy instrument ( $\mathrm{p}=$ innovation, market-based and regulatory) and $s$ as SET-Plan priority area $(s=1, \ldots, 6)$.

Policy durability. The policy durability indicators are based on the cumulative length of policies in place in a particular technology field in each year, defined as:

$$
\text { Durability }_{2015, s, p}=\frac{\sum_{i=1}^{n}\left(2015_{s, p}-\text { Startyear }_{i, s, p}\right)}{n_{s, p}}
$$

with $i$ as one policy instrument $(i=1, \ldots ., \mathrm{n})$, startyear as a year of policy introduction, $p$ as types of policy instrument ( $\mathrm{p}=$ innovation, market-based and regulatory) and $s$ as SET-Plan priority area $(\mathrm{s}=1, \ldots, 6)$.

Policy diversity. The policy diversity indicator measures whether different types of policy instrument are well-balanced within each of the six SET-Plan priority areas (Negro \& Hekkert, 2010; Negro et al., 2012). The notion of "policy mix" is emphasised in energy, 
environmental economics and innovation literature (Lehmann, 2012; Rogge \& Reichardt, 2016; Schmidt \& Sewerin, 2018). Building on the energy literature (Kruyt et al., 2009; Mccollum et al., 2011), we used a statistical measure of diversity applied to the types of policy instruments, i.e., Shannon's diversity index H (sometimes Shannon-Weiner or Shannon-Wiener index):

$$
H_{s}=-\sum_{i} p_{i} \ln p_{i}
$$

with $p_{i}$ as share of a type of policy instrument in the SET-Plan priority area. The higher the value of $H$, the more diverse the mix of policy instruments.

Policy Stability. As an aggregate measure of policy stability, we divided the cumulative duration of all policy instruments by the total number of times policies had been changed, also using data from the IEA's Addressing Climate Change Database. Higher scores on the indicator denote fewer changes to policy instruments overall and so greater stability:

$$
\text { Stability }_{s}=\frac{\sum_{i=1}^{n}\left(2015_{s, p}-\text { Startyear }_{i, s, p}\right)}{n_{s, p} \times \text { No.of revisions }}
$$

with $i$ as one policy instrument $(i=1, \ldots \ldots, n)$, startyear as a year of policy introduction and $s$ as SET-Plan priority area $(\mathrm{s}=1, \ldots, 6)$.

Public RD\&D expenditure on fossil fuels. We collected public spending on fossil fuels from the IEA RD\&D database.

\subsection{Actors \& Networks Dimension}

The third dimension of the ETIS framework is actors \& networks (bottom of Figure 1). Heterogeneous actors with different technological knowledge and resource availability play differentiated roles in energy innovation (Charles \& Johnson, 1997; Lundvall, 2007). Private 
firms, government organisations, non-profit organisations and entrepreneurs can all participate and interact at different stages of the innovation lifecycle (Wieczorek \& Hekkert, 2012). Interactions between innovation actors helps generate and exchange knowledge, align expectations, and build advocacy coalitions (Carlsson \& Stankiewicz, 1991). Strong and shared expectations are important to reduce the uncertainty of energy innovation processes. Conversely, the legacy of a failure (e.g., consumer backlash, technology failure) can undermine confidence, erode policy attention, and divert mobilised resources (Anadon \& Nemet, 2014).

\section{Diversity of types of organisation in publication and patenting activity. We rely on} traditional data sets (e.g., publication and patent data). For publication and patent data, we categorized a type of organisations ${ }^{5}$, followed by assignee type in the USPTO data. Similarly, we identified the classification of the organisation using the Patent Name-Matching Project ${ }^{6}$ corporate and non-corporate assignee name standardization routines. For example, corporates include words such as "INC" and "CORP." Non-corporates are individuals, university, hospital, institutions, and government. Similarly, we attempted to identify university by looking for words such as "UNIV." Although we heavily rely on the existing STATA do files, it is inevitable that we carried out a certain amount of manual labour to identify remaining assignee names by searching online so that we could minimize errors and identify country-specific terms. Higher scores a more heterogeneous mix of actors in the energy innovation system:

${ }^{5}$ Classification of assignees: firm, individual, government, hospital, institution, university, others, none

${ }^{6} \mathrm{https} / / / \mathrm{eml}$. berkeley.edu/ bhhall/pat/namematch.html 


$$
E_{s}=-\sum_{s} q_{s} \ln q_{s}
$$

(6)

with $q_{s}$ as the share of SET-Plan priority area $s$ in the entire SET-Plan.

Diversity of types of organisation in research organisations. To capture the broader spectrum of actors involved in energy innovation activities beyond traditional data sets (e.g., patents, publications), we measured the Shannon's diversity index H using the European Energy Research Alliance (EERA). ${ }^{7}$

Publication co-authorship and patent co-inventions (intra-intra). We used patent and publication datasets to identify intra-EU and intra-EU collaborative activities. We defined Intra-EU collaboration as 1 if any inventors (authors) from EU countries who collaborated with EU countries, otherwise 0. Once again, we considered a single inventor or author as a non-collaboration.

Research collaborations (intra-intra). we counted the number of actors and organisations participating and interacting within the European Energy Research Alliance (EERA).

Policy target density and durability. Targets and roadmaps developed collaboratively by key stakeholders are important indications of shared expectations (OECD, 2015). We calculated both the density and durability of strategic goals, targets, roadmaps, action plans following the method set out above for other types of policy instruments (using the IEA's Addressing Climate Change Database). Someone might argue that targets, roadmaps and action plans can be categorized as policy instruments because it comes from the same

${ }^{7} \mathrm{https} / /$ setis.ec.europa.eu/implementation/technology-roadmap/european-energy-researchalliance-eera 
database, but we considered them as a process of formulating shared expectations which help "guide the search" of actors within the innovation system.

Decline in interest following a failure. Innovation failure can have long-lasting effects on the market and regulatory confidence. As no prior measure exists in the literature, we developed a new indicator by fitting a decay function to Google search data following a peak of interest linked to a well-publicised failure. Google trend data grabbed a lot of attention in economics literature to forecast near-term economic indicators (Choi \& Varian, 2012). We reasoned that rapid decay in interest is a crude measure of a legacy of failure. First, we identified a well-known 'failure' for each technology in each SET-Plan priority area (e.g., Fukushima nuclear accident for Nuclear Safety $)^{8}$. We then used Google Trends $^{9}$ to identify search frequencies using technology keywords. ${ }^{10}$ We searched trends in all categories globally. We then fitted decay function to search frequencies following peak interest during the failure. For the indicator, we use the inverse of the decay function coefficient so that a higher score indicates slow or no dissipation of public interest (and so lower legacy of failure):

$$
\begin{gathered}
Y_{t, s}=A \times e^{-b_{s} \times t} \\
\operatorname{Ln}\left(Y_{s, t}\right)=-b_{s} \times t \\
\operatorname{Coeff}_{s}=\frac{1}{b_{s}}
\end{gathered}
$$

\footnotetext{
${ }^{8}$ The high-profile innovation 'failures' in technologies across the SET-Plan priority areas from
} which point we estimated decay functions in Google Search interest are: RE: Solyndra bankruptcy (Sept. 2011), SG: Smart grid backlash in the Netherlands (April, 2009), EE: Cancellation of the UK Green Deal (July, 2015), ST: Roadster failure (June, 2008), CCS: Several CCS cancellations (April, 2009), NP: Fukushima nuclear accident (March, 2011)

${ }^{9} \mathrm{https} / /$ trends.google.co.uk/trends/

${ }^{10}$ RE: renewable energy, SG: the smart grid, EE: the green deal, ST: electric vehicle, CCS: carbon capture and storage, NP: nuclear power 
with $t$ as year and $s$ as SET-Plan priority area $(\mathrm{s}=1, \ldots, 6)$.

\subsection{Users \& Markets Dimension}

The fourth dimension of the ETIS framework is users \& markets (right of Figure 1). The importance of users tends to be under-emphasised in other innovation system frameworks. However, consumers are not just passive users of technologies but are also active participants in energy innovation (Schot et al., 2016). Consumers' preferences and experiences with an innovation as it gains market share provides feedback from real-world application and use. The accumulation of knowledge and experience (learning-by-doing) is a key pathway for improving production processes and technology performance, as well as decreasing costs (Junginger et al., 2010; Rubin et al., 2015; Yu \& Gibbs, 2018). Perceptions of the potential market size for an innovation can reinforce the shared expectations of innovation actors to stimulate and guide innovation activity.

Learning. Learning describes cost reductions and performance improvements as a function of cumulative experience. Learning rates are a simple measure of the $\%$ reduction in cost per doubling of cumulative capacity or production. We sourced learning rates per technology from existing literature (Nilsson \& Nykvist, 2016; Rubin et al., 2015; Weiss et al., 2010). As learning rates are estimated from time-series data, these are not 2015 crosssectional data, and so not directly commensurate with our other indicators.

Potential Market Size. Potential market size is a measure of expectation and demand-pull for innovations. We used numerous data sources to estimate the potential market size of technologies in each SET-Plan priority area. To ensure comparability across areas, we expressed market size in $€$ terms, converting from physical units using average $€$ /unit estimates (Table A1). 
Market Share. We used data on actual market penetration of technologies in each SETPlan priority area to estimate market share relative to the potential market size estimated for the previous indicator (Table A1). The market share indicator for 'Nuclear Safety' as a priority area measures the share of nuclear power in the electricity mix rather than the share of safe reactors and fuel cycles (which is assumed and hoped to be 100\%).

Table A1. Estimates of Potential and Actual Market Size in Six SET-Plan Priority Areas in 2015

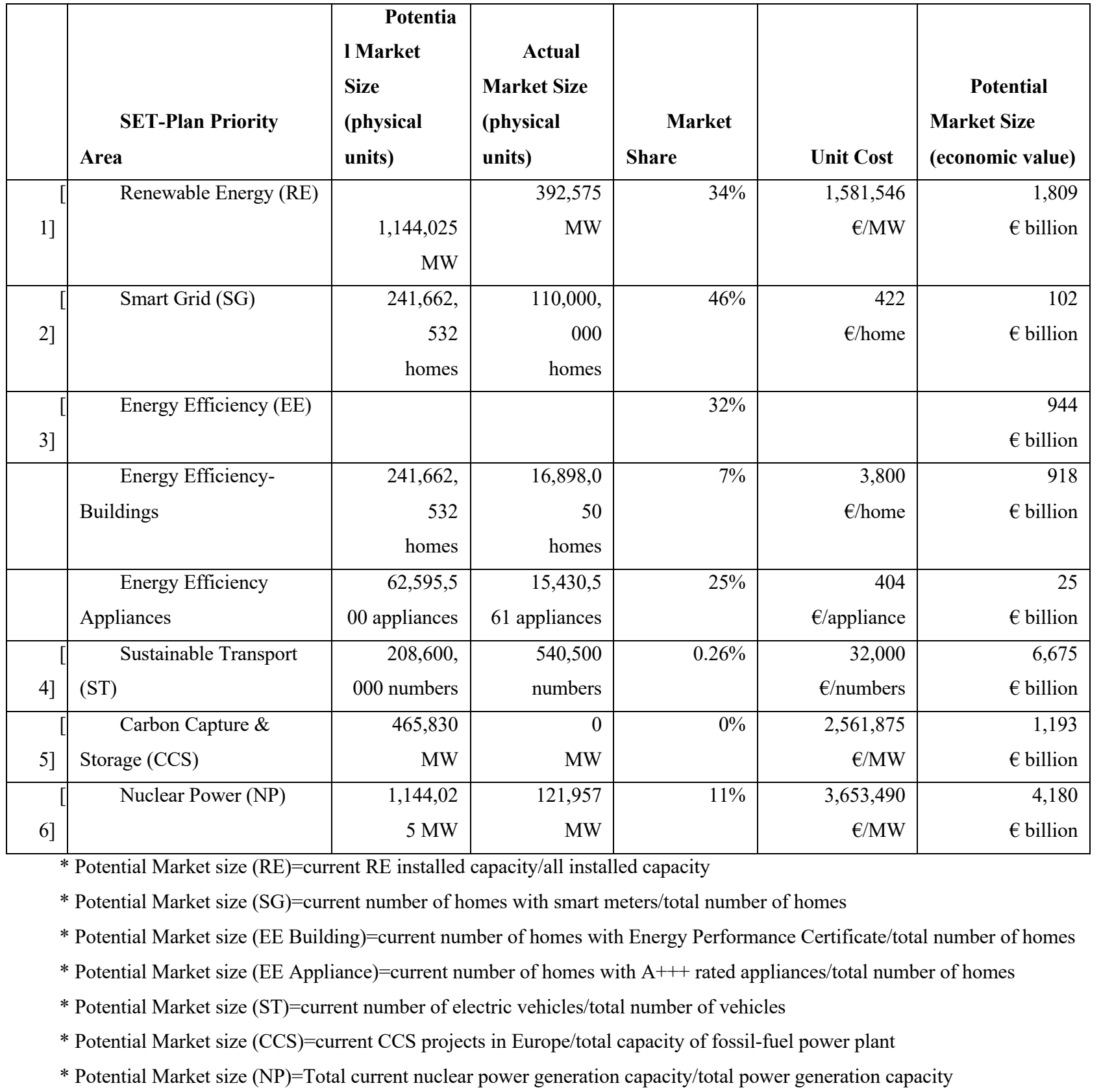


* Note that the scope of technology fields in sustainable transport is narrower than other dimensions of the ETIS framework.

\section{References}

Acemoglu, D. (2002). Directed Technical Change. Review of Economic Studies, 69(4), 781809. https://doi.org/10.1111/1467-937X.00226

Acemoglu, D., Aghion, P., Bursztyn, L., \& Hemous, D. (2012). The Environment and Directed Technical Change: Comment. Am Econ Rev, 102(1), 131-166.

https://doi.org/10.1257/aer.102.1.131

Aldy, J., \& Pizer, W. (2014). Comparability of Effort in International Climate Policy Architecture. Harvard Project on Climate .... Retrieved from http://belfercenter.hks.harvard.edu/files/dp62_aldy-pizer.pdf

Anadon, L. D., \& Nemet, G. F. (2014). The U.S. Synthetic Fuels Corporation: Policy Consistency, Flexibility, and the Long-Term Consequences of Perceived Failures. In A. Grubler \& C. Wilson (Eds.), Energy Technology Innovation: Learning from Historical Successes and Failures (pp. 257-272). Cambridge: Cambridge University Press. https://doi.org/DOI: 10.1017/CBO9781139150880.025

Barradale, M. J. (2009). Impact of Public Policy Uncertainty on Renewable Energy Investment: Wind Power and the PTC (USAEE WP 08-003). Energy Policy (Vol. 38). Elsevier. https://doi.org/10.1016/J.ENPOL.2010.08.021

Belter, C. W., \& Seidel, D. J. (2013). A bibliometric analysis of climate engineering research. WIREs Clim Change, 4(October), 417-427. https://doi.org/10.1002/wcc.229

Carley, S. (2009). State renewable energy electricity policies: An empirical evaluation of effectiveness. Energy Policy, 37(8), 3071-3081. https://doi.org/10.1016/j.enpol.2009.03.062

Carlsson, B., \& Stankiewicz, R. (1991). On the nature, function and composition of technological systems. Journal of Evolutionary Economics, 1(2), 93-118. https://doi.org/10.1007/BF01224915

Charles, E., \& Johnson, B. (1997). Institutions and organizations in systems of innovation. London: Pinter Publishers.

Choi, H., \& Varian, H. (2012). Predicting the Present with Google Trends. Economic Record, 88, 2-9. https://doi.org/10.1111/j.1475-4932.2012.00809.x 
Cindrella, L., Fu, H., \& Ho, Y. (2017). Global thrust on fuel cells and their sustainability - an assessment of research trends by bibliometric analysis. International Journal of Sustainable Energy, 6451(June). https://doi.org/10.1080/14786451.2012.755185

Costantini, V., Crespi, F., \& Palma, A. (2017a). Characterizing the policy mix and its impact on eco-innovation: A patent analysis of energy-efficient technologies. Research Policy, 46(4), 799-819. https://doi.org/10.1016/j.respol.2017.02.004

Costantini, V., Crespi, F., \& Palma, A. (2017b). Characterizing the policy mix and its impact on eco-innovation in energy- efficient technologies Characterizing the policy mix and its impact on eco- innovation in energy-efficient technologies. Research Policy, 46(4), 799-819. https://doi.org/10.1016/j.respol.2017.02.004

Czarnitzki, D., \& Toole, A. A. (2011). Patent Protection, Market Uncertainty, and R\&D Investment. The Review of Economics and Statistics, 93(1), 147-159.

Dasgupta, S., Cian, E. De, \& Verdolini, E. (2017). The Political Economy of Energy Innovation. In The Political Economy of Clean Energy Transitions (Vol. 1, pp. 1-38). Oxford University Press. https://doi.org/10.1093/oso/9780198802242.001.0001

Dennis Dlugosch, \& Koźluk, T. (2017). Energy prices, environmental policies and investment: evidence from listed firms (Working Party on Integrating Environmental and Economic Policies ENERGY). Retrieved from http://www.oecd.org/officialdocuments/publicdisplaydocumentpdf/?cote=ENV/EPOC/ WPIEEP(2016)16/FINAL\&docLanguage $=$ En

Flanagan, K., Uyarra, E., \& Laranja, M. (2011). Reconceptualising the "policy mix" for innovation. Research Policy, 40(5), 702-713. https://doi.org/10.1016/j.respol.2011.02.005

Gallagher, K. S., Anadon, L. D., Kempener, R., \& Wilson, C. (2011). Trends in investments in global energy research, development, and demonstration. Wiley Interdisciplinary Reviews: Climate Change, 2(3), 373-396. https://doi.org/10.1002/wcc.112

Grubb, M., McDowall, W., \& Drummond, P. (2017). On order and complexity in innovations systems: Conceptual frameworks for policy mixes in sustainability transitions. Energy Research \& Social Science, 33, 21-34. https://doi.org/10.1016/J.ERSS.2017.09.016

Grubler, A., \& Nemet, G. F. (2014). Sources and Consequences of Knowledge Depreciation. In Energy Technology Innovation: Learning from Historical Successes and Failures (pp. 133-145).

Grubler, A., \& Wilson, C. (2014). Energy Technology Innovation: Learning from Historical 
Successes and Failures. Cambridge University Press.

Hall, B. H., Jaffe, A., \& Trajtenberg, M. (2005). Market value and patent citations. RAND Journal of Economics, 36(1), 16-38. Retrieved from http://www.jstor.org/stable/1593752

Haščič, I., Silva, J., \& Johnstone, N. (2015). The Use of Patent Statistics for International Comparisons and Analysis of Narrow Technological Fields.

Hicks, J. R. (1932). The Theory of Wages. London: MacMillan.

Horbach, J., Rammer, C., \& Rennings, K. (2012). Determinants of eco-innovations by type of environmental impact — The role of regulatory push/pull, technology push and market pull. Ecological Economics, 78, 112-122. https://doi.org/10.1016/j.ecolecon.2012.04.005

Jacobsson, S., Bergek, A., \& Sandén, B. (2017). Improving the European Commission's analytical base for designing instrument mixes in the energy sector: Market failures versus system weaknesses. Energy Research and Social Science, 33(November), 11-20. https://doi.org/10.1016/j.erss.2017.09.009

Johnstone, N. (2011). Invention and Transfer of Environmental Technologies. OECD Studies on Environmental Innovation Invention and Transfer of Environmental Technologies. Retrieved from http://books.google.com/books?hl=en\&amp;lr=\&amp;id=GR64Agm_eqkC\&amp;oi=fn d\&amp;pg=PA235\&amp;dq=Invention+and+Transfer+of+Environmental+Technologie s\&amp;ots=cbzsKAH-DL\&amp;sig=mo6Blk8YAitcWd3m8J8WaHuC-ss

Johnstone, N., Haščič, I., \& Popp, D. (2010). Renewable Energy Policies and Technological Innovation: Evidence Based on Patent Counts. Environmental and Resource Economics, 45(1), 133-155. https://doi.org/10.1007/s10640-009-9309-1

Junginger, M., Lako, P., Lensink, S., \& Van Sark, W. (2010). Technological Learning in the Energy Sector: Lessons for Policy. Industry and Science. Cheltenham, UK: Edward Elgar. Retrieved from http://igitur-archive.library.uu.nl/chem/2009-0306201752/UUindex.html

Kalamova, M., Johnstone, N., \& Haščič, I. (2012). Implications of Policy Uncertainty for Innovation in Environmental Technologies: The Case of Public R\&D Budgets. In V. Costantini (Ed.), The Dynamics of Environmental and Economic Systems: Innovation, Environmental Policy and Competitiveness (pp. 83-95). Springer.

https://doi.org/10.1007/978-94-007-5089-0 
Kamp, L. M., Smits, R. E. H. M., \& Andriesse, C. D. (2004). Notions on learning applied to wind turbine development in the Netherlands and Denmark. Energy Policy, 32(14), 1625-1637. https://doi.org/https://doi.org/10.1016/S0301-4215(03)00134-4

Kruyt, B., van Vuuren, D. P., de Vries, H. J. M., Groenenberg, H., Vuuren, D. P. Van, Vries, H. J. M. De, \& Groenenberg, H. (2009). Indicators for energy security. Energy Policy, 37(6), 2166-2181. https://doi.org/10.1016/j.enpol.2009.02.006

Lehmann, P. (2012). Justifying a policy mix for pollution control: a review of economic literature. Journal of Economics Surveys, 26(1), 71-97. https://doi.org/10.1111/j.14676419.2010.00628.x

Löfgren, Å., Millock, K., \& Nauges, C. (2008). The effect of uncertainty on pollution abatement investments: Measuring hurdle rates for Swedish industry. Resource and Energy Economics, 30(4), 475-491. https://doi.org/10.1016/j.reseneeco.2008.09.002

Lundvall, B. A. (1992). National Systems of Innovation: Toward a Theory of Innovation and Interactive Learning. London: Pinter Publishers.

Lundvall, B. Å. (2007). National innovation systems - Analytical concept and development tool. Industry and Innovation, 14(1), 95-119. https://doi.org/10.1080/13662710601130863

McCollum, D. L., Krey, V., \& Riahi, K. (2011). An integrated approach to energy sustainability. Nature Climate Change, 1(9), 428-429. https://doi.org/10.1038/nclimate1297

Negro, S. O., Alkemade, F., \& Hekkert, M. P. (2012). Why does renewable energy diffuse so slowly? A review of innovation system problems. Renewable and Sustainable Energy Reviews, 16(6), 3836-3846. https://doi.org/10.1016/j.rser.2012.03.043

Negro, S. O., \& Hekkert, M. P. (2010). Overcoming typical failures in the emergence of sustainable innovation systems - The need for a new form of innovation policy. In Energy transitions in an interdependent world: what and where are the future social science research agenda? SPRU, University of Sussex, UK.

Nelson, A. J. (2009). Measuring knowledge spillovers: What patents, licenses and publications reveal about innovation diffusion. Research Policy, 38(6), 994-1005. https://doi.org/10.1016/j.respol.2009.01.023

Nilsson, M., \& Nykvist, B. (2016). Governing the electric vehicle transition ??? Near term interventions to support a green energy economy. Applied Energy, 179, 1360-1371. https://doi.org/10.1016/j.apenergy.2016.03.056 
OECD. (2015). System Innovation: Synthesis Report.

Pasimeni, F. (2017). EU energy technology trade: Import and export. Luxembourg. https://doi.org/10.2760/607980

Peters, M., Schneider, M., Griesshaber, T., \& Hoffmann, V. H. (2012). The impact of technology-push and demand-pull policies on technical change - Does the locus of policies matter? Research Policy, 41(8), 1296-1308.

https://doi.org/10.1016/j.respol.2012.02.004

Popp, D. (2015). Government R\&D Spending : The Case of Energy (No. 5442).

Popp, D. (2017). From science to technology: The value of knowledge from different energy research institutions. Research Policy, 46(9), 1580-1594. https://doi.org/10.1016/j.respol.2017.07.011

Rayner, T., \& Jordan, A. (2016). Climate Change Policy in the European Union. Oxford University Press.

Rennings, K. (2000). Redefining innovation - Eco-innovation research and the contribution from ecological economics. Ecological Economics, 32(2), 319-332.

https://doi.org/10.1016/S0921-8009(99)00112-3

Rizzi, F., van Eck, N. J., \& Frey, M. (2014). The production of scientific knowledge on renewable energies: Worldwide trends, dynamics and challenges and implications for management. Renewable Energy, 62, 657-671. https://doi.org/10.1016/j.renene.2013.08.030

Rogge, K. S., \& Reichardt, K. (2016). Policy mixes for sustainability transitions : An extended concept and framework for analysis. Research Policy, 45(8), 1620-1635. https://doi.org/10.1016/j.respol.2016.04.004

Rosenow, J., Kern, F., \& Rogge, K. (2017). The need for comprehensive and well targeted instrument mixes to stimulate energy transitions: The case of energy efficiency policy. Energy Research and Social Science, 33(March), 95-104. https://doi.org/10.1016/j.erss.2017.09.013

Rubin, E. S., Azevedo, I. M. L., Jaramillo, P., \& Yeh, S. (2015). A review of learning rates for electricity supply technologies. Energy Policy, 86, 198-218.

https://doi.org/10.1016/j.enpol.2015.06.011

Sanz-Casado, E., Lascurain-Sánchez, M. L., Serrano-Lopez, A. E., Larsen, B., \& Ingwersen, P. (2014). Production, consumption and research on solar energy Sanz-Casado, Renewable Energy, 68, 733-744. https://doi.org/10.1016/j.renene.2014.03.013 
Schaffrin, A., Sewerin, S., \& Seubert, S. (2014). The innovativeness of national policy portfolios - climate policy change in Austria, Germany, and the UK. Environmental Politics, 23(5), 860-883. https://doi.org/10.1080/09644016.2014.924206

Schaffrin, A., Sewerin, S., \& Seubert, S. (2015). Toward a Comparative Measure of Climate Policy Output. Policy Studies Journal, 43(2), 257-282.

https://doi.org/10.1111/psj.12095

Schmidt, T. S., \& Sewerin, S. (2018, March 30). Measuring the temporal dynamics of policy mixes - An empirical analysis of renewable energy policy mixes' balance and design features in nine countries. Research Policy, p. 103557. https://doi.org/10.1016/j.respol.2018.03.012

Schot, J., Kanger, L., \& Verbong, G. (2016). The roles of users in shaping transitions to new energy systems. Nature Energy, 1(5), 16054. https://doi.org/10.1038/nenergy.2016.54

Stojkoska, B. L. R., \& Trivodaliev, K. V. (2016). A review of Internet of Things for smart home: Challenges and solutions. Journal of Cleaner Production.

Taylor, M. R., Rubin, E. S., \& Hounshell, D. a. (2005). Regulation as the mother of innovation: The case of SO 2 control. Law and Policy, 27(2), 348-378. Retrieved from http://www.scopus.com/inward/record.url?eid=2-s2.020344376982\&partnerID=40\&md5=dad787887a8cca35ee13b1deaaa1651 1

Tsay, M.-Y. (2008). A bibliometric analysis of hydrogen energy literature,1965-2005. Scientometrics, 75(3), 421-438. https://doi.org/10.1007/s11192-007-1785-x

United Nations, Office, E. P., \& Dechezleprêtre, A. (2015). Climate change mitigation technologies in Europe - evidence from patent and economic data.

Verdolini, E., Bosetti, V., \& Jockers, P. (2015). The impact of policy and uncertainty on innovation in the wind industry : evidence from European countries. Green Growth Knowledge Platform (GGKP) Third Annual Conference.

Von Hippel, E. (1998). The Sources of Innovation. Oxford University Press. https://doi.org/10.1007/978-3-8349-9320-5_10

Weiss, M., Junginger, M., Patel, M. K., \& Blok, K. (2010). A review of experience curve analyses for energy demand technologies. Technological Forecasting and Social Change, 77(3), 411-428. https://doi.org/10.1016/j.techfore.2009.10.009

Wieczorek, A. J., \& Hekkert, M. P. (2012). Systemic instruments for systemic innovation problems: A framework for policy makers and innovation scholars. Science and Public Policy, 39(1), 74-87. https://doi.org/10.1093/scipol/scr008 
Wilson, C., \& Kim, Y. J. (2018). Technology-specific Analysis of Energy Innovation Systems. The Global Innovation Index 2018. In Global Innovation Index 2018: Energizing the World with Innovation (pp. 115-126). Ithaca, Fontainebleau, and Geneva, World Intellectual Property Organisation (WIPO), Cornell University, INSEAD and WIPO: Cornell University, INSEAD, and WIPO. Retrieved from https://www.globalinnovationindex.org/home

Yesil-Celiktas, O. (2014). Patenting trends in enzyme related microfluidic applications. Biochemical Engineering Journal, 92, 53-62. https://doi.org/10.1016/j.bej.2014.06.017

Yu, Z., \& Gibbs, D. (2018). Social ties, homophily and heterophily in urban sustainability transitions: User practices and solar water heater diffusion in China. Energy Research \& Social Science, 46, 236-244. https://doi.org/10.1016/J.ERSS.2018.07.029 


\section{Appendix B. Methods and additional results}

\section{Scope of data search to match SET Plan priority areas}

Data corresponding to each of the six priority areas of the SET Plan were identified either by searching databases using author-defined search terms per priority area (e.g., publications in Web of Science) or by allocating database-defined categories to priority areas (e.g., RD\&D investments in IEA database). Wherever possible, the scope or breadth of data corresponding to each priority area was kept consistent across all the indicators (Table B4). The aim was to maximise consistency of scope across indicators to ensure comparability.

Table B4. Matching of Scope of Data for ETIS Indicators to SET Plan Priority Areas. Text in italics shows main deviations from SET Plan Priority Areas.

\begin{tabular}{|c|c|c|c|}
\hline & & SET Plan priority area & Target Scope of Data for ETIS indicators \\
\hline 1 & $\mathrm{RE}$ & $\begin{array}{l}\text { Renewable energy \& } \\
\text { system integration }\end{array}$ & $\begin{array}{l}\text { all renewable energy (exc. fuels) (exc. } \\
\text { stationary storage) }\end{array}$ \\
\hline 2 & $\mathrm{SG}$ & Smart technologies \& grid & $\begin{array}{l}\text { all grid and power systems (inc. stationary } \\
\text { storage) (exc. smart homes) }\end{array}$ \\
\hline 3 & $\mathrm{EE}$ & $\begin{array}{l}\text { Energy efficiency in } \\
\text { buildings \& industry }\end{array}$ & $\begin{array}{l}\text { all energy efficiency in buildings and } \\
\text { industry }\end{array}$ \\
\hline 4 & ST & $\begin{array}{l}\text { Sustainable transport (EVs, } \\
\text { renewable fuels) }\end{array}$ & $\begin{array}{l}\text { all alternative fuels and vehicles (inc. } \\
\text { mobile storage) (inc. all } \mathrm{H}_{2} \text { ) }\end{array}$ \\
\hline 5 & $\mathrm{CCS}$ & $\begin{array}{l}\text { Carbon capture }+ \text { storage } \\
\text { or use }\end{array}$ & $\begin{array}{l}\text { all carbon capture (from large point } \\
\text { sources), storage \& use }\end{array}$ \\
\hline 6 & NP & Nuclear power & all nuclear fission and fusion (inc. safety) \\
\hline
\end{tabular}

Some inconsistencies were unavoidable due to differences in database structure or in the database-defined categories. In these cases, it was not possible to match the scope of the SET Plan priority area to the scope of the data for all indicators. As a result, a 'lowest-common denominator' approach to defining the scope of data was adopted to ensure consistency across all indicators. The main resulting mismatches between scope of data and scope of SET Plan priority areas were: 
- SG (Smart Grid) data over-estimates activity as includes all 'non-smart' grid and power systems, but under-estimates activity as doesn't include smart technologies \& homes as consumer products;

- ST (Sustainable Transport) over-estimates activity as includes all $\mathrm{H}_{2}$ as fuel which may be for stationary applications and/or non-renewable;

- NP (Nuclear Power) over-estimates activity as includes all nuclear-related activity (not limited to safety).

Based on the target scope of data for all ETIS indicators defined in Table B4, specific sets of search terms and/or category allocations were used for the different databases used for each indicator. The resulting scopes of data are summarised in Table B5, with the main inconsistencies shown in italics. Similarly, Table B3 includes the scope of data collected for ETIS Indicators on each SET Plan priority area in learning rates, legacy of failures, market size and market share. It also includes events and time span for estimating a decay function of the legacy of failure from the Google Trend data.

The remainder of this appendix includes additional details on data-collection methods. Table B4 shows the category of the IEA public RD\&D expenditure and SET-Plan priority areas respectively. Table B5 includes search queries of the publication data. Similarly, for the construction of the patent data, Table B6 includes IPC classes to identify SET-Plan priority patents. Table B7 shows harmonized system (HS) codes of low carbon goods. Table B8 shows STATA commands that will enable readers to replicate the policy instrument data processing. Table B9 shows the estimation results of the decay function. Finally, Table B10 includes methods of calculating potential and actual market size in SET-Plan priority areas.

Table B5. Scope of Data Collected for ETIS Indicators on each SET Plan Priority Area. Text in italics shows main inconsistencies (see table B2 footnotes for details).

\begin{tabular}{|c|l|l|l|l|l|}
\hline & $\begin{array}{c}\text { knowledge } \\
\text { generation }\end{array}$ & $\begin{array}{c}\text { knowledge } \\
\text { codification }\end{array}$ & $\begin{array}{c}\text { knowledge } \\
\text { codification }\end{array}$ & $\begin{array}{c}\text { knowledge } \\
\text { spillover }\end{array}$ \\
\hline & $\begin{array}{c}\text { Target } \\
\text { Scope (see } \\
\text { Table B4) }\end{array}$ & $\begin{array}{c}\text { IEA } \\
\text { RD\&D \$ }\end{array}$ & $\begin{array}{l}\text { Web of } \\
\text { Science } \\
\text { publications }\end{array}$ & $\begin{array}{c}\text { Patent } \\
\text { CPC }\end{array}$ & $\begin{array}{l}\text { Harmonised } \\
\text { System (HS } \\
\text { codes }\end{array}$ \\
\hline RE & $\begin{array}{l}\text { all } \\
\text { renewable } \\
\text { energy: }\end{array}$ & $\begin{array}{l}\text { Solar, } \\
\text { wind, geo, } \\
\text { ocean, hydro, }\end{array}$ & $\begin{array}{l}\text { solar } \\
\text { thermal, solar } \\
\text { PV, wind, }\end{array}$ & $\begin{array}{l}\text { Solar } \\
\text { thermal, solar } \\
\text { PV, wind, }\end{array}$ & $\begin{array}{l}\text { Solar } \\
\text { thermal, solar } \\
\text { PV, wind, }\end{array}$ \\
\hline
\end{tabular}




\begin{tabular}{|c|c|c|c|c|c|}
\hline & $\begin{array}{l}\text { solar, wind, } \\
\text { geo, wave, } \\
\text { marine, } \\
\text { ocean, } \\
\text { hydro, } \\
\text { bioenergy } \\
\text { (exc. fuels) } \\
\text { (exc. } \\
\text { storage) }\end{array}$ & $\begin{array}{l}\text { other } \\
\text { renewable } \\
\text { sources } \\
\text { (exc. Fuels, } \\
\text { biofuels, } \\
\text { storage) }\end{array}$ & $\begin{array}{l}\text { geothermal, } \\
\text { ocean, hydro, } \\
\text { bio energy } \\
\text { (exc. Fuels, } \\
\text { biofuels, } \\
\text { storage) }\end{array}$ & $\begin{array}{l}\text { geothermal, } \\
\text { marine, hydro, } \\
\text { integration } \\
\text { technologies } \\
\text { (exc. fuels) } \\
\text { (exc. storage) }\end{array}$ & $\begin{array}{l}\text { bioenergy, } \\
\text { ocean, wave, } \\
\text { marine, } \\
\text { geothermal, } \\
\text { hydro } \\
\text { (exc. fuels) } \\
\text { (exc. storage) }\end{array}$ \\
\hline $\mathrm{SG}$ & $\begin{array}{l}\text { all grid } \\
\text { and power } \\
\text { systems } \\
\text { (inc. } \\
\text { stationary } \\
\text { storage, } \\
\text { exc. smart } \\
\text { homes) }\end{array}$ & $\begin{array}{l}\text { all grid and } \\
\text { power systems } \\
\text { (inc. storage, } \\
\text { exc. vehicle } \\
\text { storage) }\end{array}$ & $\begin{array}{l}\text { all grid and } \\
\text { power systems, } \\
\text { smart } \\
\text { technologies } \\
\text { and grids (inc. } \\
\text { storage, exc. } \\
\text { vehicle } \\
\text { storage) }\end{array}$ & $\begin{array}{l}\quad \text { all grid and } \\
\text { power } \\
\text { systems, smart } \\
\text { grids (inc. } \\
\text { storage, exc. } \\
\text { vehicle } \\
\text { storage) }\end{array}$ & $\begin{array}{l}\quad \text { electricity } \\
\text { meters, smart } \\
\text { grids } \\
\quad \text { (inc. storage } \\
\text { exc. vehicle } \\
\text { storage) }\end{array}$ \\
\hline $\mathrm{EE}$ & $\begin{array}{l}\quad \text { all } \\
\text { energy } \\
\text { efficiency } \\
\text { in buildings } \\
\text { and } \\
\text { industry }\end{array}$ & $\begin{array}{l}\text { energy } \\
\text { efficiency } \\
\text { (buildings, } \\
\text { industry) }\end{array}$ & $\begin{array}{l}\text { energy } \\
\text { efficiency } \\
\text { (buildings, } \\
\text { industry) }\end{array}$ & $\begin{array}{l}\text { energy } \\
\text { efficiency } \\
\text { (buildings, } \\
\text { industry) }\end{array}$ & $\begin{array}{l}\text { thermostats, } \\
\text { heat } \\
\text { exchangers, } \\
\text { insulation, } \\
\text { lighting, EE in } \\
\text { heavy industry } 1\end{array}$ \\
\hline ST & \begin{tabular}{l}
\multicolumn{1}{c}{ all } \\
alternative \\
fuels and \\
vehicles \\
(inc. mobile \\
storage) \\
(inc. all \\
H2)
\end{tabular} & $\begin{array}{l}\text { EV, mobile } \\
\text { (vehicle) } \\
\text { storage, H2, } \\
\text { fuel cells, } \\
\text { biofuel }\end{array}$ & $\begin{array}{l}\text { biofuels, } \\
\text { EVs, FCVs } \\
\text { H2, vehicle } \\
\text { storage }\end{array}$ & $\begin{array}{l}\text { biofuels, } \\
\text { EVs, FCVs, } \\
\text { H2, hybrid } \\
\text { vehicle, } \\
\text { vehicle } \\
\text { storage, } \\
\text { charging } \\
\text { stations and }\end{array}$ & $\begin{array}{l}\text { EVs, energy } \\
\text { storage(mobile), } \\
\text { biofuels, } \\
\text { batteries } 2\end{array}$ \\
\hline
\end{tabular}




\begin{tabular}{|c|c|c|c|c|c|}
\hline & & & & $\begin{array}{l}\text { enabling } \\
\text { technologies }\end{array}$ & \\
\hline CCS & $\begin{array}{l}\quad \text { all } \\
\text { carbon } \\
\text { capture } \\
\text { (from large } \\
\text { point } \\
\text { sources), } \\
\text { storage \& } \\
\text { use }\end{array}$ & $\begin{array}{l}\text { all carbon } \\
\text { capture (from } \\
\text { anthropogenic } \\
\text { point sources) }\end{array}$ & $\begin{array}{l}\text { all carbon } \\
\text { capture and } \\
\text { storage }\end{array}$ & $\begin{array}{l}\text { all carbon } \\
\text { capture and } \\
\text { storage }\end{array}$ & $\begin{array}{c}\text { CCS } \\
\text { surveying } \\
\text { equipment } 3\end{array}$ \\
\hline $\mathrm{NP}$ & \begin{tabular}{l}
\multicolumn{1}{c}{ all } \\
nuclear \\
fission and \\
fusion (inc. \\
safety)
\end{tabular} & $\begin{array}{l}\text { all nuclear } \\
\text { fission and } \\
\text { fusion, and } \\
\text { other generic } \\
\text { nuclear }\end{array}$ & $\begin{array}{l}\text { all nuclear } \\
\text { fission and } \\
\text { fusion (inc. } \\
\text { safety) }\end{array}$ & $\begin{array}{l}\text { all nuclear } \\
\text { fission and } \\
\text { fusion }\end{array}$ & $\begin{array}{l}\text { nuclear } \\
\text { reactors } 4\end{array}$ \\
\hline
\end{tabular}

1 under-estimates activity as includes only specific subsets of energy efficiency in buildings \& industry 2 under-estimates activity as excludes $\mathrm{H} 2$ and other alternative fuels than biofuels and EVs

3 strongly under-estimates activity as includes only a specific type of CCS equipment (for surveying)

4 under-estimates activity as includes only reactors and not componentry or balance of plants 
Table B3. Scope of Data Collected for ETIS Indicators on each SET Plan Priority Area.

Text in italics shows main inconsistencies (see table B3 footnotes for details).

\begin{tabular}{|c|c|c|c|c|c|}
\hline & & & \multicolumn{2}{|c|}{ Resources } & \multirow{2}{*}{$\begin{array}{c}\begin{array}{c}\text { Adoption } \\
\text { and Use }\end{array} \\
\text { Market } \\
\text { size/market } \\
\text { share }\end{array}$} \\
\hline & $\begin{array}{r}\text { Target } \\
\text { Scope (see } \\
\text { Table B4) }\end{array}$ & $\begin{array}{r}\text { Learning } \\
\text { Rates (2015) }\end{array}$ & $\begin{array}{l}\text { Legacy of } \\
\text { failures }\end{array}$ & $\begin{array}{l}\text { Legacy of } \\
\text { failures } \\
\text { Events and } \\
\text { date }\end{array}$ & \\
\hline $\mathrm{RE}$ & \begin{tabular}{l}
\multicolumn{1}{c}{ all } \\
renewable \\
energy: \\
solar, \\
wind, geo, \\
wave, \\
marine, \\
ocean, \\
hydro, \\
bioenergy \\
(exc. \\
fuels) \\
(exc. \\
storage)
\end{tabular} & $\begin{array}{l}\quad \text { Solar PV, } \\
\text { wind, } \\
\text { bioenergy, } \\
\text { hydro } 1\end{array}$ & $\begin{array}{l}\text { Renewable } \\
\text { energy }\end{array}$ & $\begin{array}{l}\text { Solyndra } \\
\text { bankruptcy } \\
\text { (Sept. 2011) }\end{array}$ & $\begin{array}{l}\text { Solar, wind, } \\
\text { geo, hydro }\end{array}$ \\
\hline $\mathrm{SG}$ & $\begin{array}{l}\text { all grid } \\
\text { and power } \\
\text { systems } \\
\text { (inc. } \\
\text { stationary } \\
\text { storage, } \\
\text { exc. smart } \\
\text { homes) }\end{array}$ & Smart grid & Smart grid & $\begin{array}{l}\text { Smart grid } \\
\text { backlash in the } \\
\text { Netherlands } \\
\text { (April 2009) }\end{array}$ & Smart meter \\
\hline
\end{tabular}




\begin{tabular}{|c|c|c|c|c|c|}
\hline $\mathrm{EE}$ & \begin{tabular}{l}
\multicolumn{1}{c}{ all } \\
energy \\
efficiency \\
in \\
buildings \\
and \\
industry
\end{tabular} & $\begin{array}{l}\quad \text { Washing } \\
\text { machines, } \\
\text { laundry driers, } \\
\text { dishwashers, } \\
\text { Refrigerators, } \\
\text { Freezers } 2\end{array}$ & Green deal & $\begin{array}{l}\text { Cancellation } \\
\text { of the Green } \\
\text { Deal* (July } \\
2015 \text { ) }\end{array}$ & $\begin{array}{l}\text { Refrigerator, } \\
\text { washing } \\
\text { machine, } \\
\text { tumbler drier, } \\
\text { energy } \\
\text { efficiency } \\
\text { retrofit in } \\
\text { building } 2\end{array}$ \\
\hline ST & \begin{tabular}{l}
\multicolumn{1}{c}{ all } \\
alternative \\
fuels and \\
vehicles \\
(inc. \\
mobile \\
storage) \\
(inc. all \\
H2)
\end{tabular} & $\begin{array}{c}\text { Electric } \\
\text { vehicle battery }\end{array}$ & $\begin{array}{l}\text { Sustainable } \\
\text { transport }\end{array}$ & $\begin{array}{l}\text { Roadster } \\
\text { failure (June } \\
2008 \text { ) }\end{array}$ & $\begin{array}{l}\quad \text { All } \\
\text { alternative fuel } \\
\text { vehicles }\end{array}$ \\
\hline $\mathrm{CCS}$ & $\begin{array}{l}\quad \text { all } \\
\text { carbon } \\
\text { capture } \\
\text { (from } \\
\text { large point } \\
\text { sources), } \\
\text { storage \& } \\
\text { use }\end{array}$ & $\begin{array}{r}\mathrm{PC}+\mathrm{CCS}, \\
\mathrm{IGCC}+\mathrm{CCS}, \\
\mathrm{NGCC}+\mathrm{CCS}\end{array}$ & $\begin{array}{l}\text { Carbon } \\
\text { capture and } \\
\text { storage }\end{array}$ & $\begin{array}{c}\text { General } \\
\text { (April 2009) }\end{array}$ & $\begin{array}{l}\text { CCS current } \\
\text { projects in } \\
\text { Europe }\end{array}$ \\
\hline NP & \begin{tabular}{l}
\multicolumn{1}{c}{ all } \\
nuclear \\
fission and \\
fusion \\
(inc. \\
safety)
\end{tabular} & $\begin{array}{l}\text { Nuclear } \\
\text { power }\end{array}$ & $\begin{array}{l}\text { Nuclear } \\
\text { safety }\end{array}$ & $\begin{array}{l}\text { Fukushima } \\
\text { nuclear accident } \\
\text { (March 2011) }\end{array}$ & $\begin{array}{l}\text { Total power } \\
\text { generated from } \\
\text { nuclear }\end{array}$ \\
\hline
\end{tabular}

*Green deal is U.K. government policy to help homeowners and landlords invest in renewable energy and energy efficiency products. 
1. under-estimates activity as includes only solar PV, wind, bioenergy, and hydro energy.

2. under-estimates activity as includes only energy efficiency in buildings.

* Learning rates: RE: (Rubin et al., 2015), SG:

http://engineeringonline.ucr.edu/resources/infographic/future-of-smart-grid-technologies/

EE: (Weiss et al., 2010), ST: (Nilsson \& Nykvist, 2016), CCS: (Rubin et al., 2015), NP: (Rubin et al., 2015)

Table B4. IEA public RD\&D expenditure (Total RD\&D in Million Euro (2015 prices and exch. rates))

\begin{tabular}{|c|c|c|}
\hline Category & sub-category & $\begin{array}{l}\text { SET- } \\
\text { Plan } \\
\text { areas }\end{array}$ \\
\hline \multirow{2}{*}{\multicolumn{3}{|c|}{$\begin{array}{l}\text { GROUP 1: ENERGY } \\
\text { EFFICIENCY }\end{array}$}} \\
\hline & & \\
\hline 11 & Industry & 3 \\
\hline 12 & $\begin{array}{l}\text { Res. and comm. buildings, appliances and } \\
\text { equipment }\end{array}$ & 3 \\
\hline 13 & Transport & \\
\hline 1311 & Vehicle batteries/storage technologies & 4 \\
\hline 1312 & Advanced power elecs, motors, EV/HEV/FCV sys & 4 \\
\hline 1314 & Electric vehicle infrastructure & 4 \\
\hline 1315 & Fuel for on-road vehicles (excl. hydrogen) & 4 \\
\hline 14 & Other energy efficiency & \\
\hline 19 & Unallocated energy efficiency & \\
\hline \multicolumn{3}{|l|}{$\begin{array}{l}\text { GROUP 2: FOSSIL } \\
\text { FUELS }\end{array}$} \\
\hline 21 & Oil and gas & \\
\hline 22 & Coal & \\
\hline 23 & $\mathrm{CO} 2$ capture and storage & 5 \\
\hline 29 & Unallocated fossil fuels & \\
\hline $\begin{array}{l}\text { GROUP 3: } \\
\text { RENEWABLE ENERGY } \\
\text { SOURCES }\end{array}$ & & \\
\hline
\end{tabular}




\begin{tabular}{|c|c|c|}
\hline 31 & Solar energy & 1 \\
\hline 32 & Wind energy & 1 \\
\hline 33 & Ocean energy & 1 \\
\hline 34 & Biofuels (incl. liquids, solids and biogases) & 4 \\
\hline 35 & Geothermal energy & 1 \\
\hline 36 & Hydroelectricity & 1 \\
\hline 37 & Other renewable energy sources & 1 \\
\hline 39 & Unallocated renewable energy sources & 1 \\
\hline \multicolumn{3}{|l|}{ GROUP 4: NUCLEAR } \\
\hline 41 & Nuclear fission & 6 \\
\hline 42 & Nuclear fusion & 6 \\
\hline 49 & Unallocated nuclear & 6 \\
\hline \multicolumn{3}{|l|}{$\begin{array}{l}\text { GROUP 5: } \\
\text { HYDROGEN AND FUEL } \\
\text { CELLS }\end{array}$} \\
\hline 51 & Hydrogen & \\
\hline 511 & Hydrogen production & \\
\hline 512 & Hydrogen storage & 4 \\
\hline 513 & Hydrogen transport and distribution & \\
\hline 514 & Other infrastructure and systems & \\
\hline 515 & Hydrogen end-uses & \\
\hline 519 & Unallocated hydrogen & \\
\hline 52 & Fuel cells & 4 \\
\hline 59 & Unallocated hydrogen and fuel cells & 4 \\
\hline \multicolumn{3}{|l|}{$\begin{array}{l}\text { GROUP 6: OTHER } \\
\text { POWER AND STORAGE } \\
\text { TECHNOLOGIES }\end{array}$} \\
\hline 61 & Electric power conversion & \\
\hline 611 & Power generation technologies & \\
\hline 612 & Power generation supporting technologies & 2 \\
\hline 613 & Other electricity power generation & \\
\hline 619 & Unallocated electric power generation & \\
\hline
\end{tabular}




\begin{tabular}{|c|c|c|}
\hline 62 & Electricity transmission and distribution & 2 \\
\hline 63 & Energy storage & 2 \\
\hline 631 & Electrical storage & \\
\hline 632 & Thermal energy storage & \\
\hline 639 & Unallocated energy storage & \\
\hline 69 & Unallocated other power and storage techs. & 2 \\
\hline GROUP 7: OTHER & & \\
\hline CROSS-CUTTING & & \\
\hline TECHS/RESEARCH & & \\
\hline 71 & Energy system analysis & 2 \\
\hline 72 & Basic energy research not allocated & \\
\hline 73 & Other & \\
\hline GROUP 8: & & \\
\hline Unallocated & & \\
\hline
\end{tabular}

Table B5. Knowledge Codification: Search Queries of the Web of Science (Publication)

\begin{tabular}{|c|c|c|c|}
\hline $\begin{array}{r}\text { SE } \\
\text { T-Plan }\end{array}$ & $\begin{array}{l}\text { SET-Plan } \\
\text { sub technology } \\
\text { areas }\end{array}$ & Search Queries & Source \\
\hline 1 & $\begin{array}{l}\quad \text { All } \\
\text { renewables(gen } \\
\text { eral terms) }\end{array}$ & $\mathrm{TS}=($ renewable energ $*)$ & \\
\hline 1 & $\begin{array}{l}\text { Solar } \\
\text { thermal power }\end{array}$ & $\begin{array}{l}\quad \mathrm{TS}=(\text { solar NEAR/2 thermoelectr*) OR TS } \\
=(\text { solar NEAR/2 power plant) OR TS }= \\
\text { (concentrat* solar NEAR/2 power) OR TS= } \\
(\text { solar thermal NEAR/2 (power OR electric*)) } \\
\text { OR TS=(parabolic* NEAR/2 trough*) OR } \\
\text { TS=((parabolic NEAR/2 dish*) AND solar) } \\
\text { OR TS = (stirling NEAR/2 dish*) OR } \\
\text { TS=((Fresnel NEAR/2 (reflector* OR lens*)) } \\
\text { AND solar) OR TS=(solar NEAR/2 tower) }\end{array}$ & $\begin{array}{l}\text { Popp } \\
(2016)\end{array}$ \\
\hline
\end{tabular}




\begin{tabular}{|c|c|c|c|}
\hline 1 & $\begin{array}{c}\text { Solar } \\
\text { Photovoltaic }\end{array}$ & $\begin{array}{l}\text { TS = ("photovoltaic energ*" OR "solar } \\
\text { cell*" OR "photovoltaic power *" OR } \\
\text { "photovoltaic cell*" OR "photovoltaic solar } \\
\text { energy*" or "solar PV") }\end{array}$ & $\begin{array}{l}\text { Popp } \\
(2016)\end{array}$ \\
\hline 1 & $\begin{array}{l}\text { Wind } \\
\text { Energy }\end{array}$ & $\begin{array}{l}\text { TS = ("wind power" OR "wind energy" OR } \\
\text { "wind turbine*" OR "wind farm*" OR "wind } \\
\text { park*" OR "wind plant*") }\end{array}$ & $\begin{array}{l}\text { Popp } \\
(2016)\end{array}$ \\
\hline 1 & $\begin{array}{ll} & \text { geotheorma } \\
1 & \end{array}$ & $\mathrm{TS}=($ "geothermal") & $\begin{array}{l}\text { SanzCas } \\
\text { ado et al. } \\
(2014)\end{array}$ \\
\hline 1 & ocean & $\begin{array}{l}\text { TS=(“wave power" OR "wave energy*” } \\
\text { OR "wave convers*” OR "marine } \\
\text { energy" OR “ocean energy") }\end{array}$ & $\begin{array}{l}\text { SanzCas } \\
\text { ado et al. } \\
(2014)\end{array}$ \\
\hline 1 & hydro & $\mathrm{TS}=$ ("hydro power" or "hydroelectricity") & \\
\hline 1 & Bio energy & $\begin{array}{l}\text { TS=(“biomass" or "biomass energy" OR } \\
\text { "Bio feedstock*" OR "biofeedstock*" OR } \\
\text { "Hydrotreated vegetable oil*" or } \\
\text { "lignocellulosic biomass*” or "biomass to } \\
\text { liquid*") }\end{array}$ & \\
\hline 1 & $\begin{array}{c}\text { RE } \\
\text { Exclusion }\end{array}$ & NOT TS $=($ batte $*$ OR storage OR storing $)$ & \\
\hline 2 & $\begin{array}{l}\text { All grid and } \\
\text { power systems }\end{array}$ & $\begin{array}{l}\mathrm{TS}=(\text { ("efficient" and ("electrical power } \\
\text { gen*" or "power transmission*" or "power } \\
\text { distribu*")) }\end{array}$ & \\
\hline 2 & smart grid & $\begin{array}{l}\text { TS = (“Wireless Sensor Networks" OR } \\
\text { "Internet of Things" OR "IoT") OR TS = } \\
\text { ("Smart Home” OR "Home Automation") OR } \\
\text { TS = ("Smart Grid") OR } \\
\text { TS=(“demand side management" OR } \\
\text { "DSM") }\end{array}$ & $\begin{array}{l}\text { Stojkpsk } \\
\text { a et al. } \\
(2016)\end{array}$ \\
\hline
\end{tabular}




\begin{tabular}{|c|c|c|c|}
\hline 2 & $\begin{array}{l}\text { Power } \\
\text { generation } \\
\text { energy storage }\end{array}$ & $\begin{array}{l}\text { TS }=(\text { ("power gen*" and "energy storage") } \\
\text { OR } \\
\text { TS }=\text { ("power gen*" and "electrical } \\
\text { storage") OR } \\
\text { TS = ("power gen*" and "thermal energy } \\
\text { storage") }\end{array}$ & \\
\hline 3 & $\begin{array}{l}\quad \text { energy } \\
\text { efficiency in } \\
\text { buildings and } \\
\text { industry }\end{array}$ & $\begin{array}{l}\text { TS=("building energy effici*”) or } \\
\text { TS=(“energy efficien*” and "insulation") } \\
\text { OR } \\
\text { TS=(“energy efficien*” and "boiler") OR } \\
\text { TS=(“energy efficien*” and "furnace”) OR } \\
\text { TS = (("LED" OR "light emitting diode") } \\
\text { NEAR/1 (lighting OR lightbulb* OR "light } \\
\text { bulb*" OR lamp* OR "solid state light*” OR } \\
\text { "solid state lamp*”)) OR } \\
\text { TS = (("CFL" OR "compact fluorescent") } \\
\text { NEAR/1 (lighting OR } \\
\text { lightbulb* OR "light bulb*" OR lamp*)) OR } \\
\text { TS = ("solid state light*") OR } \\
\text { TS=(“energy efficien*” and "industry } \\
\text { process") }\end{array}$ & $\begin{array}{l}\text { Popp } \\
(2015)\end{array}$ \\
\hline 4 & Biofuels & $\begin{array}{l}\text { TS = ("biomass fuel*" OR "cellulosic } \\
\text { ethanol*" OR "bio synthetic gas*" OR "algae- } \\
\text { based fuel*" OR "Biohydrogen production*" or } \\
\text { "Biological hydrogen production*" or } \\
\text { "biofuel*" or "bio fuel*" or "biodiesel*" or } \\
\text { "bio diesel*" or "bio oil" or "bio ethanol*" or } \\
\text { "bioethanol*" OR "Biomethanol*" OR "bio } \\
\text { methanol*") }\end{array}$ & $\begin{array}{l}\text { Popp } \\
(2016)\end{array}$ \\
\hline 4 & $\begin{array}{l}\text { Vehicle } \\
\text { energy storage }\end{array}$ & $\begin{array}{l}\mathrm{TS}=(\text { "mobile energy storage" or "vehicle } \\
\text { batter*" or "vehicle storage") }\end{array}$ & $\begin{array}{l}\text { Celiktas } \\
(2009)\end{array}$ \\
\hline
\end{tabular}




\begin{tabular}{|c|c|c|c|}
\hline 4 & $\begin{array}{l}\text { electric } \\
\text { vehicle }\end{array}$ & $\mathrm{TS}=($ "electric vehicle") & $\begin{array}{l}\text { Hu et al. } \\
(2014)\end{array}$ \\
\hline 4 & $\begin{array}{l}\text { fuel cells } \\
\text { and hydrogen( } \\
\text { fuel cells are } \\
\text { the main } \\
\text { vehicle for the } \\
\text { application of } \\
\text { hydrogen } \\
\text { energy) }\end{array}$ & $\begin{array}{l}\text { TS=(“"Fuel cell*") or TS=("hydrogen } \\
\text { vehicle") }\end{array}$ & $\begin{array}{l}\text { Cindrella } \\
\text { et al. }(2014) \\
\text { Tsay (2008) }\end{array}$ \\
\hline 4 & $\begin{array}{l}\text { alternative } \\
\text { fuels }\end{array}$ & $\mathrm{TS}=$ (“alternative fuel*”) & $\begin{array}{l}\text { Rizzi et } \\
\text { al. (2014) }\end{array}$ \\
\hline 5 & $\begin{array}{l}\text { carbon } \\
\text { capture and } \\
\text { storage }\end{array}$ & $\begin{array}{l}\quad(\mathrm{TS}=((\text { "carbon" OR “CO2") and } \\
\text { "capture”) OR TS=(“carbon capture and } \\
\text { utili*”) or TS=(“CCS")) }\end{array}$ & $\begin{array}{l}\text { Belter } \\
(2013)\end{array}$ \\
\hline 6 & $\begin{array}{l}\text { nuclear } \\
\text { power }\end{array}$ & $\begin{array}{l}\text { TS=("nuclear safe*" or "safe nuclear" or } \\
\text { "nuclear power" or "nuclear fusion" or } \\
\text { "nuclear fission" or "nuclear reactor") }\end{array}$ & \\
\hline & $\begin{array}{l}\text { Country } \\
\text { restriction }\end{array}$ & $\begin{array}{l}\text { CU=(AUSTRIA or BELGIUM or } \\
\text { BULGARIA or CROATIA or CYPRUS or } \\
\text { CZECH REPUBLIC or DENMARK or } \\
\text { ESTONIA or FINLAND or FRANCE or } \\
\text { GERMANY or GREECE or HUNGARY or } \\
\text { IRELAND or ITALY or LATVIA or } \\
\text { LITHUANIA or LUXEMBOURG or MALTA } \\
\text { or NETHERLANDS or POLAND or } \\
\text { PORTUGAL or ROMANIA or SLOVAKIA or } \\
\text { SLOVENIA or SPAIN or SWEDEN or } \\
\text { ENGLAND or SCOTLAND or WALES or } \\
\text { NORTHERN IRELAND or United Kingdom) }\end{array}$ & \\
\hline
\end{tabular}

Source: (Belter \& Seidel, 2013; Cindrella et al., 2017; Hu et al., 2017; Popp, 2015; Popp, 2016; Rizzi et al., 2014; Sanz-Casado et al., 2014; Stojkoska \& Trivodaliev, 2016; Tsay, 2008; Yesil-Celiktas, 2014)

Table B6. Knowledge Codification: Patents 


\begin{tabular}{|c|c|c|}
\hline Technologies & CPC & $\begin{array}{l}\text { SET- } \\
\text { Plan }\end{array}$ \\
\hline $\begin{array}{l}\text { 4.1. Renewable energy generation } \\
\text {-wind energy } \\
\text {-Solar thermal energy } \\
\text {-Solar PV energy } \\
\text {-Solar thermal-PV hybrids } \\
\text {-Geothermal energy } \\
\text {-Marine energy } \\
\text {-Hydro energy }\end{array}$ & Y02E10 & 1 \\
\hline $\begin{array}{l}\text { 7.1. Integration of renewable energy sources in buildings } \\
\text {-Photovoltaic [PV]: Roof systems for PV cells; PV hubs } \\
\text {-Solar thermal: Evacuated solar collectors; Air conditioning or } \\
\text { refrigeration systems } \\
\text {-Wind power } \\
\text {-Geothermal heat-pumps } \\
\text {-Hydropower in dwellings } \\
\text {-Use of biomass for heating } \\
\text {-Hybrid systems; Uninterruptible or back-up power supplies } \\
\text { integrating renewable energies }\end{array}$ & Y02B10 & 1 \\
\hline $\begin{array}{l}\text { 4.5. Technologies for an efficient electrical power generation, } \\
\text { transmission or distribution } \\
\text { 4.5.1. Superconducting electric elements or equipment } \\
\text { Flexible AC transmission systems [FACTS] } \\
\text { Active power filtering [APF] } \\
\text { Reactive power compensation } \\
\text { Arrangements for reducing harmonics } \\
\text { Arrangements for eliminating or reducing asymmetry in polyphase } \\
\text { networks } \\
\text { Smart grids }\end{array}$ & Y02E40 & 2 \\
\hline 4.6.4. Smart grids in the energy sector & Y02E60/70 & 2 \\
\hline
\end{tabular}


4.7. Other energy conversion or management systems reducing GHG emissions

\subsubsection{Capacitors}

-Ultracapacitors, supercapacitors, double-layer capacitors

4.6.1.3. Thermal storage

-Sensible heat storage, Latent heat storage, Cold storage

4.6.1.4. Pressurised fluid storage

4.6.1.5. Mechanical storage

-Mechanical energy storage, e.g. flywheels

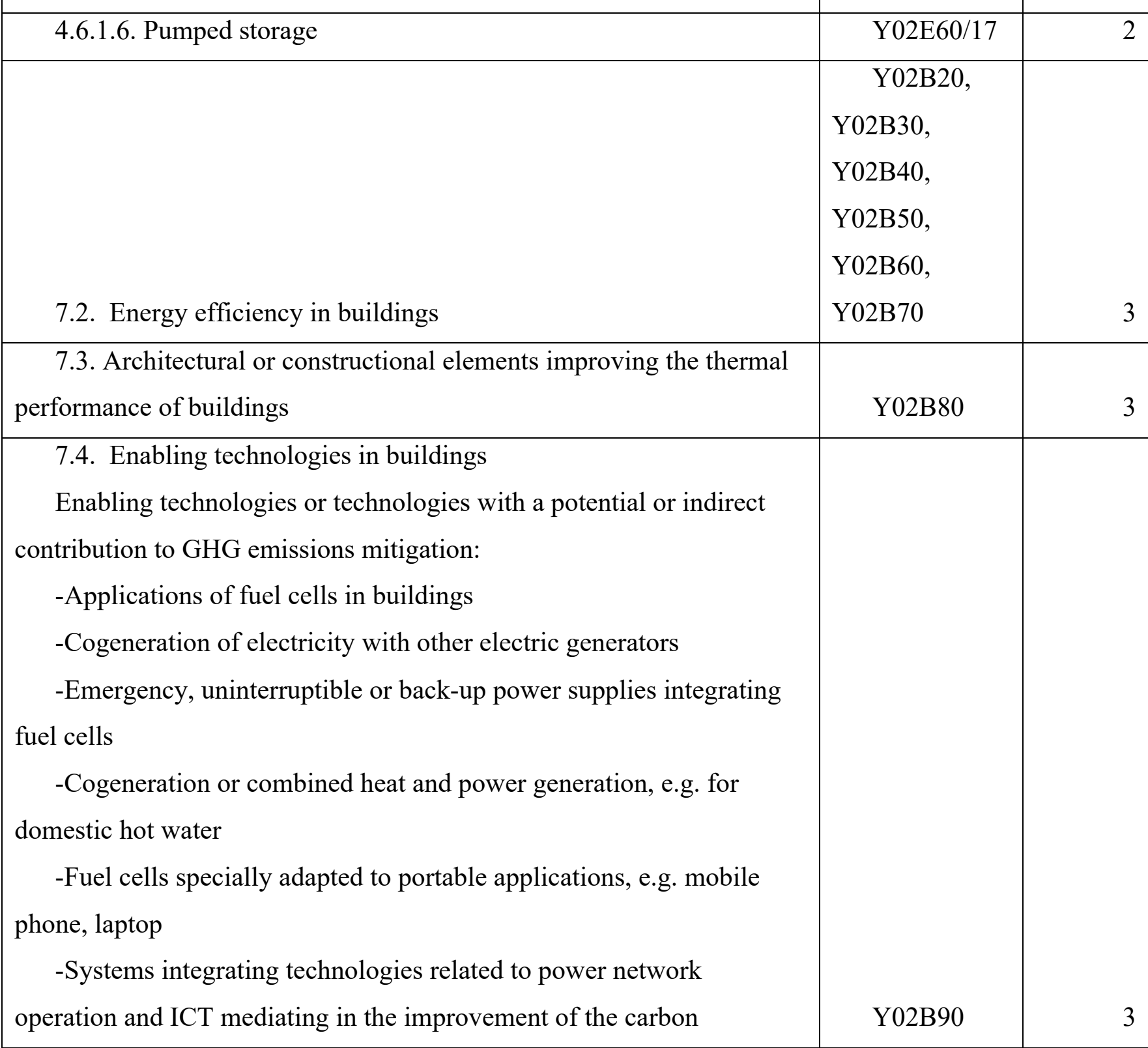


footprint of the management of residential or tertiary loads, i.e. smart grids as enabling technology in buildings sector (e.g.

related to uninterruptible power supply systems, remote reading systems, etc.)

4.3.1. Technologies for improved output efficiency (Combined heat and power, combined cycles, etc.)

Heat utilisation in combustion or incineration of waste

Combined heat and power generation [CHP]

Combined cycle power plant [CCPP], or combined cycle gas turbine [CCGT]

Integrated gasification combined cycle [IGCC]

4.3.2. Technologies for improved input efficiency (Efficient combustion or heat usage)

- Direct CO2 mitigation: Use of synair, i.e. a mixture of recycled $\mathrm{CO} 2$ and pure $\mathrm{O} 2$; Use of reactants before or during

combustion; Segregation from fumes, including use of reactants downstream from combustion or deep cooling; Controls

of combustion specifically inferring on $\mathrm{CO} 2$ emissions

- Indirect $\mathrm{CO} 2$ mitigation, i.e. by acting on non $\mathrm{CO} 2$ directly related matters of the process, e.g. more efficient use of fuels:

Cold flame; Oxyfuel combustion; Unmixed combustion; Air preheating

-Heat recovery other than air pre-heating: at fumes level, at burner level

4.2.1. Biofuels

-CHP turbines for biofeed; Gas turbines for biofeed

-Bio-diesel

-Bio-pyrolysis; Torrefaction of biomass

-Cellulosic bio-ethanol; Grain bio-ethanol; Bio-alcohols produced by other means than fermentation

4.6.1.1. Batteries

-Lithium-ion batteries

Y02E50/10

Y02E20/30366

Y02E60/12 
-Alkaline secondary batteries, e.g. NiCd or NiMH

-Lead-acid batteries

-Hybrid cells

4.6.2. Hydrogen technology

Hydrogen storage: Storage of liquefied, solidified, or compressed

hydrogen in containers; Storage in caverns; Reversible

uptake of hydrogen by an appropriate medium (e.g. carbon, metal, rare earth metal, metal alloy, organic compound)

-Hydrogen distribution

-Hydrogen production from non-carbon containing sources: by chemical reaction with metal hydrides, e.g. hydrolysis of

metal borohydrides; by decomposition of inorganic compounds, e.g. splitting of water other than electrolysis, ammonia borane; by electrolysis of water; by photo-electrolysis

\begin{tabular}{|c|c|c|}
\hline & & 4 \\
\hline & Y02E60/50- & \\
\hline 4.6.3. Fuel cells & 566 & 4 \\
\hline 6.1.2. Hybrid vehicles & Y02T10/62 & 4 \\
\hline 6.1.3. Electric vehicles & $\begin{array}{l}\text { Y02T10/64- } \\
649, \\
\text { Y02T10/70- } \\
7094, \\
\text { Y02T10/72- } \\
7291\end{array}$ & 4 \\
\hline $\begin{array}{l}\text { 6.5. Enabling technologies in transport } \\
\text {-Electric vehicle charging }\end{array}$ & & \\
\hline -Application of fuel cell and hydrogen technology to transportation & Y02T90 & 4 \\
\hline $\begin{array}{l}\text { Combined cycle power plant }[\mathrm{CCPP}] \text {, or combined cycle gas turbine } \\
\text { [CCGT] combined with carbon capture and storage }[\mathrm{CCS}]\end{array}$ & Y02E20/185 & 5 \\
\hline $\begin{array}{l}\text { 5.1. CO2 capture and storage (CCS) } \\
\text { - Capture by biological separation } \\
\text { - Capture by chemical separation } \\
\text { - Capture by absorption }\end{array}$ & $\mathrm{Y} 02 \mathrm{C} 10$ & 5 \\
\hline
\end{tabular}


- Capture by adsorption

- Capture by membranes or diffusion

- Capture by rectification and condensation

- Subterranean or submarine CO2 storage

4.4. Nuclear energy

-nuclear fusion reactors

-nuclear fission reactors

Source: (Haščič \& Migotto, 2015)

Table B7. Description and harmonised system (HS) codes of low carbon goods

\begin{tabular}{|c|c|c|c|}
\hline Technology class & $\begin{array}{l}\text { HS } \\
\text { code }\end{array}$ & Description & $\begin{array}{l}\text { SET- } \\
\text { Plan }\end{array}$ \\
\hline Hydro energy & $\begin{array}{l}841012 \\
841013 \\
841090\end{array}$ & $\begin{array}{l}\text { Hydraulic turbines \& water wheels, } \\
\text { of a power not }>1000 \mathrm{~kW} \\
\text { Hydraulic turbines \& water wheels, } \\
\text { of a power }>1000 \mathrm{~kW} \text { but not }>10000 \\
\mathrm{~kW} \\
\text { Hydraulic turbines \& water wheels, } \\
\text { of a power }>10000 \mathrm{~kW} \\
\text { Parts (incl. regulators) of the } \\
\text { hydraulic turbines } \\
\& \text { water wheels of } 8410.11-8410.13\end{array}$ & $\begin{array}{l}1 \\
1\end{array}$ \\
\hline Solar thermal & 841919 & $\begin{array}{l}\text { Instantaneous/storage water heaters, } \\
\text { non-electric (excl. of } 8419.11 \text { ) }\end{array}$ & 1 \\
\hline Solar photovoltaic & 854140 & $\begin{array}{l}\text { Photosensitive semiconductor } \\
\text { devices, incl. photovoltaic cells } \\
\text { whether or not assembled in } \\
\text { modules/made up into panels; light } \\
\text { emitting diodes }\end{array}$ & 1 \\
\hline Wind energy & 850231 & $\begin{array}{l}\text { Wind-powered electric generating } \\
\text { sets }\end{array}$ & 1 \\
\hline
\end{tabular}




\begin{tabular}{|c|c|c|c|}
\hline & 730820 & $\begin{array}{l}\text { Towers and lattice masts, of iron or } \\
\text { steel }\end{array}$ & 1 \\
\hline Bioenergy & 840290 & $\begin{array}{l}\text { Steam or other vapour generating } \\
\text { boilers (other than central heating hot } \\
\text { water boilers capable also of producing } \\
\text { low pressure steam); super-heated water } \\
\text { boilers. [Ca, J, NZ, K] }\end{array}$ & 1 \\
\hline Bioenergy & 840410 & $\begin{array}{l}\text { Auxiliary plant for use with boilers } \\
\text { of heading } 84.02 \text { or } 84.03 \text { (for example, } \\
\text { economisers, super-heaters, soot } \\
\text { removers, gas recovers'); condensers for } \\
\text { steam or other vapour power units }\end{array}$ & 1 \\
\hline Bioenergy & 850164 & $\begin{array}{l}\text { AC generators (alternator), of an } \\
\text { output exceeding } 750 \mathrm{kVA}\end{array}$ & 1 \\
\hline $\begin{array}{l}\text { Bioenergy, Ocean, } \\
\text { wave, marine Geothermal } \\
\text { energy }\end{array}$ & 850239 & $\begin{array}{l}\text { Biogas generator sets; Gas } \\
\text { Generator } \\
\quad \text { Small hydro, ocean, geothermal and } \\
\text { biomass gas turbine generating sets. } \\
\text { [US] }\end{array}$ & 1 \\
\hline Smart grids & 902830 & Electricity meters & 2 \\
\hline Energy storage & 850720 & $\begin{array}{l}\text { Lead-acid electric accumulators } \\
\text { except for vehicles }\end{array}$ & 2 \\
\hline $\begin{array}{l}\quad \text { Automatic regulating } \\
\text { or controlling } \\
\text { instruments, other. [Ca, J, } \\
\mathrm{NZ}, \mathrm{K}, \mathrm{Au}, \mathrm{Ru}, \mathrm{BD}]\end{array}$ & 903289 & & 2 \\
\hline Insulation & $\begin{array}{l}680610 \\
680690\end{array}$ & $\begin{array}{l}\text { Slag wool, rock wool \& similar } \\
\text { mineral wools } \\
\text { (incl. intermixtures thereof), in } \\
\text { bulk/sheets/rolls } \\
\quad \text { Mixtures \& articles of heat- } \\
\text { insulating/sound-insulating }\end{array}$ & $\begin{array}{l}3 \\
3\end{array}$ \\
\hline
\end{tabular}




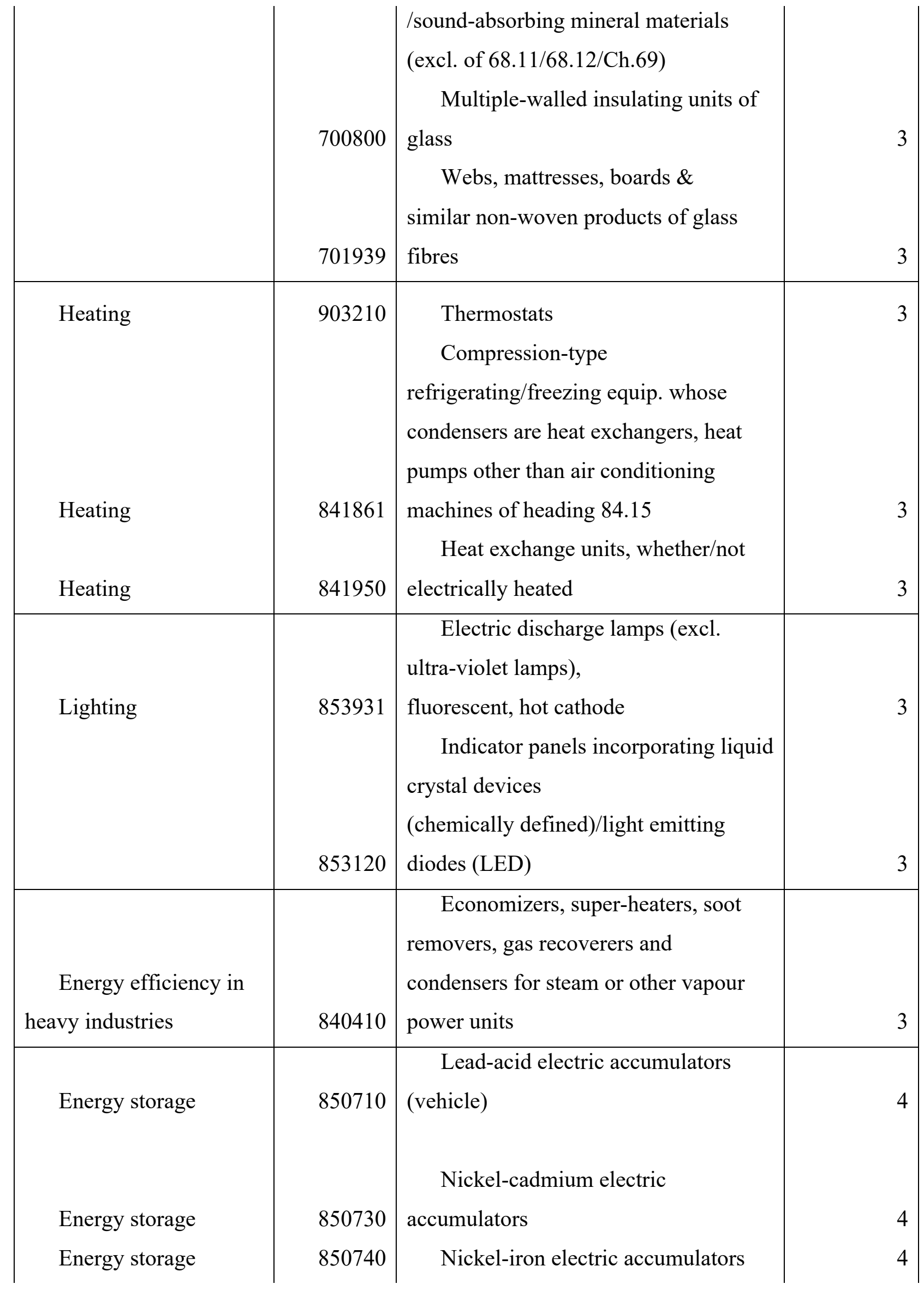




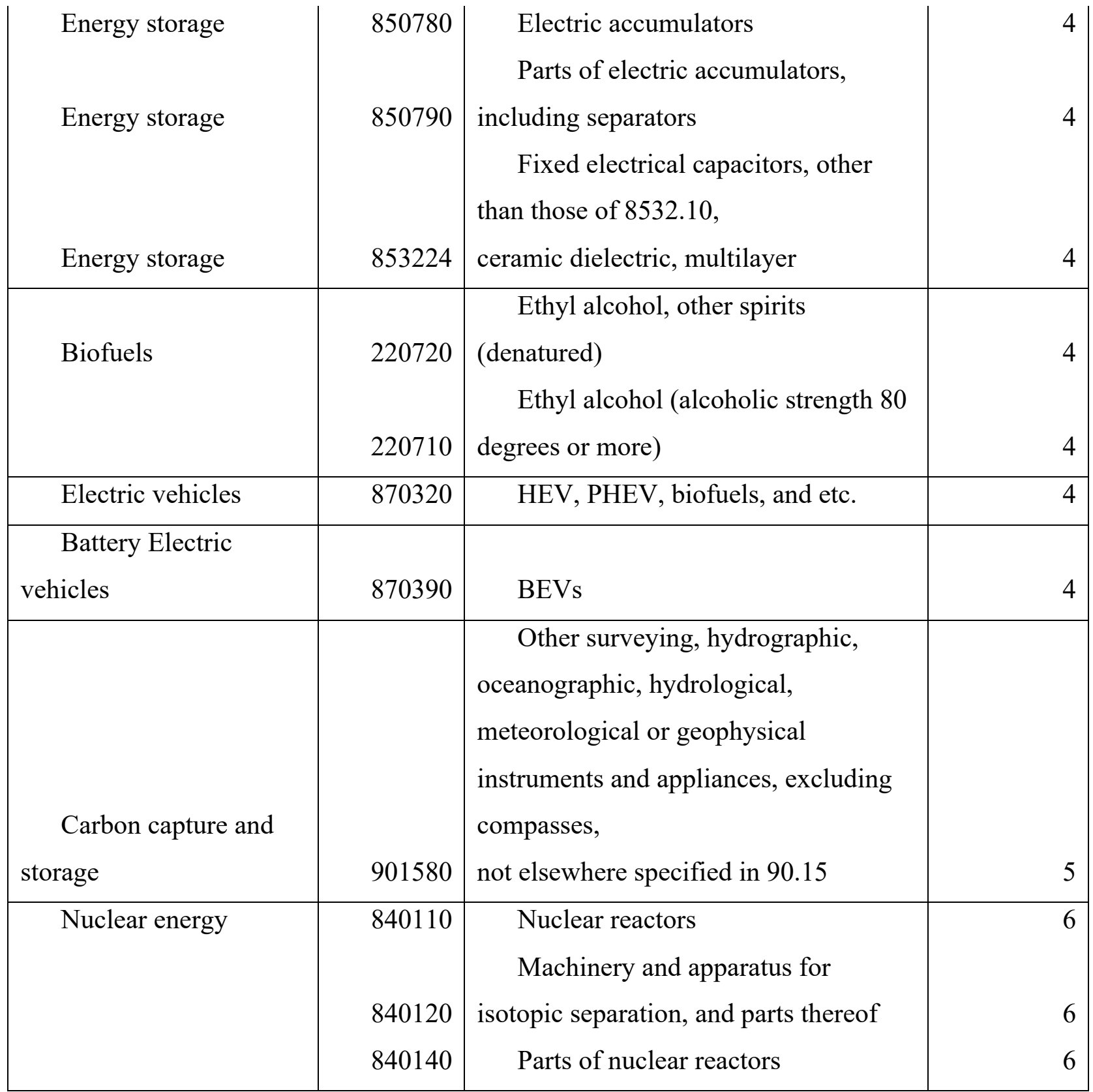

Source:

http:/documents.epo.org/projects/babylon/eponet.nsf/0/6A51029C350D3C8EC1257F110056B93F/\$File/climat e_change_mitigation_technologies_europe_en.pdf

https://www.ictsd.org/downloads/2013/12/info_note_list-of-environmental-goods_sugathan.pdf

http://trade.ec.europa.eu/doclib/docs/2016/may/tradoc_154527.pdf (carbon capture and storage HS code)

http://personal.lse.ac.uk/dechezle/Promoting_the_international_transfer_of_low_carbon_techs.pdf (EE in heavy industry)

http://www.strongandherd.co.uk/files/apeclistof54environmentalgoods.pdf

https://www.researchgate.net/publication/322570116_Intellectual_property_rights_protection_and_the_inte rnational_transfer_of_low-carbon_technologies?enrichId=rgreq-cde75eb28125928f15cd42af22826452XXX\&enrichSource=Y292ZXJQYWdlOzMyMjU3MDExNjtBUzo1ODQ0OTg2MzQ4NDIxMTJAMTUxNjM 2Njc0MjcwNA\%3D\%3D\&el=1_x_2\&_esc=publicationCoverPdf 
Table B8. IEA climate change database STATA do-file

\begin{tabular}{|c|c|}
\hline $\begin{array}{l}\text { SET- } \\
\text { Plan }\end{array}$ & STAT do file \\
\hline 1 & 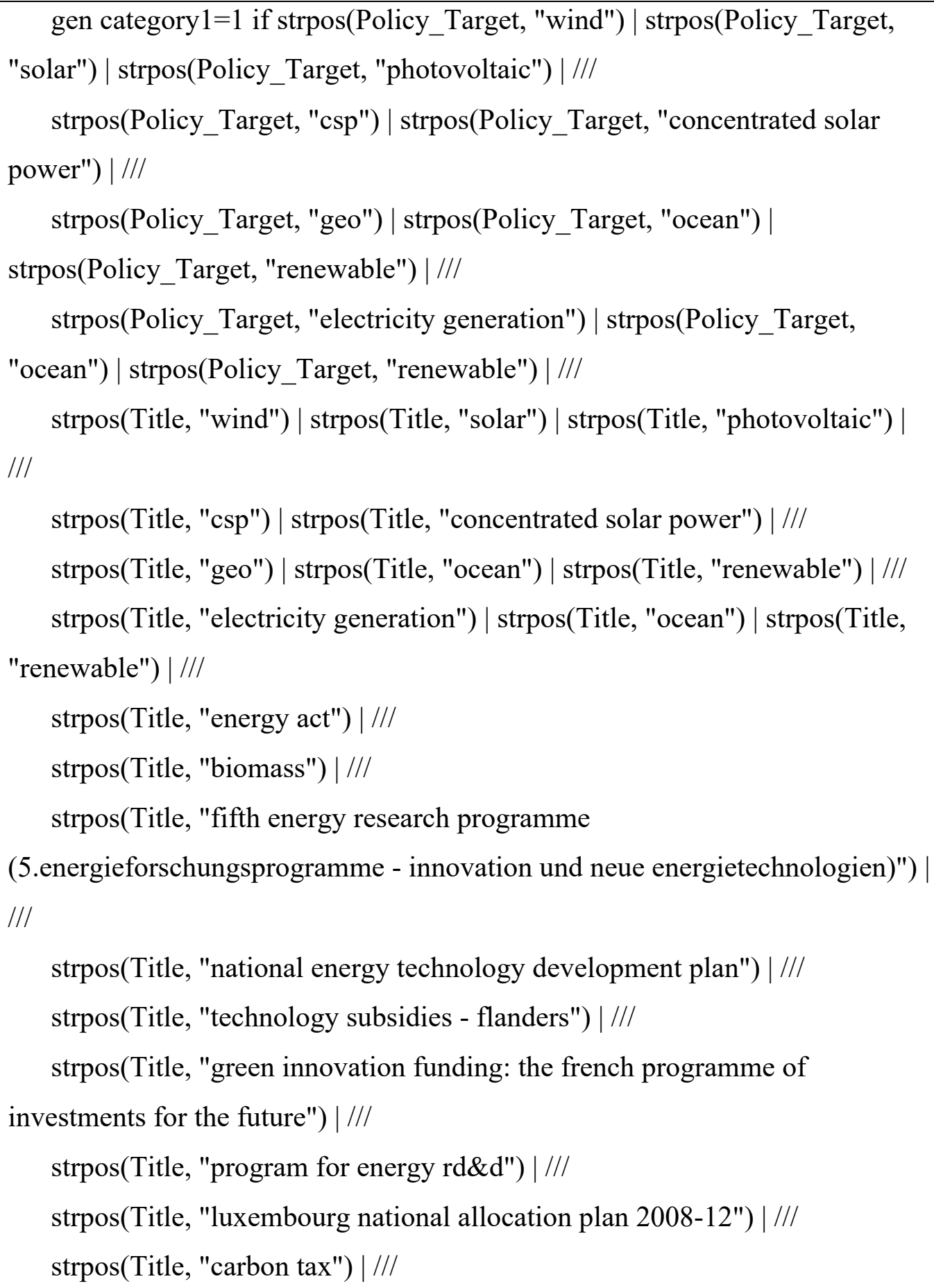 \\
\hline
\end{tabular}




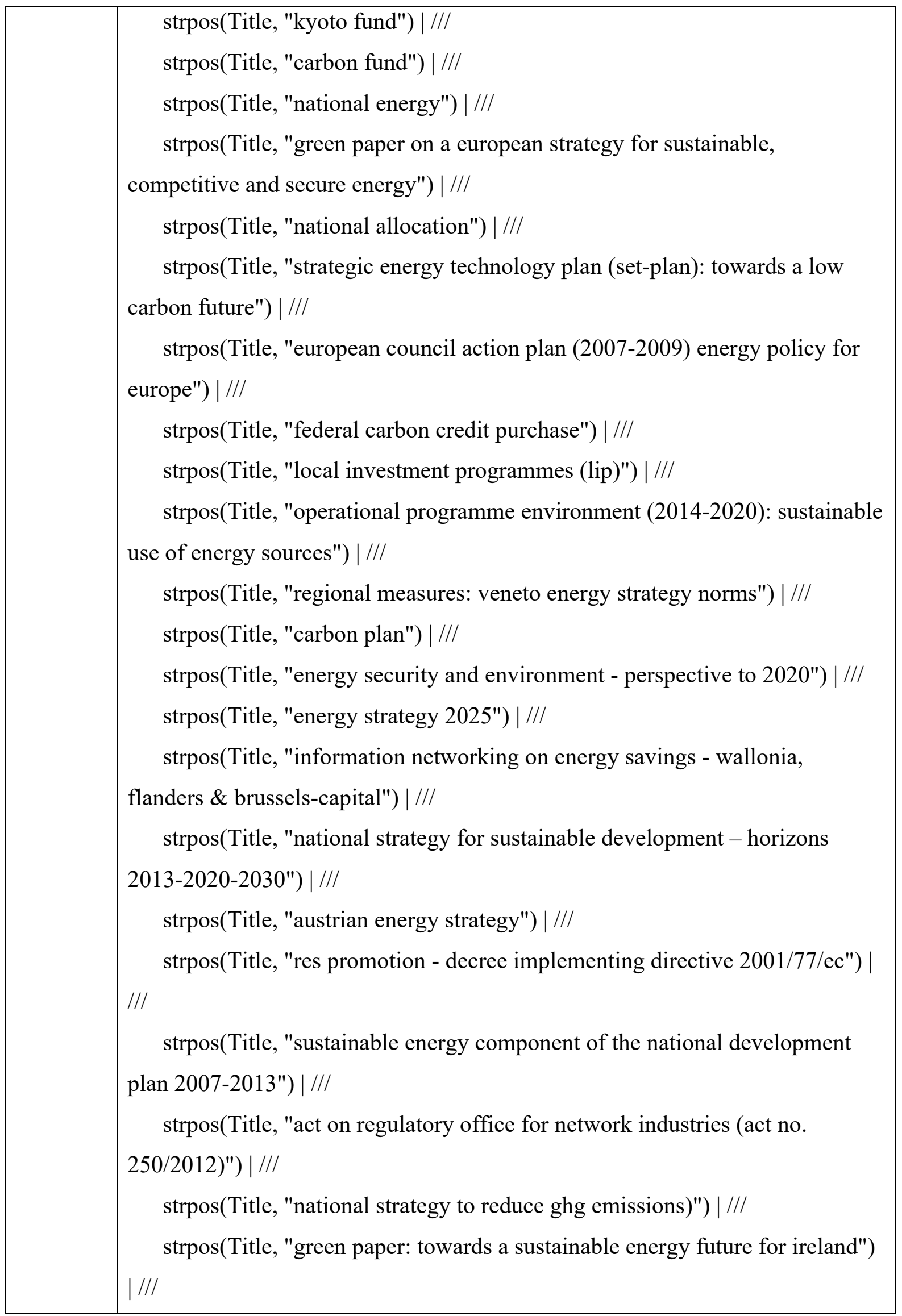




\begin{tabular}{|c|c|}
\hline & $\begin{array}{l}\text { strpos(Title, "survey and pre-feasibility assistance: disposition général des } \\
\text { aides à la décision") |/// } \\
\text { strpos(Title, "energy policy of poland until 2025") |/// } \\
\text { strpos(Title, "national plan on sustainable development") |/// } \\
\text { strpos(Title, "danish energy agreement for 2008-2011") |/// } \\
\text { strpos(Title, "an energy policy for europe") |/// } \\
\text { strpos(Title, "regional rules concerning energy of friuli-venezia-giulia") |/// } \\
\text { strpos(Title, "energy concept") |/// } \\
\text { strpos(Title, "grenelle 1") |/// } \\
\text { strpos(Title, "energy management act (act no. } 406 / 2000 \text { coll.)") |/// } \\
\text { strpos(Title, "national strategy to reduce ghg emissions") }\end{array}$ \\
\hline 2 & $\begin{array}{l}\text { gen category2=1 if strpos(Policy_Target, "storage") | strpos(Policy_Target, } \\
\text { "power") } \mid \text { /// } \\
\text { strpos(Policy_Target, "smart") | strpos(Policy_Target, "grid") | /// } \\
\text { strpos(Policy_Target, "storage") | strpos(Policy_Target, "power") |/// } \\
\text { strpos(Policy_Target, "demand response") | strpos(Policy_Target, } \\
\text { "balancing") | /// } \\
\text { strpos(Policy_Target, "intermittency") | strpos(Policy_Target, "meter") | /// } \\
\text { strpos(Policy_Target, "distribution") | /// } \\
\text { strpos(Title, "storage") | strpos(Title, "power") |/// } \\
\text { strpos(Title, "smart") | strpos(Title, "grid") |/// } \\
\text { strpos(Title, "storage") | strpos(Title, "power") | /// } \\
\text { strpos(Title, "demand response") | strpos(Title, "balancing") | /// } \\
\text { strpos(Title, "intermittency") | strpos(Title, "meter") | /// } \\
\text { strpos(Title, "distribution") |/// } \\
\text { strpos(Title, "energy act") |/// } \\
\text { strpos(Title, "electricity system") | /// } \\
\text { strpos(Title, "demand side") | /// } \\
\text { strpos(Title, "technology subsidies - flanders") |/// } \\
\text { strpos(Title, "green innovation funding: the french programme of } \\
\text { investments for the future") | /// } \\
\text { strpos(Title, "luxembourg national allocation plan 2008-12") |/// }\end{array}$ \\
\hline
\end{tabular}




\begin{tabular}{|c|c|}
\hline & 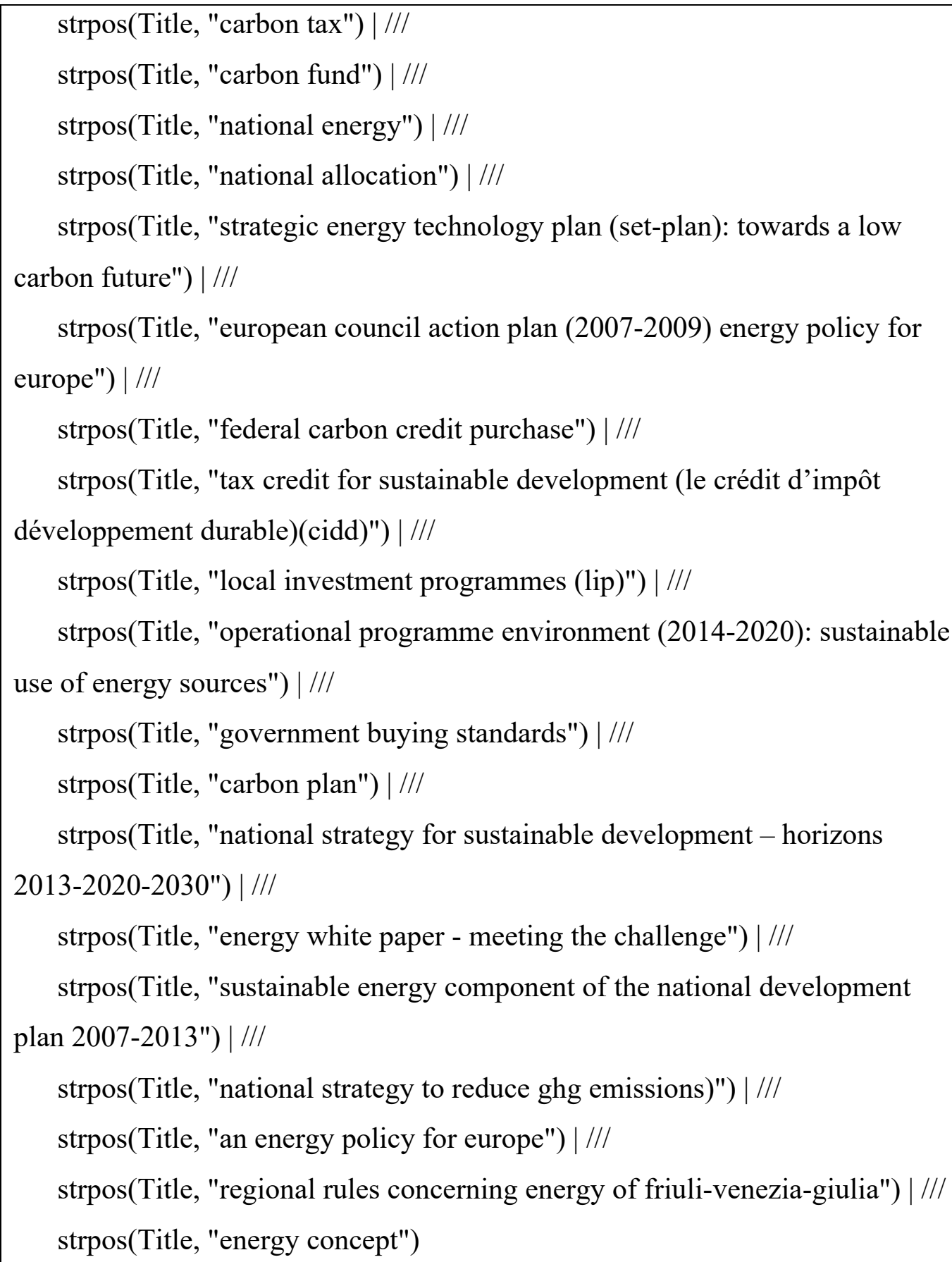 \\
\hline 3 & $\begin{array}{l}\text { gen category3=1 if strpos(Policy_Target, "heating") } \mid \text { strpos(Policy_Target, } \\
\text { "cooling") | strpos(Policy_Target, "energy efficiency") |/// } \\
\text { strpos(Policy_Target, "combined heat and power") | strpos(Policy_Target, } \\
\text { "chp") | strpos(Policy_Target, "appliance") |/// } \\
\text { strpos(Policy_Target, "building") | strpos(Policy_Target, "industry") | } \\
\text { strpos(Policy_Target, "smes") |/// }\end{array}$ \\
\hline
\end{tabular}




\begin{tabular}{|c|}
\hline 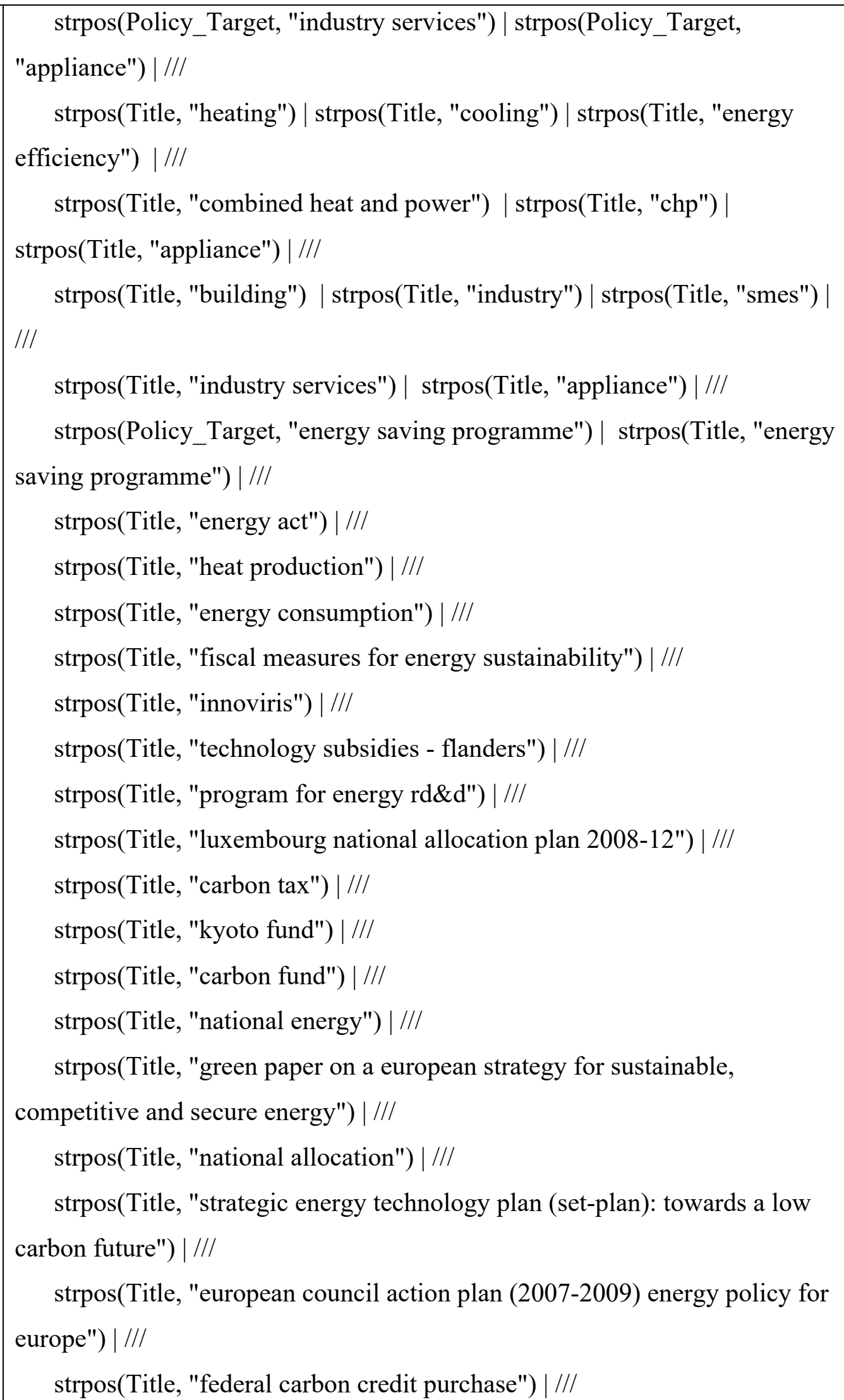 \\
\hline
\end{tabular}




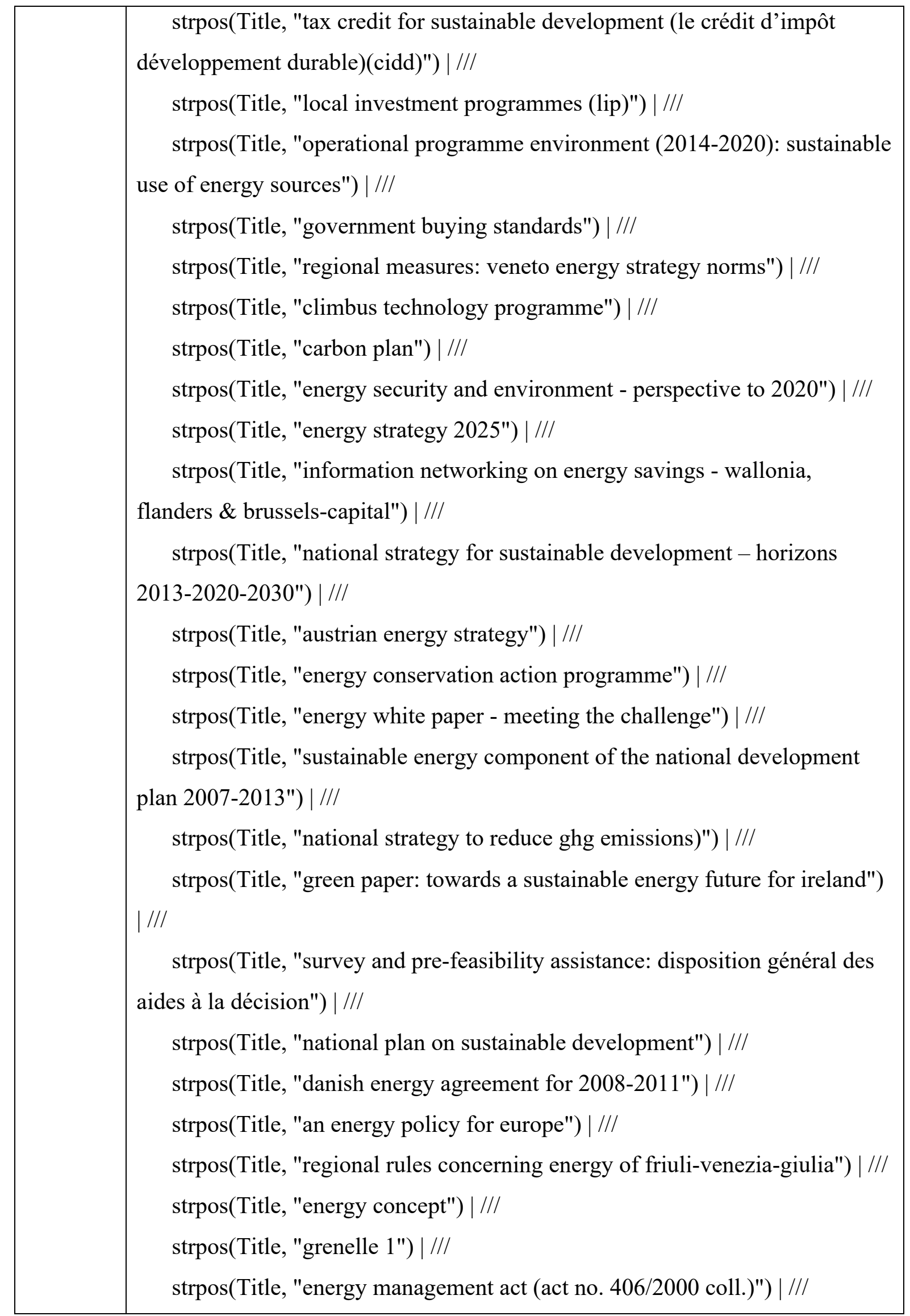




\begin{tabular}{|c|c|}
\hline & $\begin{array}{l}\text { strpos(Title, "innovation clusters") |/// } \\
\text { strpos(Title, "national strategy to reduce ghg emissions") }\end{array}$ \\
\hline 4 & 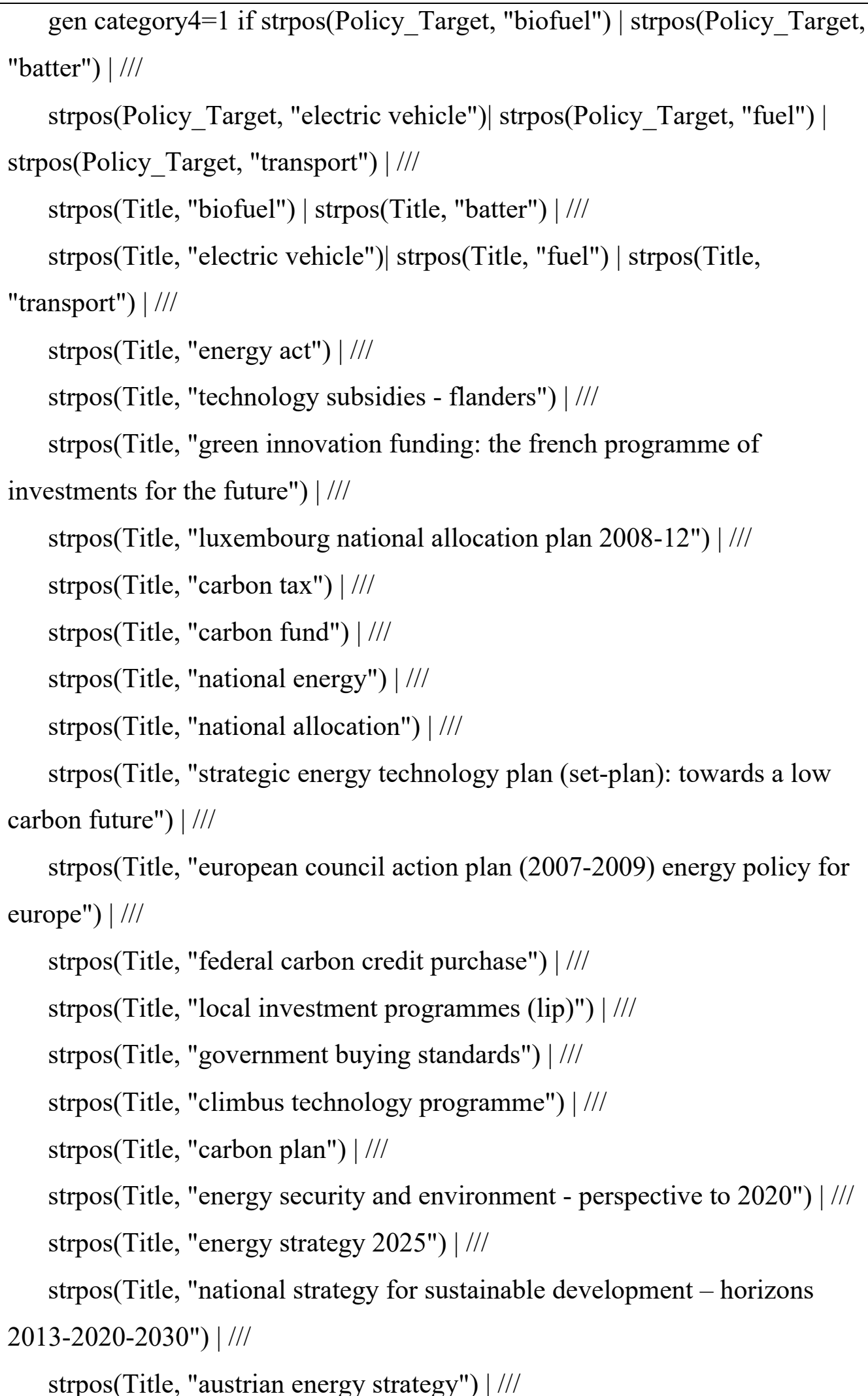 \\
\hline
\end{tabular}




\begin{tabular}{|c|c|}
\hline & $\begin{array}{l}\text { strpos(Title, "sustainable energy component of the national development } \\
\text { plan 2007-2013")|/// } \\
\text { strpos(Title, "national strategy to reduce ghg emissions)") |/// } \\
\text { strpos(Title, "green paper: towards a sustainable energy future for ireland") } \\
\text { |/// } \\
\text { strpos(Title, "energy policy of poland until 2025") |/// } \\
\text { strpos(Title, "national plan on sustainable development") |/// } \\
\text { strpos(Title, "danish energy agreement for 2008-2011") |/// } \\
\text { strpos(Title, "an energy policy for europe") |/// } \\
\text { strpos(Title, "regional rules concerning energy of friuli-venezia-giulia") |/// } \\
\text { strpos(Title, "energy concept") |/// } \\
\text { strpos(Title, "grenelle } 1 \text { ") | /// } \\
\text { strpos(Title, "energy management act (act no. } 406 / 2000 \text { coll.)") |/// } \\
\text { strpos(Title, "national strategy to reduce ghg emissions") }\end{array}$ \\
\hline 5 & $\begin{array}{l}\text { gen category5=1 if strpos(Policy_Target, "carbon capture") | strpos(Title, } \\
\text { "carbon capture") |/// } \\
\text { strpos(Policy_Target, "ccs") | strpos(Title, "ccs") |/// } \\
\text { strpos(Title, "energy act") |/// } \\
\text { strpos(Title, "technology subsidies - flanders") |/// } \\
\text { strpos(Title, "luxembourg national allocation plan 2008-12") |/// } \\
\text { strpos(Title, "carbon tax") |/// } \\
\text { strpos(Title, "carbon fund") |/// } \\
\text { strpos(Title, "national energy")|/// } \\
\text { strpos(Title, "national allocation") |/// } \\
\text { strpos(Title, "strategic energy technology plan (set-plan): towards a low } \\
\text { carbon future") |/// } \\
\text { strpos(Title, "european council action plan (2007-2009) energy policy for } \\
\text { europe") | /// } \\
\text { strpos(Title, "federal carbon credit purchase") |/// } \\
\text { strpos(Title, "carbon plan") |/// } \\
\text { strpos(Title, "national strategy for sustainable development - horizons } \\
2013-2020-2030 ") \mid / / /\end{array}$ \\
\hline
\end{tabular}




\begin{tabular}{|c|c|}
\hline & $\begin{array}{l}\text { strpos(Title, "national strategy to reduce ghg emissions)") |/// } \\
\text { strpos(Title, "an energy policy for europe") |/// } \\
\text { strpos(Title, "regional rules concerning energy of friuli-venezia-giulia") | /// } \\
\text { strpos(Title, "energy concept") }\end{array}$ \\
\hline 6 & $\begin{array}{l}\text { gen category6=1 if strpos(Policy_Target, "nuclear") | strpos(Title, } \\
\text { "nuclear") |/// } \\
\text { strpos(Title, "energy act") |/// } \\
\text { strpos(Title, "technology subsidies - flanders") |/// } \\
\text { strpos(Title, "luxembourg national allocation plan 2008-12") |/// } \\
\text { strpos(Title, "carbon tax") |/// } \\
\text { strpos(Title, "carbon fund") |/// } \\
\text { strpos(Title, "national energy") | /// } \\
\text { strpos(Title, "national allocation") |/// } \\
\text { strpos(Title, "strategic energy technology plan (set-plan): towards a low } \\
\text { carbon future") |/// } \\
\text { strpos(Title, "european council action plan (2007-2009) energy policy for } \\
\text { europe") |/// } \\
\text { strpos(Title, "federal carbon credit purchase") |/// } \\
\text { strpos(Title, "carbon plan") |/// } \\
\text { strpos(Title, "energy security and environment - perspective to 2020") |/// } \\
\text { strpos(Title, "national strategy for sustainable development - horizons } \\
\text { 2013-2020-2030") | /// } \\
\text { strpos(Title, "austrian energy strategy") | /// } \\
\text { strpos(Title, "national strategy to reduce ghg emissions)") | /// } \\
\text { strpos(Title, "regional rules concerning energy of friuli-venezia-giulia") | /// } \\
\text { strpos(Title, "energy concept") }\end{array}$ \\
\hline
\end{tabular}

Table B9. Decay Function Estimation Results

\begin{tabular}{lcccccc}
\hline \multirow{2}{*}{ VARIABLES } & $\mathbf{1}$ & $\mathbf{2}$ & $\mathbf{3}$ & $\mathbf{4}$ & $\mathbf{5}$ & $\mathbf{6}$ \\
\hline \multirow{2}{*}{ time } & $\operatorname{Ln}(\mathbf{R E})$ & $\operatorname{Ln}(\mathbf{S G})$ & $\operatorname{Ln}(\mathrm{EE})$ & $\operatorname{Ln}(\mathbf{S T})$ & $\operatorname{Ln}(\mathbf{C C S})$ & $\operatorname{Ln}(\mathbf{N}$ \\
& - & - & - & - & - & - \\
& 0.000295 & $0.00836^{* * *}$ & $0.00420^{* * *}$ & $0.00253^{* * *}$ & $0.0122^{* * *}$ & $0.0107^{* *}$
\end{tabular}




\begin{tabular}{|c|c|c|c|c|c|c|}
\hline & 0.000846 & 0.000731 & -0.0007 & 0.000674 & 0.000901 & -0.001 \\
\hline \multirow[t]{2}{*}{ Constant } & $4.383 * * *$ & $3.793 * * *$ & $3.754 * * *$ & $3.878 * * *$ & $4.215 * * *$ & $3.297^{\prime}$ \\
\hline & -0.0326 & -0.0473 & -0.0451 & -0.0439 & -0.0517 & -0.086 \\
\hline Observations & 71 & 101 & 104 & 110 & 100 & \\
\hline R-squared & 0.002 & 0.7 & 0.328 & 0.204 & 0.676 & 0.5 \\
\hline
\end{tabular}

Robust standard errors in parentheses

$* * * \mathrm{p}<0.01, * * \mathrm{p}<0.05, * \mathrm{p}<0.1$

Table B10. Estimates of Potential and Actual Market Size in Six SET Plan Priority Areas

[1] Infrastructure - electricity - annual data (MW)

Source: http://appsso.eurostat.ec.europa.eu/nui/show.do?dataset=nrg_113a\&lang=en

[1] onshore wind: \$1661/KW, PV: \$2921/KW (dollar to euros exchange rate:1.1483)

Source: https://www.eia.gov/electricity/generatorcosts/

[1] solar PV actual installed capacity(peak): $94568 \mathrm{MW}$

Source: https://www.eurobserv-er.org/photovoltaic-barometer-2016

[1] Cumulative and annual offshore wind installations: $11073 \mathrm{MW}$

Source: https://windeurope.org/wp-content/uploads/files/aboutwind/statistics/WindEurope-Annual-Offshore-Statistics-2016.pdf

[1] Solar thermal and concentrated solar power barometer 2016: $1861 \mathrm{MW}$

Source: https://www.eurobserv-er.org/solar-thermal-and-concentrated-solar-powerbarometer-2016/

[1] Goethermal: $13.2 \mathrm{GW}$

Source: https://www.worldenergy.org/wpcontent/uploads/2017/03/WEResources_Geothermal_2016.pdf

[1] Ocean 14MW(2016)

Source:

https://setis.ec.europa.eu/sites/default/files/reports/ocean_energy_report_2016.pdf

[2,3] Total number of dwellings, 2011 Census data excluding slovaknia(unavailable)

Source: http://ec.europa.eu/eurostat/web/population-and-housing-census/censusdata/2011-census

[2] Cost of smart metering point $(€ 77-766)$ 
Source: http://eur-lex.europa.eu/legal-

content/EN/TXT/PDF/?uri=CELEX:52014DC0356\&from=EN

[2] The number of smart meter deployment: 110,000,000 numbers

Source: http://www.berginsight.com/reportpdf/productsheet/bi-sm9-ps.pdf

[3] Total number of dwellings, Number of dwellings with EPC(Energy Performance Certificate)(EU Building database)

[3] Euromonitor Passport data(Total number of appliances and average unit retail price)

[3] A weighted average of $\mathrm{A}+++$ rated appliance sales including refrigerators, washing machines, and tumbler drier are based on 2014 data

Source: http://www.topten.eu/uploads/File/WhiteGoods_in_Europe_June15.pdf

[3] Comprehensive improvement(15,000 30,000 Euros per home),

[3] energy efficiency retrofirt(3,800 Euros)

[3] Energy efficiency in buildings: Transforming the market

Source:

http://isites.harvard.edu/fs/docs/icb.topic539148.files/WBCSD\%20Green\%20Construction.p $\mathrm{df}$

[4] Passenger cars, by type of motor energy and size of engine(Eurostat)

Source:

http://appsso.eurostat.ec.europa.eu/nui/show.do?dataset=road_eqs_carmot\&lang=en

[4] Electric vehicles in Europe: 149,500

Source: European Environment Agency

[4] Average price of electric vehicles: 32,500 Euros

Source: http://www.theicct.org/sites/default/files/publications/ICCT_EUpocketbook_2015.pdf

[5] Infrastructure - electricity - annual data (MW)

Source: http://appsso.eurostat.ec.europa.eu/nui/show.do?dataset=nrg_113a\&lang=en

[5] Rubin (2015)

Source:

http://www.cmu.edu/epp/iecm/rubin/PDF\%20files/2015/Rubin_et_al_ThecostofCCS_IJGGC 2015.pdf

[5] CCS current projects in Europe(Sleipner CO2 Storage Project and Snøhvit CO2 Storage Project: 500+100 MW)

Source: https://www.globalccsinstitute.com/projects/large-scale-ccs-projects 
[5] CCS unit costs: Total capital reqm't with capture(2,561,875 USD/kW)

Source: http://hub.globalccsinstitute.com/publications/cost-carbon-capture-and-storagedemonstration-projects-europe/5-cost-european-ccs-demonstration-programme

Source:

http://www.cmu.edu/epp/iecm/rubin/PDF\%20files/2015/Rubin_et_al_ThecostofCCS_IJGGC _2015.pdf

[6] Infrastructure electricity annual data: 3,653,490 Euros/MW

*While more than 20 small-scale demonstration CCS projects are operating globally, none of these are in the EU

Source: https://ec.europa.eu/energy/en/topics/oil-gas-and-coal/carbon-capture-and-storage

Source: http://appsso.eurostat.ec.europa.eu/nui/show.do?dataset=nrg_113a\&lang=en

http://www.rff.org/files/sharepoint/WorkImages/Download/RFF-BCK-Rothwell-

Nuclear.pdf

\section{References}

Belter, C. W., \& Seidel, D. J. (2013). A bibliometric analysis of climate engineering research. WIREs Clim Change, 4(October), 417-427. https://doi.org/10.1002/wcc.229

Cindrella, L., Fu, H., \& Ho, Y. (2017). Global thrust on fuel cells and their sustainability - an assessment of research trends by bibliometric analysis. International Journal of Sustainable Energy, 6451(June). https://doi.org/10.1080/14786451.2012.755185

Haščič, I., \& Migotto, M. (2015). Measuring environmental innovation using patent data, (89), 59. https://doi.org/10.1787/5js009kf48xw-en

Hu, R., Skea, J., \& Hannon, M. (2017). Measuring the effectiveness of energy innovation systems: an indicator framework and a case study. Technological Forecasting and Social Change.

Nilsson, M., \& Nykvist, B. (2016). Governing the electric vehicle transition ??? Near term interventions to support a green energy economy. Applied Energy, 179, 1360-1371. https://doi.org/10.1016/j.apenergy.2016.03.056

Popp, D. (2015). Government R\&D Spending : The Case of Energy (No. 5442).

Popp, D. (2016). From Science to Technology: The Value of Knowledge From Different Energy Research Institutions (No. 22573). Retrieved from http://www.nber.org/papers/w22573

Rizzi, F., van Eck, N. J., \& Frey, M. (2014). The production of scientific knowledge on 93 
renewable energies: Worldwide trends, dynamics and challenges and implications for management. Renewable Energy, 62, 657-671.

https://doi.org/10.1016/j.renene.2013.08.030

Rubin, E. S., Azevedo, I. M. L., Jaramillo, P., \& Yeh, S. (2015). A review of learning rates for electricity supply technologies. Energy Policy, 86, 198-218.

https://doi.org/10.1016/j.enpol.2015.06.011

Sanz-Casado, E., Lascurain-Sánchez, M. L., Serrano-Lopez, A. E., Larsen, B., \& Ingwersen, P. (2014). Production, consumption and research on solar energy Sanz-Casado,. Renewable Energy, 68, 733-744. https://doi.org/10.1016/j.renene.2014.03.013

Stojkoska, B. L. R., \& Trivodaliev, K. V. (2016). A review of Internet of Things for smart home: Challenges and solutions. Journal of Cleaner Production.

Tsay, M.-Y. (2008). A bibliometric analysis of hydrogen energy literature , $1965-2005$. Scientometrics, 75(3), 421-438. https://doi.org/10.1007/s11192-007-1785-X

Weiss, M., Patel, M. K., Junginger, M., \& Blok, K. (2010). Analyzing price and efficiency dynamics of large appliances with the experience curve approach. Energy Policy, 38(2), 770-783. https://doi.org/10.1016/j.enpol.2009.10.022

Yesil-Celiktas, O. (2014). Patenting trends in enzyme related microfluidic applications. Biochemical Engineering Journal, 92, 53-62. https://doi.org/10.1016/j.bej.2014.06.017 


\section{Appendix C. Variability between early and late stage innovation system processes.}

The middle and right panels of Figure $\mathrm{C} 1$ show variability in the relative emphasis of early stage innovation system processes (middle panels) and late stage innovation system processes (right panels) within each ETIS dimension. If inconsistency were the result of early stage processes being grouped with dominant late stage processes for a more mature technology field (e.g., energy efficiency), or late stage processes being grouped with dominant early stage processes for an emerging technology field (e.g., sustainable transport), then variability observed in the left panels of Figure $\mathrm{C} 1$ should collapse when distinguished between early and late stage processes. This is not the case, so we reject this explanation, although it should be noted that as we characterised most knowledge-related processes as early stage, this is unlikely to help explain the main inconsistencies observed.

- Knowledge dimension (10).

Early stage (9): public energy RD\&D expenditure, demonstration budgets, publications, citation-weighted publication counts, patents, citation-weighted patent counts, publication co-authorship (intra-extra), patent co-inventions (intra-extra) and volatility in energy RD\&D expenditure Late stage (1): energy technology imports

- Resources \& Policies dimension (12).

Early stage (8): public energy RD\&D expenditure as \% of GDP, Top 100 Clean-tech funds, patent activity as \% of total patents, policy density (innovation), policy durability (innovation), diversity of policy instruments, stability of policy instruments, public RD\&D expenditure on fossil fuels Late stage (7): Top 100 Clean-tech funds, policy density (regulatory), policy density (market-based), policy durability (regulatory), policy durability (marked-based), diversity of policy instruments, stability of policy instruments

- Actors \& Networks dimension (9).

Early stage (8): diversity of types of organisation in publication activity, diversity of types of organisation in patenting activity, diversity of types of organisation in research collaborations, publication co-authorship (intra-extra), patent co-inventions (intra-extra), research collaborations (intra-extra), policy target density, policy target durability

Late stage (5): diversity of types of organisations in research collaboraitons, research collaborations (intra-extra), policy target density, policy target durability, decline in interest following a failure 


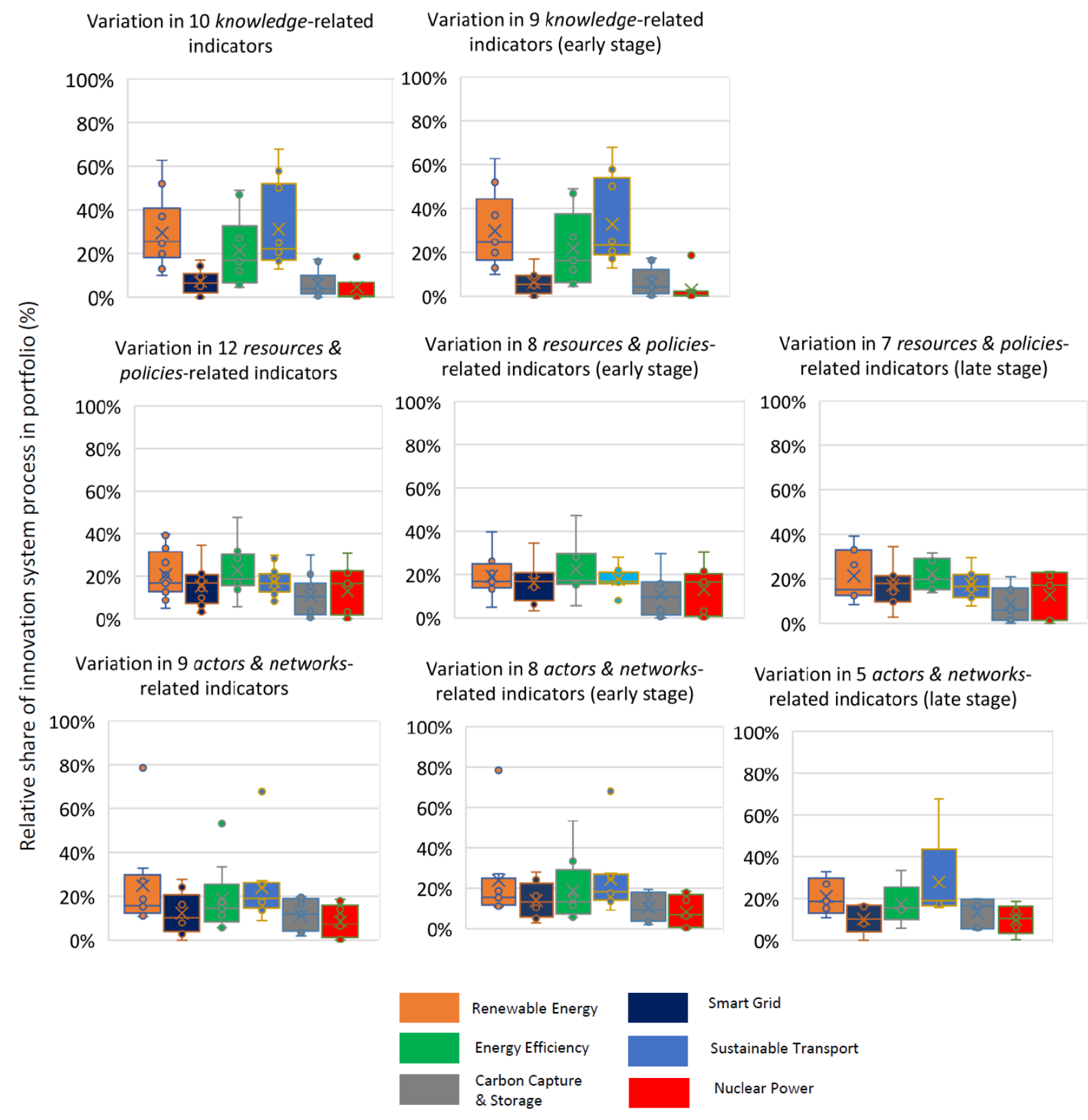

Figure C1. Relative shares of early and late stage innovation system processes in each ETIS dimension for the six technology fields in the EU SET Plan using 2015 data. Note: o indicate data points with X as mean, median; box shows second \& third quartiles separated by line; whiskers show first \& fourth quartiles. 